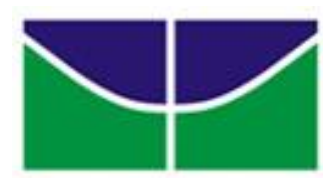

Universidade de Brasília

Faculdade de Educação

Programa de Pós-Graduação em Educação

Mestrado Profissional em Educação

Área de Gestão de Políticas e Sistemas Educacionais

JOSÉ RICARDO ALBERNÁS LIMA

QUALIDADE E/OU IDEOLOGIA? CONEXÕES ENTRE O PNLD E O LIVRO DIDÁTICO DE HISTÓRIA.

Brasília, dezembro de 2015 


\section{$\longrightarrow$ \\ JOSÉ RICARDO ALBERNÁS LIMA}

\section{QUALIDADE E/OU IDEOLOGIA? CONEXÕES ENTRE O PNLD E O LIVRO DIDÁTICO DE HISTÓRIA.}

Dissertação de Mestrado Profissional apresentada ao Programa de Pós-graduação em Educação da Faculdade de Educação da Universidade de Brasília, vinculada à linha de pesquisa em Gestão de Políticas e Sistemas Educacionais, como exigência parcial para obtenção do título de Mestre em Educação, sob orientação da Prof ${ }^{a}$ Dra. Renísia Cristina Garcia.

\section{Brasília}

Dezembro de 2015 


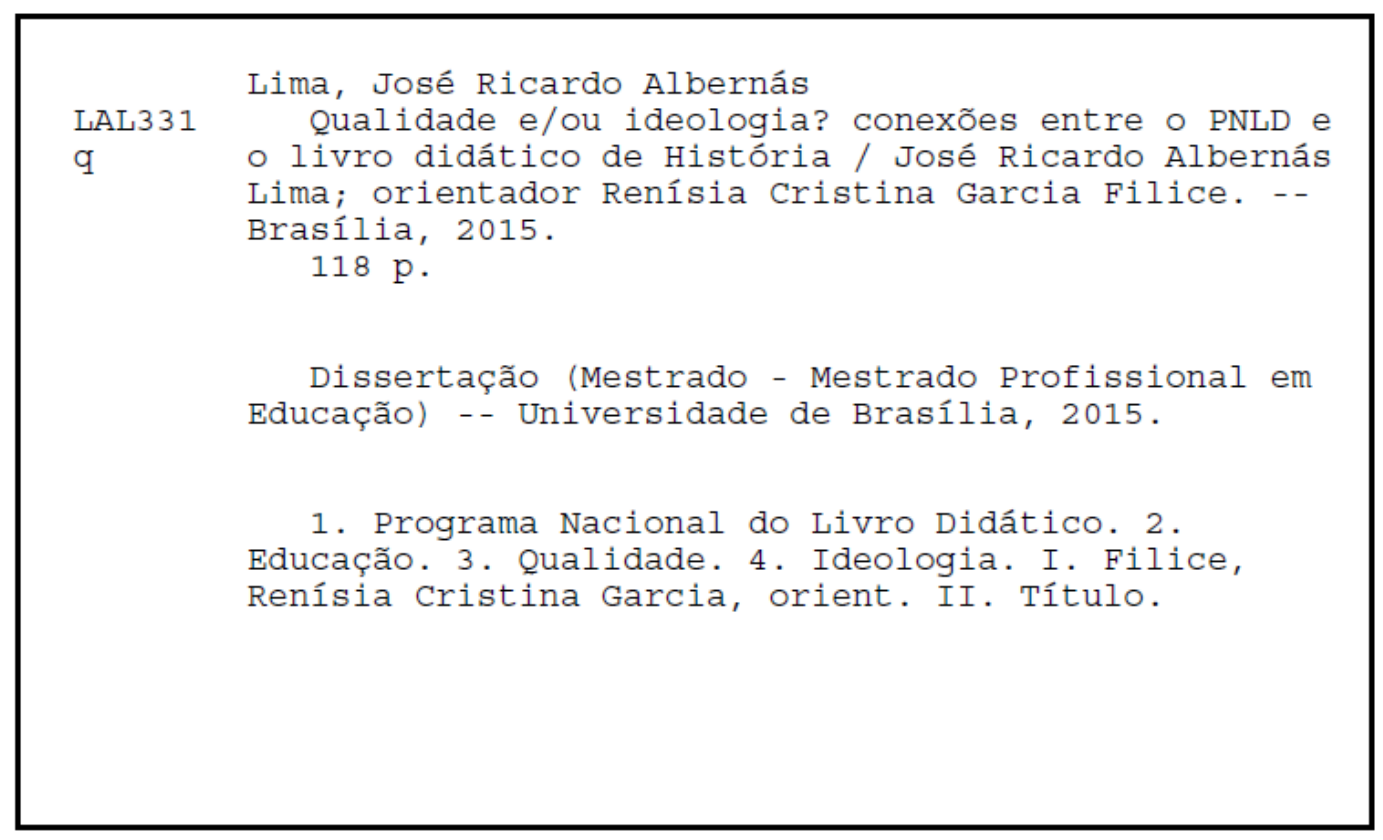




\title{
QUALIDADE E/OU IDEOLOGIA? CONEXÕES ENTRE O PROGRAMA NACIONAL DO LIVRO DIDÁTICO E O LIVRO DIDÁTICO DE HISTÓRIA.
}

\begin{abstract}
Dissertação de Mestrado Profissional apresentada ao Programa de Pós-graduação em Educação da Faculdade de Educação da Universidade de Brasília, vinculada à linha de pesquisa em Gestão de Políticas e Sistemas Educacionais, como exigência parcial para obtenção do título de Mestre em Educação, sob orientação da Prof ${ }^{a}$ Dra. Renísia Cristina Garcia.
\end{abstract}

Brasília, 14 de dezembro de 2015.

\begin{abstract}
Comissão Examinadora
Professora Dra. Renísia Cristina Garcia Filice

Orientadora - FE/UnB

Professor Dr. Anderson Ribeiro Oliva

Examinador externo - IH-HIS/UnB
\end{abstract}

Professora Dra. Shirleide Pereira da Silva Cruz

Examinadora interna - FE/UnB

Professora Dra. Maria da Conceição da Silva Freitas

Suplente - FE/UnB 


\section{AGRADECIMENTOS}

À professora e orientadora Renísia Cristina Garcia Filice, meu respeito e reconhecimento pela competência e paciência com que me orientou e partilhou comigo parte de seus conhecimentos os quais foram fundamentais para a realização deste estudo e para o meu crescimento acadêmico.

Aos professores que compuseram a banca, professora Shirleide Pereira da Silva Cruz e professor Anderson Ribeiro Oliva que, na qualificação e na defesa, apresentaram valiosas contribuições para o processo de construção desta pesquisa.

Aos colegas do Programa de Pós-Graduação em Educação, pela companhia e camaradagem nas aulas, nos trabalhos em grupos e na troca de ideias, especial a Juliana, Eduardo e Amanda. Aos colegas de trabalho em especial aos lotados na Coordenação-Geral de Materiais Didáticos da Secretaria de Educação Básica do Ministério da Educação. Não me esquecerei do apoio das minhas ex-colegas e grandes amigas de Coordenação Andrea Kluge e Lunalva da Conceição Gomes. Aos professores avaliadores que responderam ao questionado enviado, bem como à professora Maria Inês Sucupira Stamatto pela inestimável ajuda junto ao polo de avaliadores da Universidade Federal do Rio Grande do Norte.

À minha família e amigos pela força e o contínuo incentivo. Um agradecimento especial à Mariana Kopsch pelo incentivo na reta final desta jornada.

Sem vocês não conseguiria realizar este trabalho e concretizar esta jornada.

Muito obrigado! 
TÍTULO: Qualidade e/ou Ideologia? Conexões entre o Programa Nacional do Livro Didático e o Livro Didático de História

\section{RESUMO}

Este estudo tem como objeto o Programa Nacional do Livro Didático (PNLD), mais especificamente o processo de avaliação pedagógica de livros didáticos de História para os Anos Finais do Ensino Fundamental. A partir dos Editais do referido programa, busca entender se há uma orientação ideológica no livro de história que possa ser associada ao PNLD, bem como, analisar se os editais atendem aos ditames legais pertinentes à área de educação. Para tanto, autores como Marx (1846), Chaui (2004), Brandão e Dias (2007), Demo (1994) e Gentili (2007) nos ajudaram a problematizar os conceitos de qualidade e de ideologia em perspectiva com os objetivos declarados no âmbito do Programa Nacional do Livro Didático. O estudo foi realizado por meio de análise de conteúdo dos editais do PNLD correspondentes às etapas dos Anos Finais do Ensino Fundamental nos anos de 2008, 2011 e 2014. Optamos pela pesquisa qualitativa e pelo método dialético a partir de Triviños (2009) e Netto (2011). Os resultados revelam que operam conceitos diferentes de qualidade e ideologia, e que não há como pensar em um programa desta natureza isento de ideologias, enquanto visão de mundo. $\mathrm{O}$ estudo mostrou ainda a necessidade de aperfeiçoamentos na elaboração dos editais do PNLD, bem como mudanças nos processos da avaliação pedagógica do programa.

PAlAVRAS CHAVE: Educação, Qualidade, Ideologia, Programa Nacional do Livro Didático. 
TITLE: Quality or Ideology? Connections between PNLD and the Textbook of History

\begin{abstract}
This paper studied the Programa Nacional do Livro Didático (PNLD), more specifically the pedagogical process of evaluating history textbooks for the Final Years of elementary school. From notices of that program seeks to understand whether there is an ideological guidance in the history book that can be associated with PNLD as well as examine whether the bids meet the relevant legal dictates the education area. To this end, authors such as Marx (1846), Chaui (2004), Brandão and Dias (2007), Demo (1994) and Gentili (2007) aided us to question quality and ideology concepts in perspective to the stated objectives in the National Textbook Program. The study was conducted by content analysis of PNLD notices corresponding to the Final Years stages of primary education in the years 2008, 2011 and 2014. We chose qualitative research and the dialectical method from Triviños (2009) and Netto (2011). The results reveal that operate different concepts of quality and ideology, and there is no way to think of a program of this nature free from ideologies, while worldview. The study also showed the need for improvements in the preparation of PNLD notices, as well as changes in the processes of the program educational evaluation.
\end{abstract}

KEYWORDS: Education, Quality, Ideology, National Textbook Program. 


\section{LISTA DE ABREVIATURAS E SIGLAS}

CEDES Centro de Estudos Educação e Sociedade

CNLD Conselho Nacional do Livro Didático

Cad. Pesqui. Cadernos de Pesquisa

CF Constituição Federal

Cogeam Coordenação-Geral de Materiais Didáticos

Colted Comissão do Livro Técnico e Livro Didático

DCE Diretoria de Formulação de Conteúdos Educacionais

DCN Diretrizes Curriculares Nacionais da Educação Básica

FAE Fundação de Assistência ao Estudante

Fename Fundação Nacional do Material Didático

FNDE Fundo Nacional de Desenvolvimento da Educação

INL Instituto Nacional do Livro

IPT Instituto de Pesquisa Tecnológicas do Estado de São Paulo

LD Livro Didático

LDB Lei de Diretrizes e Base da Educação Nacional

MEC Ministério da Educação

Plidef Programa do Livro Didático para o Ensino Fundamental

PCN Parâmetros Curriculares Nacionais

PNLD Programa Nacional do Livro Didático

PNLEM Programa Nacional do Livro Didático para o Ensino Médio

SciELO Scientific Electronic Library Online

SEB Secretaria de Educação Básica

UFRN Universidade Federal do Rio Grande do Norte

UnB Universidade de Brasília

USAID Agência Norte-Americana para o Desenvolvimento Internacional 


\section{CAPÍTULO 1}

O LIVRO DIDÁTICO EM FOCO: IDEOLOGIA OU QUALIDADE?

1.1 - O estado da arte

1.2 - O processo de avaliação pedagógica

1.3 - O conceito de ideologia e como se apresenta no PNLD

1.4 - O conceito de qualidade da educação

\section{CAPÍTULO 2}

RESULTADOS E ANÁLISE: O EDITAL DO PNLD EM FOCO

2.1 - Percurso teórico-metodológico

\section{CAPÍTULO 3}

CONFRONTOS, ENCONTROS E DESENCONTROS NA POLÍTICA DO LIVRO DIDÁTICO

3.1 Análise dos critérios e princípios estabelecidos nos Editais do PNLD que subsidiam a avaliação pedagógica dos Livros Didáticos no programa

3.2 O Livro Didático segundo o Decreto Lei no 7.084 de 2010 


\section{ANEXOS}

I - Modelo de questionário aplicado

II - Quadro e Tabela sobre os autores de LD aprovados no PNLD 2014

109

REFERÊNCIAS 


\section{LISTA DE QUADROS}

Quadro 1: Percurso Histórico do PNLD

Quadro 2: Processo e estrutura do PNLD

Quadro 3: Processo da avaliação pedagógica

Quadro 4: Percurso da pesquisa 58

Quadro 5: Perfil dos avaliadores 


\section{INTRODUÇÃO}

Este estudo atende à exigência para obtenção do título de mestre do Programa de PósGraduação em Educação (PPGE), Mestrado Profissional, Área de Gestão de Políticas e Sistemas Educacionais da Universidade de Brasília (Unb), e tem como objeto o Programa Nacional do Livro Didático (PNLD), mais especificamente o processo de avaliação pedagógica de livros didáticos de História para os Anos Finais do Ensino Fundamental.

O Ministério da Educação (MEC) executa os Programas Nacionais do Livro e da Leitura que se realizam por meio da abertura de editais públicos através dos quais autores, titulares de direitos autorais e de edição inscrevem obras e conteúdos que, submetidos à avaliação de uma equipe pedagógica multidisciplinar, seguem, sob regulação, para utilização em salas de aula de escolas públicas de educação básica do país e constituição dos acervos de suas bibliotecas. Esses programas são respectivamente o Programa Nacional do Livro Didático (PNLD) e o Programa Nacional Biblioteca da Escola (PNBE).

Os Programas Nacionais do Livro e da Leitura são destinados ao apoio a processos de mediação pedagógica, formação dos profissionais da Educação, bem como produção/circulação e usos de materiais didáticos nas escolas, sendo regulado pelo Decreto $n^{\circ}$ 7.084/2010. Os compromissos históricos dos programas do livro e da leitura, assumidos pelo MEC, historiadores e professores, são a universalização do acesso a materiais didáticos diversificados, a melhoria da qualidade dos livros e materiais distribuídos e utilizados pelas escolas públicas, o aperfeiçoamento dos processos pedagógicos e o apoio à formação docente inicial e continuada.

Neste contexto, o interesse neste nicho nasceu da experiência de trabalho deste pesquisador junto à Coordenação-Geral de Materiais Didáticos (COGEAM) da Secretaria de Educação Básica (SEB) no Ministério da Educação (MEC). Nosso foco será o programa que tem como objeto o Livro Didático (LD), este material está no âmbito do PNLD. Daí ser um estudo de caráter analítico-descritivo e vinculado ao Mestrado do PPGE da UnB.

O estudo visa responder à seguinte questão central: em que medida os livros didáticos de História selecionados e ofertados pelo MEC às escolas públicas do país atende aos ditames legais pertinentes à área de educação, especificamente em relação ao critério qualidade?

Para compreender melhor o processo de análise dessa temática, formulamos uma questão complementar: Os Editais do PNLD são suficientes para garantir os preceitos estabelecidos pelo próprio PNLD, no que se refere à qualidade conforme entendida pelo MEC? 
Dando continuidade à tentativa de compreender esse processo, e como o Ministério da Educação entende o conceito de qualidade que ancora o Programa Nacional do Livro Didático, propomos mais quatro questões:

1- Qual o conceito de qualidade proposto pelo MEC e que se apresenta no PNLD, via Editais?

2- Como a equipe que realiza a avaliação pedagógica das obras no PNLD entende o conceito de qualidade que ancora o PNLD? É o mesmo do MEC?

3- Qual o perfil do avaliador de Livro Didático e dos autores de Livro Didático inscritos no PNLD?

4- De que forma os Editais do PNLD podem ser aprimorados e contribuir para a melhoria do programa, na perspectiva dos avaliadores, e tendo como norte o próprio princípio de qualidade estabelecido pelo MEC?

Este estudo foi realizado por meio de análise de conteúdos dos editais do PNLD. Para tanto, fizemos um recorte que aborda os Editais do PNLD Anos Finais do Ensino Fundamental nos anos de 2008, 2011 e 2014. O recorte abarca os últimos ciclos de avaliação pedagógica neste segmento do PNLD tendo ainda como foco livros didáticos de História selecionados para o triênio.

Atualmente está em andamento o processo avaliativo do PNLD 2017, mas os livros desse ciclo de 2017 só estarão nas escolas no ano de 2017.

Os editais, como o próprio PNLD, têm uma periodicidade fundamentada em ciclos de avaliações. Com o passar dos anos vários editais são elaborados para cada etapa de ensino da educação básica, como o ensino fundamental (anos iniciais e anos finais) e o ensino médio. Estabelece-se, assim, um triênio para que cada obra seja utilizada pelos alunos e depois recolhidas para aquisição de novas e atualizadas obras.

Para melhor entendermos essa política, optamos por utilizar a pesquisa qualitativa segundo Triviños (2009). Como técnica, utilizaremos a análise de conteúdo, por ser um meio que visa estudar as comunicações entre os homens, colocando a ênfase no conteúdo das mensagens escritas e onde a informação surgiria da apreciação objetiva da mensagem (p. 160).

Como método, buscamos inspiração no método dialético, pois este é "capaz de assinalar as causas e as consequências dos problemas, suas contradições, suas relações, suas qualidades [...] e realizar através da ação um processo de transformação da realidade que interessa" (TRIVIÑOS, 2009, p. 125). Essa inspiração em um método dialético no viés marxista em um sentido de processo, movimento que se dinamiza por contradições, o objeto como um conjunto de processos conforme nos esclarece Netto (2011, p. 31) Ao aplicar essa metodologia, 
considera-se "o contexto do fenômeno social que se estuda, privilegia a prática e o propósito transformador do conhecimento que se adquire da realidade que se procura desvendar em seus aspectos essenciais e acidentais" (TRIVIÑOS, 2009, p.125).

\section{I - Relevância do tema}

O Livro Didático é orientado para uso pedagógico na escola. Assim, possui um caráter diferente dos livros clássicos e literários, sendo considerado uma importante ferramenta para o trabalho do professor em sala de aula, quando não a principal.

No Brasil, sua distribuição com caráter sistemático e como ação do Estado teve início no século XX. Com a criação do Ministério da Educação (1930), o Estado estabelece a necessidade de o poder público assumir essa demanda social por uma educação pública voltada para todos os cidadãos. Para consolidar essa ação, cabe ao Estado garantir, além da estrutura a escola, os profissionais da educação destacando-se o professor, em particular, e o material a ser utilizado em sala de aula, daí a importância do Livro Didático.

Em 1936 houve um projeto de Plano Nacional de Educação que previa assistência aos alunos necessitados de fornecimento gratuito de material escolar, de livros didáticos, no caso, indicados pelos respectivos professores. Ainda na Era Vargas (1930-1945) na gestão do Ministro Gustavo Capanema se deu a criação do Instituto Nacional do Livro.

Em 1972 houve o Plano Setorial de Educação e Cultura (PSEC), consequente ao Plano Nacional de Desenvolvimento (1 PND), ao estabelecer diretrizes para os programas do livro didático, insistia no acesso e na qualidade do livro didático como instrumento eficiente de comunicação e ação pedagógica. (PARECER CEB nº: 15/2000).

A despeito das idas e vindas do cenário político brasileiro, e consequentemente do cenário das políticas em educação do país, o LD passou a ser uma preocupação nas ações a serem implementadas pelo Estado. Com a redemocratização, a partir de 1985, novos caminhos para as políticas públicas em educação ganhariam o contorno de atender às demandas sociais que eclodiriam na década de 90 e atingindo grande visibilidade no início do século XXI.

O Programa Nacional do Livro Didático que, instituído pelo Decreto-Lei no 91.542 , de 19 de agosto de 1985, “estabeleceu e fixou parte das características atuais do PNLD: adoção de livros reutilizáveis (exceto para a $1^{\mathrm{a}}$ série), escolha do livro pelo conjunto de professores, sua distribuição gratuita às escolas e sua aquisição com recursos do Governo Federal.” (BATISTA, 2011, p. 11). De forma gradativa, o programa buscou a universalização da distribuição do livro 
didático no ensino fundamental e, em andamento, é o mais antigo dos programas voltados à distribuição de obras didáticas aos estudantes da rede pública de ensino brasileira.

O processo de avaliação e distribuição das obras didáticas no âmbito do PNLD é executado pela Secretaria da Educação Básica, que coordena o trabalho de avaliação pedagógica das obras inscritas em parceria com instituições públicas de ensino superior e com o Fundo Nacional de Desenvolvimento da Educação (FNDE). Após a avaliação e escolha feita pelos professores, cabe ao FNDE a aquisição e distribuição das obras selecionadas às escolas públicas.

A primeira avaliação ocorreu no ano de 1995 , referente aos livros da $1^{\mathrm{a}}$ à $4^{\mathrm{a}}$ série, sendo a distribuição garantida financeiramente no ano seguinte pelo FNDE, segundo Batista:

Até então, o envolvimento do MEC com o livro didático vinha se limitando, por meio da Fundação de Assistência ao Estudante (FAE) - executor do Programa Nacional do Livro Didático até a extinção do órgão, em 1997 -, à aquisição e à distribuição gratuita dos livros didáticos escolhidos pelos professores e encaminhados às escolas. Embora a compra desses livros sempre envolvesse volumes e cifras de grande monta (...) em nenhum momento o Ministério vinha se propondo, direta e sistematicamente, a discutir a qualidade e a correção dos livros que adquiria e que buscava fazer chegar às mãos dos alunos e professores das escolas públicas do ensino fundamental. (BATISTA, 2011, p. 11).

Uma década depois da proposição da política, a partir de 1995, as obras adquiridas e distribuídas passaram a ser avaliadas de acordo com os critérios estabelecidos pelo MEC. Os critérios que excluíam o LD no programa foram:

- Os livros não podem expressar preconceitos de origem, raça, sexo, cor, idade e quaisquer outras formas de discriminação.

- Os livros não podem conter ou induzir a erros graves relativos ao conteúdo da área, como, por exemplo, erros conceituais.

(MEC, PNLD, 1997)

Ao longo dos anos, esses critérios foram sendo aprimorados, mantendo-se o rigor com relação à ausência de preconceitos e discriminação e de erros conceituais.

O PNLD tornou-se, com o passar dos anos, um importante vetor na política pública de educação, além de sua função precípua de fornecer material didático aos alunos, também funcionando, muitas vezes, como "conteúdo curricular" em sala de aula, como "ferramenta" para formação continuada do professor, e claro, também, como grande fonte de recursos para o 
mercado editorial brasileiro. Esse conjunto de questões pela origem contraditória - educação e mercado - será problematizado mais à frente.

Nesse contexto, para melhor entender a relação entre o documento balizador do PNLD - o edital, o mercado editorial e o livro didático, uma questão imediata pode ser pertinente: é certo que o livro didático traz, por sua proposta editorial e pela própria seleção dos conteúdos e abordagem, uma concepção de educação, de ensino, de docente, de aluno, de sociedade e de escola. Os editais que regem o PNLD têm, em princípio, a proposta de levar aos alunos e professores obras livres de doutrinações políticas ideológicas.

Outro fator motivador são as últimas investidas sobre a Coordenação-Geral de Materiais Didáticos, da Secretaria de Educação Básica (SEB/MEC) questionando a aprovação de certos Livros Didáticos de História que estariam a propagar conteúdo político ideológico de esquerda. ${ }^{1}$

O Programa Nacional do Livro Didático sofre questionamentos por parte da sociedade, em parte, devido ao grande impacto que o Programa exerce sobre o sistema público de ensino do país. Pessoas, assim como este pesquisador também técnico do MEC, que trabalham diretamente com o PNLD percebem a necessidade de uma resposta institucional aos questionamentos feitos a respeito de possíveis falhas ou omissões no processo de avaliação e de seleção de obras didáticas. No caso específico da disciplina História, a ofensiva é maior e fica mais patente, pois frequentemente as diferentes abordagens, próprias deste campo de estudo, a história, podem ser confundidas e vistas como influências de cunho político e ideológico, causando uma grande confusão. Evidenciar e separar o que é do campo teórico é uma das ações entendidas como necessárias para minimizar os conflitos.

Nesse sentido, é preciso saber como foi o processo de avaliação das obras didáticas, ao longo dos anos de execução do PNLD, e quais os mecanismos de controle adotados. Daí, veremos se as avalições do PNLD garantem que as obras de História estejam isentas de propaganda ideológica e de cunho político como tem sido acusado o PNLD, bem como se as prerrogativas contidas nos editais do programa são eficazes nesse aspecto e se são cumpridas.

\footnotetext{
${ }^{1}$ A SEB/MEC recebe diversas manifestações contestatórias de particulares ou institucionais, ações movidas em Ministérios Públicos Estaduais acerca dos LD selecionados e distribuídos às escolas públicas. Essas ações são oriundas de movimentos organizados de militares da reserva do exército ou de pais, por exemplo.
} 


\section{II- Uma história, e um livro didático "neutro", existem?}

O livro didático, e o livro didático de História em particular, tem sido objeto de constantes debates, pesquisas e contestações no meio acadêmico e fora dele. São inúmeras as manifestações a favor e contra o livro didático. Ouve-se e lê-se, comumente, que o livro didático é "conteudista", que "reforça a ideologia dominante", que "retira a autonomia do professor." Os que mais advogam nesse sentido têm sido os jornalistas.

O jornalista Ali Kamel do Jornal O Globo em matéria de 18 de setembro de 2007, “O que ensinam às nossas crianças", acusa o MEC de distribuir livro didático com caráter ideológico de esquerda:

Não vou importunar o leitor com teorias sobre Gramsci, hegemonia, nada disso. Ao fim da leitura, tenho certeza de que todos vão entender o que se está fazendo com as nossas crianças e com que objetivo. O psicanalista Francisco Daudt me fez chegar às mãos o livro didático "Nova História Crítica, $8^{\mathrm{a}}$ série" distribuído gratuitamente pelo MEC a 750 mil alunos da rede pública. O que ele leu ali é de dar medo. Apenas uma tentativa de fazer nossas crianças acreditarem que o capitalismo é mau e que a solução de todos os problemas é o socialismo, que só fracassou até aqui por culpa de burocratas autoritários. [...] De que forma nossas crianças poderão saber que Mao foi um assassino frio de multidões? Que a Revolução Cultural foi uma das maiores insanidades que o mundo presenciou, levando à morte de milhões? Que Cuba é responsável pelos seus fracassos e que o paredão levou à morte, em julgamentos sumários, não torturadores, mas milhares de oponentes do novo regime? E que a URSS não desabou por sentimentos de inveja, mas porque o socialismo real, uma ditadura que esmaga o indivíduo, provou-se não um sonho, mas apenas um pesadelo? Nossas crianças estão sendo enganadas, a cabeça delas vem sendo trabalhada, e o efeito disso será sentido em poucos anos. É isso o que deseja o MEC? Se não for, algo precisa ser feito, pelo ministério, pelo congresso, por alguém (KAMEL, 2007).

O debate ideológico na imprensa em torno do livro didático de História não se restringe a este, que atualmente é diretor de uma grande rede de televisão no Brasil, mas envolve outros articulistas. Alguns contrapõem os posicionamentos liderados pelo jornalista Kamel, a exemplo do também jornalista Luis Nassif. Ele faz um contraponto em artigo de 21 de setembro de 2007 visto que o caráter ideológico contido na crítica de Kamel ao livro "Nova História Crítica" não lhe passou despercebida, bem como a utilização política do mesmo também. Nesse caso, ele faz a crítica a Kamel e evidencia a normatização do processo de elaboração e escolha de livros de história por ser uma política de Estado:

A guerra ideológica continua produzindo uma vítima recorrente: a notícia. Digo isso a propósito do artigo de Ali Kamel em "O Globo", reproduzido no 
"Estadão", desancando o livro "Nova História Crítica, 8a série" - acusado por ele de doutrinação comunista, e denunciando o MEC (Ministério da Educação) de distribuí-lo gratuitamente. A denúncia repercutiu na imprensa mundial, de "El Pais", na Espanha, ao "Miami Herald", nos Estados Unidos. Na verdade o livro foi adotado pelo MEC em 2002, gestão Fernando Henrique Cardoso, e deixou de ser adotado em abril deste ano, gestão Luiz Inácio Lula da Silva. E Kamel sabia disso. Nem a indicação foi culpa de FHC (se é que se pode falar em culpa), nem a desclassificação foi obra de Lula. Kamel sabia que o processo de seleção de livros, pelo MEC, virou uma política de estado, ainda na gestão FHC, e não houve nenhuma modificação que sinalizasse para sua politização (NASSIF, 2007).

Nassif continua dando mais informações sobre o processo de avaliação do livro didático que o articulista Kamel não comentou:

O livro em questão entrou para a lista em 2002, devido à avaliação positiva de um professor da UNESP (Universidade Estadual Júlio de Mesquita Neto), ainda na gestão Paulo Renato de Souza. Quem retirou de pauta, na última avaliação, em abril passado, foi a Universidade Federal do Rio Grande do Norte, pois os novos avaliadores entenderam que as ressalvas eram fortes demais para que permanecessem. Nem o MEC interferiu no primeiro movimento, nem interferiu no segundo. A única mudança que fez foi ampliar o número de universidades de quatro para oito. O livro acabou vetado por um avaliador de uma nova universidade incluída na seleção. Repito, Kamel sabia disso. Mais. Na seleção de trechos que colocou, do livro, menciona o que considera loas aos regimes comunistas. Mas deixou de fora trechos do livro em que há críticas explícitas ao marxismo, a Stalin e a Mao (NASSIF, 2007).

O confronto entre Kamel e Nassif acerca do Livro Didático produziu um debate posto representar conflitos outros que operam na política e tem na educação um mecanismo de inculcação de ideologias.

Na linha de Kamel, os articulistas Luiza Bandeira e Rodrigo Vizeu, da Folha de São Paulo, em matéria publicada em 01 de maio de 2011, reacenderam a discussão acusando o livro didático de História distribuído no âmbito do PNLD de trazer:

[...] críticas ao governo Fernando Henrique Cardoso (PSDB) e elogios à gestão de Luiz Inácio Lula da Silva (PT). Uma das exigências do MEC para aprovar os livros é que não haja doutrinação política nas obras utilizadas. O livro "História e Vida Integrada", por exemplo, enumera problemas do governo FHC (1995-2002), como crise cambial e apagão, e traz críticas às privatizações. Já o item "Tudo pela reeleição" cita denúncias de compra de votos no Congresso para a aprovação da emenda que permitiu a recondução do tucano à Presidência. $\mathrm{O}$ fim da gestão FHC aparece no tópico "Um projeto não concluído", que lista dados negativos do governo tucano. Por fim, diz que "um aspecto pode ser levantado como positivo", citando melhorias na educação e a Lei de Responsabilidade Fiscal. Já em relação ao governo Lula (2003-2010), o livro cita a "festa popular" da posse e diz que o petista "inovou 
no estilo de governar" ao criar o Conselho de Desenvolvimento Econômico e Social. O escândalo do mensalão é citado ao lado de uma série de dados positivos (BANDERIA e VIZEU, 2011).

E ampliam, argumentando que:

Ao explicar a eleição de FHC, o livro "História em Documentos" afirma que foi resultado do sucesso do Plano Real e acrescenta: "Mas decorreu também da aliança do presidente com políticos conservadores das elites". Um quadro explica o papel dos aliados do tucano na sustentação da ditadura militar. Quando o assunto é o governo Lula, a autora -que à Folha disse ter sido imparcial- inicia com a luta do PT contra a ditadura e apenas cita que o partido fez "concessões" ao fazer "alianças com partidos adversários". Em dois livros aprovados pelo MEC, só há espaço para as críticas à política de privatizações promovida por FHC, sem contrabalançar com os argumentos do governo. (BANDEIRA e VIZEU, 2011).

São essas reflexões que acionam perspectivas contraditórias sobre os conteúdos dos livros didáticos e, ao fazê-las, evidenciam a complexidade da questão.

A questão crucial nesse conturbado contexto passa a ser em que medida os livros didáticos de História selecionados e ofertados pelo MEC às escolas públicas do País atendem aos ditames legais pertinentes à área de educação? O documento balizador do processo avaliativo do PNLD, o Edital, é suficiente nesse intento? Existe alguma pertinência na crítica feita pela mídia impressa?

Não seria papel da história e do LD de História, em particular, fazer uma reflexão crítica a respeito dos fragmentos do passado? Enquanto conteúdo de uma ciência moderna, busca-se o caráter investigativo, o caráter crítico a respeito desses fragmentos. Entendemos que não existe uma ciência "neutra", ainda mais no campo das Ciências Humanas, um LD "neutro", no sentido de não ter posicionamentos políticos? E fica uma questão: seria desejável um livro didático, em particular um livro de História, que não dialogasse com o universo do educando?

Quando os acusadores do LD de História indagam se esse instrumento pedagógico faria propaganda política e ideológica de um governo, de um partido ou de uma doutrina, não estariam, em seu discurso acusatório praticando um discurso ideológico? Eles não estariam a confundir, deliberadamente ou não, doutrinação político-partidária com escolha ideológica do autor? Como Nassif (2007) acusou Kamel (2007)?

Para além do papel da ciência História e de seu conteúdo, no momento em que pleiteiam um conteúdo neutro, já se configura um discurso ideológico, relembrando Marx (1846) uma "falsa consciência", no caso, da História. Uma mistificação do que seria a história, alijada de sua realidade concreta, feita pelos homens. Buscam eles uma banalização do conteúdo do LD 
de história? Um discurso feito para camuflar as disputas históricas entre os homens ao longo dos séculos?

Em meio a tantos conflitos o que deve, pois, preconizar o conteúdo do LD de História?

Para responder a essa questão, é preciso identificar, evidenciar e problematizar o conceito de qualidade presente nos Editais do PNLD 2008, 2011 e 2014 os quais dão os rumos para implementação da política.

Como dito antes, as seguintes questões complementares poderão nos ajudar a compreender melhor o processo de análise dessa temática:

1) Como os dirigentes e profisssionais do Ministério da Educação entende o conceito de qualidade que ancora o Programa Nacional do Livro Didático?

2) Os Editais do PNLD são suficientes para garantir os preceitos estabelecidos pelo próprio PNLD?

Diante do exposto, este estudo divide-se em quatro partes além da introdução, a saber:

No Capítulo 1, “O Livro Didático em foco: Ideologia e/ou qualidade?”, traçamos um breve histórico do PNLD, bem como o escopo da estrutura da avaliação pedagógica do LD, com os principais atores do processo. Também, delimitamos as linhas gerais da avaliação, seus critérios e princípios. Abrimos um debate com autores a respeito das problemáticas que envolvem o PNLD.

Neste primeiro capítulo, delimitamos o conceito de ideologia e como o mesmo se apresenta no programa. Assim como, também, traçamos o conceito de qualidade e o de qualidade da educação. Por fim, problematizamos o discurso advindo do MEC para com o PNLD.

Já no Capítulo 2, "Resultados e análise: o Edital do PNLD em foco", delineamos as ferramentas deste estudo como o percurso teórico-metodológico utilizado. A seguir, passamos à análise dos Editais do PNLD de 2008, 2011 e 2014.

Nesse sentido, analisamos o Objetivo deste documento, seus princípios Gerais, o papel esperado do LD, a legislação vigente aplicada e os objetivos dos critérios da avaliação pedagógica. Comparamos a estrutura dos Editais no que diz respeito ao processo de avaliação pedagógica, observamos as principais diferenças entre os respectivos documentos estudados.

No Capítulo 3, "Confrontos, encontros e desencontros na Política do Livro Didático", aprofundamos a análise com relação aos objetivos, princípios e critérios que balizam a avaliação pedagógica; para isso, utilizamos o Decreto $n^{\circ} 7.084 / 2010$ como elemento que estrutura os editais utilizados neste estudo. 
Nesse capítulo são apresentados os dados dos questionários aplicados junto aos avaliadores dos PNLD de 2008, 2011 e 2014 na área de História no polo da Universidade Federal do Rio Grande do Norte/UFRN. Esta instituição coordenou o processo de avaliação de LD de História no recorte deste estudo. Aqui, podemos colher e analisar os problemas existentes no processo de avaliação pedagógica, bem como colher as sugestões para o aprimoramento do programa.

Por fim, elaboramos uma "Conclusão com recomendação: perspectivas para o PNLD." Nesta, sintetizamos e analisamos, a partir das respostas dos avaliadores, as principais recomendações para Secretaria de Educação Básica/SEB/MEC no sentido de buscar o aprimoramento dos processos relativos ao PNLD, objetivo fulcral em um Mestrado Profissional, custeado pelo MEC. 


\section{CAPÍTULO 1 - O LIVRO DIDÁTICO EM FOCO: IDEOLOGIA OU QUALIDADE?}

Ao buscar resposta à questão central deste estudo, "em que medida os livros didáticos de História selecionados e ofertados pelo MEC às escolas públicas do país atendem aos ditames legais pertinentes à área de educação?" Faz-se necessário, antes, apresentar um breve histórico do Programa Nacional do Livro Didático (PNLD), para depois prosseguirmos no entendimento de sua estrutura como, por exemplo, o papel dos Editais. Por fim, o intuito é analisar os conceitos de qualidade e de ideologia e suas conexões com PNLD e livro didático de História.

O PNLD é o mais antigo dos programas, em andamento, voltado à distribuição de obras didáticas aos estudantes da rede pública de ensino brasileira. Ao longo do século XX, essa distribuição foi sendo aperfeiçoada e teve diferentes nomes e formas de execução. A distribuição de obras didáticas pelo Estado brasileiro seguiu um percurso histórico. Para uma melhor compreensão do percurso, elaboramos o quadro a seguir:

Quadro 1 - Percurso Histórico do PNLD

\begin{tabular}{|c|c|c|}
\hline Ano & Atividade & Contexto \\
\hline 1929 & $\begin{array}{l}\text { O Estado cria um órgão específico para legislar sobre políticas } \\
\text { do livro didático, o Instituto Nacional do Livro (INL), e } \\
\text { contribui para dar maior legitimidade ao livro didático } \\
\text { nacional, consequentemente, auxilia no aumento de sua } \\
\text { produção. }\end{array}$ & $\begin{array}{l}\text { Crise da primeira } \\
\text { república conhecida como } \\
\text { "República do Café com } \\
\text { leite" (1889-1930) }\end{array}$ \\
\hline 1938 & $\begin{array}{l}\text { Por meio do Decreto-Lei } n^{\circ} 1.006 \text {, de } 30 / 12 / 38 \text {, é instituída a } \\
\text { Comissão Nacional do Livro Didático (CNLD), estabelecendo } \\
\text { sua primeira política de legislação e controle de produção e } \\
\text { circulação do livro didático no País. }\end{array}$ & $\begin{array}{l}\text { Período da Era Vargas } \\
\qquad(1930-1945)\end{array}$ \\
\hline 1945 & $\begin{array}{l}\text { Pelo Decreto-Lei } n^{\circ} 8.460 \text {, de 26/12/45, é consolidada a } \\
\text { legislação sobre as condições de produção, importação e } \\
\text { utilização do livro didático, restringindo ao professor a } \\
\text { escolha do livro a ser utilizado pelos alunos, conforme } \\
\text { definido no art. } 5^{\circ} \text {. }\end{array}$ & $\begin{array}{l}\text { Fim da Era Vargas e } \\
\text { retorno de um período } \\
\text { democrático. }\end{array}$ \\
\hline 1966 & $\begin{array}{l}\text { Um acordo entre o Ministério da Educação (MEC) e a } \\
\text { Agência Norte-Americana para o Desenvolvimento } \\
\text { Internacional (Usaid) permite a criação da Comissão do Livro } \\
\text { Técnico e Livro Didático (Colted), com o objetivo de } \\
\text { coordenar as ações referentes à produção, edição e } \\
\text { distribuição do livro didático. }\end{array}$ & $\begin{array}{c}\text { Período da Guerra Fria } \\
1945 \text {-1991/ Período do } \\
\text { Regime Militar 1964-1985 }\end{array}$ \\
\hline 1970 & $\begin{array}{l}\text { A Portaria } n^{\circ} 35 \text {, de 11/3/1970, do Ministério da Educação, } \\
\text { implementa o sistema de coedição de livros com as editoras } \\
\text { nacionais, com recursos do Instituto Nacional do Livro (INL). }\end{array}$ & $\begin{array}{c}\text { Período do Regime Militar } \\
\text { 1964-1985 }\end{array}$ \\
\hline
\end{tabular}




\begin{tabular}{|c|c|c|}
\hline 1971 & $\begin{array}{l}\text { O Instituto Nacional do Livro (INL) passa a desenvolver o } \\
\text { Programa do Livro Didático para o Ensino Fundamental } \\
\text { (Plidef), assumindo as atribuições administrativas e de } \\
\text { gerenciamento dos recursos financeiros até então a cargo da } \\
\text { Colted. A contrapartida das Unidades da Federação torna-se } \\
\text { necessária com o término do convênio MEC/Usaid, } \\
\text { efetivando-se com a implantação do sistema de contribuição } \\
\text { financeira das unidades federadas para o Fundo do Livro } \\
\text { Didático. }\end{array}$ & $\begin{array}{c}\text { Período do Regime Militar } \\
\text { 1964-1985 }\end{array}$ \\
\hline 1976 & $\begin{array}{l}\text { Pelo Decreto } n^{\circ} 77.107 \text {, de 4/2/76, o governo assume a compra } \\
\text { de boa parcela dos livros para distribuir a parte das escolas das } \\
\text { unidades federadas. Com a extinção do INL, a Fundação } \\
\text { Nacional do Material Escolar (Fename) torna-se responsável } \\
\text { pela execução do programa do livro didático. Os recursos } \\
\text { provêm do Fundo Nacional de Desenvolvimento da Educação } \\
\text { (FNDE) e das contrapartidas mínimas estabelecidas para } \\
\text { participação das Unidades da Federação. }\end{array}$ & $\begin{array}{r}\text { Período do Rę } \\
1964-1\end{array}$ \\
\hline 1983 & $\begin{array}{l}\text { Em substituição à Fename, é criada a Fundação de Assistência } \\
\text { ao Estudante (FAE), que incorpora o Plidef. Na ocasião, o } \\
\text { grupo de trabalho encarregado do exame dos problemas } \\
\text { relativos aos livros didáticos propõe a participação dos } \\
\text { professores na escolha dos livros e a ampliação do programa, } \\
\text { com a inclusão das demais séries do ensino fundamental. }\end{array}$ & $\begin{array}{c}\text { Período do Regime Militar } \\
\text { 1964-1985 }\end{array}$ \\
\hline 1985 & $\begin{array}{l}\text { Pelo Decreto-Lei no } 91.542 \text {, de } 19 \text { de agosto de } 1985 \text {, foi } \\
\text { instituída a distribuição de obras didáticas para o Programa } \\
\text { Nacional do Livro Didático (PNLD). }\end{array}$ & $\begin{array}{l}\text { Transição do Regime } \\
\text { Militar para a nova } \\
\text { República democrática } \\
\end{array}$ \\
\hline 1996 & $\begin{array}{l}\text { Ocorre a primeira avaliação de livros de História de } 5^{\mathrm{a}} \text { a } 8^{\mathrm{a}} \\
\text { série. }\end{array}$ & blica \\
\hline 1997 & $\begin{array}{l}\text { Houve a publicação do primeiro Guia do Livro, material este } \\
\text { que continha as resenhas das coleções selecionadas e } \\
\text { indicadas para que os professores escolhessem as obras } \\
\text { didáticas mais adequados ao projeto pedagógico de sua escola. }\end{array}$ & $\begin{array}{l}\text { Nova República } \\
\text { democrática }\end{array}$ \\
\hline 2010 & $\begin{array}{l}\text { Pelo Decreto-Lei n }{ }^{\circ} 7.084 \text {, de } 27 \text { de janeiro de } 2010 \text {, o Estado } \\
\text { normatiza a avaliação, compra e distribuição de livros } \\
\text { didáticos para a escolarização básica em todo o país. }\end{array}$ & $\begin{array}{l}\text { Nova República } \\
\text { democrática }\end{array}$ \\
\hline
\end{tabular}

Fonte: elaborado com os dados do Portal do Fundo Nacional de Desenvolvimento da Educação ${ }^{2}$

O percurso histórico e institucional do PNLD, elencado no Quadro I, evidencia o ano de 1997 como um marco de caráter democrático para o desenvolvimento de uma política pública de distribuição de materiais didáticos às escolas públicas do país. Naquele ano, tivemos a publicação do primeiro Guia do Livro Didático, material que continha as resenhas das coleções selecionadas e indicadas para que os professores escolhessem as obras didáticas mais

\footnotetext{
${ }^{2}$ FNDE: http://www.fnde.gov.br/programas/livro-didatico/livro-didatico-historico
} 
adequadas ao projeto pedagógico desenvolvido pela sua escola. Era o início do processo de avaliação pedagógica dos LD pelo programa.

A seguir, especificamente no ano de 1998, houve a primeira avaliação pedagógica de livros de História da $5^{\mathrm{a}}$ à $8^{\mathrm{a}}$ série, a segunda etapa do ensino fundamental. Posteriormente, por meio do Programa Nacional do Livro Didático para o Ensino Médio (PNLEM) 2004/2005, foram, gradativamente, inseridas obras para o ensino médio.

Outro passo importante para o PNLD consolidar-se como uma política educacional foi sua normatização através da publicação do Decreto $\mathrm{N}^{\mathrm{o}} 7.084$, de 27 de janeiro de 2010, que reforça e viabiliza a avaliação, compra e distribuição de livros didáticos para a escolarização básica em todo o Brasil, balizada em instrumentos legais que visam oferecer um produto de qualidade para alunos e professores das escolas públicas do país.

Atualmente, são avaliadas e distribuídas aos alunos das escolas públicas obras didáticas de Letramento e Alfabetização, Alfabetização Matemática, Língua Portuguesa, Matemática, Ciências, História, Geografia, Arte, Química, Física, Biologia, Sociologia, Filosofia, Inglês e Espanhol e dicionários de Língua Portuguesa.

No corrente ano, por meio do Edital do PNLD 2016, voltado para os anos iniciais do ensino fundamental cujo processo está em andamento, também se passou a ter opção de obras integradas de Ciências Humanas e da Natureza, do $1^{\circ}$ ao $5^{\circ}$ ano, bem como o livro regional integrado de História, Geografia e Arte, para ser usado no $4^{\circ}$ ou $5^{\circ}$ ano. Também em 2015 iniciou-se o processo do PNLD 2017 com vistas a avaliar e selecionar Livros Didáticos para a segunda fase do ensino fundamental, os anos finais. Nesse Edital, temos os componentes curriculares: I) Linguagens, com Língua Portuguesa, Língua estrangeira moderna (Inglês e Espanhol) e Arte; II) Matemática; III) Ciências da Natureza; IV) Ciências Humanas, com História e Geografia.

Além das obras referentes a essas disciplinas, são avaliadas, selecionadas e distribuídas obras complementares aos livros didáticos para apoio à aprendizagem nos anos iniciais do ensino fundamental e acervos de dicionários de Língua Portuguesa, segundo indicação do próprio Ministério da Educação. 


\section{1- Estado da arte}

Em um levantamento sobre os estudos a respeito da temática que envolve o Programa Nacional do Livro Didático, coletamos alguns trabalhos que consideramos pertinentes ao presente estudo.

A obra "O livro didático de História: políticas educacionais, pesquisas e ensino", organizada pela Profa. Dra. Margarida Dias de Oliveira e pela Profa. Dra. Maria Inês Sucupira Stammatto, traz um estudo sobre a "aproximação das formas de ação do Estado brasileiro na proposição do currículo prescrito disseminado das instituições escolares públicas estatais, a partir do processo de distribuição de livros didáticos aos professores e alunos do Ensino Fundamental." (OLIVEIRIA e STAMMATTO, 2007, p. 20).

As autoras referenciadas possuem uma vasta experiência na área de avaliação e seleção das obras didáticas de História no âmbito do PNLD, sendo a obra uma referência no debate sobre o livro didático de História, motivo pelo qual poderá trazer subsídios para os questionamentos propostos neste estudo.

Também se apresenta oportuna a obra de Batista (2001), "Recomendações para uma política pública de livros didáticos", quando aborda o marco que foi a instituição do PNLD e seus critérios de avaliação e seleção, os quais garantiriam um processo adequado na busca de ofertar um material didático com qualidade.

Mas nem toda bibliografia traz uma crítica positiva em se tratando do PNLD, a exemplo da crítica feita pelo autor e proprietário de uma empresa editorial Francisco Sampaio e a autora Aloma Carvalho, "Com a palavra, o autor: em nossa defesa, um elogio à importância e uma crítica às limitações do Programa Nacional do Livro Didático" referindo-se às limitações que o PNLD apresentaria em seu modelo de avaliação pedagógica. (SAMPAIO e CARVALHO, 2010).

Outra crítica, quanto ao modelo de avaliação pedagógica das obras inscritas no PNLD, foi feita por Brito (1997). Em “A sombra do caos”, defende que o programa apresenta caráter "autoritário" em relação ao conteúdo. Argumenta que os autores ficavam subjugados a um modelo rígido e não flexível da análise de conteúdo imposto sobre suas respectivas obras.

Para compreender melhor esses pontos de conflito e avançando na temática definida para este estudo, fizemos uma seleção de artigos que problematizam uma suposta veiculação tendenciosa e a existência de um caráter ideológico no LD de História no âmbito do PNLD. O intuito é apresentar um levantamento acerca das posições críticas em defesa de obras indicadas e em relação ao próprio programa. 
Uma pesquisa realizada na biblioteca eletrônica $\operatorname{SciELO}^{3}$ através de seus periódicos como o Cadernos CEDES ${ }^{4}$, o Cadernos de Pesquisa ${ }^{5}$ e a revista Educação e Pesquisa ${ }^{6}$, no mês de fevereiro de 2014, mostrou que com a palavra chave "Livro Didático" aparece em uma longa lista de publicações, contudo, a temática ideologia e livro didático de História nos anos finais do ensino fundamental foi mínima, o que chama a atenção diante da visibilidade da crítica à educação como ideológica nos últimos anos observada, principalmente, na mídia, em sites na internet e outros.

Pré-selecionamos apenas três artigos no Cadernos CEDES e seis artigos no Educação e Pesquisa, nenhum localizado na revista Educação e Pesquisa.

Os artigos que contribuíram para a abertura de um debate dentro do foco de pesquisa foram Ferreira e Franco (2008), "Desafios do ensino de história”, que trata da acusação do jornalista Ali Kamel a um dos livros didáticos adotados pelo governo dentro do PNLD e a obra "Nova história crítica", de Mário Schimdt. O jornalista acusa o MEC de distribuir livros didáticos com ideologia de esquerda.

Outro é o artigo de Silva (2012), “A Fetichização do Livro Didático no Brasil”, que trata das diversas polêmicas sobre a qualidade dos livros didáticos veiculadas pela imprensa nos últimos anos e da supervalorização desse instrumento didático/pedagógico em nossa cultura escolar.

Acrescentam-se os trabalhos de Munakata (2004) em "Dois manuais de história para professores"; de Terrazzan e Zambon (2013) em "Políticas de material didático no Brasil"; e de Pereira e Pereira (2009) em “Os sentidos do Golpe de 1964 nos livros didáticos de história (1970-2000)."

\footnotetext{
${ }^{3}$ O SciELO é uma biblioteca eletrônica que abrange uma coleção selecionada de periódicos científicos brasileiros. A SciELO é o resultado de um projeto de pesquisa da FAPESP - Fundação de Amparo à Pesquisa do Estado de São Paulo, em parceria com a BIREME - Centro Latino-Americano e do Caribe de Informação em Ciências da Saúde. A partir de 2002, o Projeto conta com o apoio do CNPq - Conselho Nacional de Desenvolvimento Científico e Tecnológico. O Projeto tem por objetivo o desenvolvimento de uma metodologia comum para a preparação, armazenamento, disseminação e avaliação da produção científica em formato eletrônico.

${ }^{4} \mathrm{O}$ periódico Caderno CEDES contém publicações temáticas do Centro de Estudos Educação e Sociedade, CEDES, dirigidos por profissionais e pesquisadores do campo educacional com o objetivo de abordar questões importantes e atualizadas no campo educacional. ISSN 1678-7110 online version.

${ }^{5}$ A revista Cad. Pesqui., Cadernos de Pesquisa é um periódico da Fundação Carlos Chagas, instituição considerada centro de excelência pesquisa educacional, criado em 1971, tendo como principal objetivo divulgar as pesquisas acadêmicas produzidos na área.

${ }^{6}$ Educação e Pesquisa é uma revista da Faculdade de Educação da USP, tem como missão a publicação de artigos e relatórios de pesquisa em educação, bem como resenhas de livros, documentos especiais e traduções feitas por professores e pesquisadores da USP e de outras instituições. ISSN 1517-9702.
} 
No conjunto, essas produções nos ajudam a problematizar os meandros do PNLD. Para tentar responder em que medida os livros didáticos de História selecionados e ofertados pelo MEC às escolas públicas do País atende aos ditames legais pertinentes à área de educação?

Na obra "Políticas de material didático no Brasil", os autores Terrazzan e Zambon (2013) apresentam os resultados de um estudo sobre os processos de escolha de livros didático, no âmbito do Programa Nacional do Livro Didático, na etapa do Ensino Médio. Apesar de ser outra etapa do PNLD que não será foco neste estudo, os autores nos trazem uma perspectiva interessante do trabalho na questão de "Como escolas de educação básica (EEB) organizam e desenvolvem ações para a escolha do LD". Esses autores tentam "compreender como algumas políticas educacionais - de avaliação da educação básica, de formação de professores e de materiais didáticos - incidem em escolas públicas de educação básica e que implicações trazem para o trabalho escolar, em especial para o trabalho docente desenvolvido nessas escolas" (2013, p. 586).

Em relação aos anos finais do ensino fundamental, os autores defendem a premissa de “... que as orientações e as determinações presentes nas políticas educacionais se configuram como prescrições para o desenvolvimento das atividades cotidianas das instituições escolares. "(2013, p. 586).

Nessa vertente, há um reconhecimento de que o Livro Didático de História, avaliado e selecionado no âmbito do Programa Nacional do Livro Didático e distribuído para todas as escolas públicas do País, teria, portanto, um caráter curricular no conteúdo a ser ministrado em sala de aula. Terrrazzan e Zambon (2013) colocam em pauta a importância do LD para a realidade escolar do Brasil:

1) a amplitude que os programas de material didático assumem na atualidade no Brasil, tornando o nosso País o maior comprador de livros didáticos do mundo;

2) a consolidação do PNLD como política de Estado (e não de governo), estabelecendo um mecanismo próprio de escolha dos livros pelos professores;

3) a presença de livros didáticos no cotidiano das escolas e das salas de aula do País, reafirmada a partir da consolidação do PNLD, de uma forma mais efetiva e intensa e com perspectivas de melhor utilização.

(2013, p. 587)

Esses três pontos levantados pelos autores, a amplitude do PNLD, o PNLD como política de Estado, desde antes de 2010, ainda na gestão do Ministro da Educação, Paulo Renato, no governo FHC, e a presença em sala de aula do LD, apontam para importância não só do programa em si, mas também fazem referência à política educacional instituída no país 
após a redemocratização nos anos 80, bem como, depois da implementação da nova LDB de 1996.

O artigo avança de maneira objetiva e clara a respeito da "História do PNLD", desde sua origem com o decreto $\mathrm{n}^{\mathrm{o}}$ 91.542, de 19 de agosto de 1985, passando pelos marcos da instituição de uma comissão de especialistas em 1993 encarregada de avaliar a qualidade das obras mais solicitadas pelos professores, assim como a universalização de atendimento a todas as etapas da Educação Básica em 2009. A regulamentação se deu com a Resolução CD/FNDE $\mathrm{N}^{\mathrm{o}}$ 60, de 20 de novembro de 2009, e com a publicação do Decreto $\mathrm{n}^{\mathrm{o}} 7.084$, de 27 de janeiro de 2010, que "regulamentou a avaliação e a distribuição de materiais didáticos para toda a educação básica, garantindo, assim, a regularidade da distribuição de livros.” (2013, p. 589).

Os autores abordam um ponto importante no contexto desta pesquisa: a questão da qualidade das obras selecionadas e distribuídas dentro do PNLD. Nas palavras deles "Resulta deste processo de avaliação a recomendação de um conjunto de obras para cada componente curricular, as quais atendem ao mínimo de qualidade estabelecido no edital.” (2013, p. 589).

Os autores utilizam, como fonte de informações, a "modalidade sujeito", e como instrumento para coleta de dados, a entrevista estruturada, mediante roteiro específico. $\mathrm{O}$ universo estabelecido por eles foram as 27 escolas públicas de educação básica da cidade de Santa Maria/RS que possuem o ensino médio como etapa de escolaridade. Utilizaram a técnica de categorização temática e estabeleceram categorias de análise a posteriori.

Como conclusão, Terrazzan e Zamboni (2013) afirmam que o comprometimento dos órgãos públicos com a escolha dos $\mathrm{LD}$, no âmbito da escola, é mínimo. A falta de participação das instituições educativas no processo de escolha dos livros didáticos a serem utilizados nas escolas e, por outro lado, a participação mais ativa das Editoras nesse processo, o que é proibido por resolução do Fundo Nacional de Desenvolvimento da Educação/ FNDE, foram marcantes na pesquisa, o que contraria os princípios gerais do próprio PNLD, fragilizando tanto seus objetivos como seu discurso.

Essa participação das Editoras também foi objeto de denúncia e crítica de outra autora. O artigo de Hofling (2000) "Notas para discursão quanto à implementação de programas de governo: em foco o Programa Nacional do Livro Didático" trata do Programa Nacional do Livro Didático/ PNLD no contexto das políticas públicas sociais focadas nos princípios de democratização das decisões e distribuição de benefícios sociais à população, e traz à tona a questão dos grupos editoriais inseridos no contexto do programa, bem como as implicações advindas dessa imersão. A autora problematiza a importância do PNLD: 
O PNLD é sistematicamente mencionado - e até mesmo politicamente usado - para referendar o nomeado "sucesso" da política educacional brasileira. É um programa de proporções gigantescas, envolvendo em seu planejamento e implementação questões gigantescas [...] Pela amplitude e pelo caráter que assume no âmbito da política educacional, considero o PNLD uma unidade autônoma para análise, estando nele próprio contidos os contornos de uma política pública de corte social, como é a política educacional. (HOFLING, 2000, p. 160).

Como unidade autônoma, para além de seus objetivos de política educacional, o PNLD enfrenta interesses políticos e econômicos; é alvo de propaganda de governo; pressão do mercado e palco do lobby das Editoras envolvidas no contexto do programa.

Hofling (2000) desenvolve uma análise política do PNLD e de sua descentralização, ou seja, os fatores e atores que determinam a política de compra e distribuição dos livros didáticos. Aí, o papel dos grupos editoriais envolvidos aparece mais claramente. Ela identifica que há uma estreita relação entre o Estado e os grupos editoriais privados no planejamento e na implementação do Programa, e isso, na visão dela, poderia comprometer a natureza dessa política social, impedindo um dos pontos que seria crucial - o viés democrático da política do livro didático.

Há de se questionar se a influência desses grupos editoriais se estende à confecção dos editais do PNLD. Isso seria possível em que pese todo o arcabouço legal envolvido nesta área? Esta é uma problemática que se articula ao critério de qualidade do PNLD que tentamos delinear.

Como dito, este objeto nasce também das críticas e elas emergem de muitos lados.

O artigo de Ferreira e Franco (2008) parece ser o que mais contribui para a abertura de um debate dentro do foco de estudo pretendido por nós, pois trata da acusação feita a um dos livros didáticos adotados dentro de um ciclo do PNLD, a obra didática "Nova história crítica", de Mário Shmidt.

Os autores afirmam que a partir dessa polêmica surgida no âmbito do jornalismo, abriuse uma importante e grande discussão. Para eles:

[...] sobre a formação dos alunos e a produção de material didático [...] a discussão trouxe à tona questões latentes no ensino de história. No horizonte da produção dos livros didáticos e das discussões na imprensa apareceram duas variáveis fundamentais para nossa análise: em primeiro lugar, a dimensão econômica, que envolve altas cifras e grande número de editoras ávidas por vender seus produtos, e em segundo lugar, o controle da história a ser contada nos livros. (FERREIRA e FRANCO, 2008, p. 80) 
A referida polêmica ganha ares político-ideológicos quanto ao seu conteúdo, e claro, ganha também o peso da disputa econômica entre as editoras e seu "produto", o livro didático, o lucro que esse possibilita. Essa questão também, no contexto dos jogos de poder que envolvem tal política educacional, faz emergir uma pergunta: a aprovação ou não aprovação de um LD dentro de um ciclo do PNLD estaria ligada não ao seu conteúdo, conforme apregoado na legislação balizadora do programa, mas estaria, em verdade, conectada a interesses econômicos dos envolvidos nesse contexto, como grupos editoriais e os membros das diferentes instâncias governamentais?

Os autores abordam a dinâmica do PNLD e sua importância na escola pública brasileira e o quanto de recurso financeiro está implicado. Depois, começam a destrinchar a acusação feita por parte da imprensa e a problematizar a questão da ideologização dos livros didáticos de história usando, por exemplo, uma matéria jornalística da Revista Época de setembro de 2007, destacando:

[...] a disputa pelo discurso "verdadeiro" da história assume um tom retórico na seção "Ensino tendencioso", em que trechos do livro de Schmidt são utilizados para indicar "o que falta dizer" sobre determinados temas. Segundo a matéria, o livro trataria de forma parcial assuntos como a revolução cubana, o fim do comunismo, o liberalismo, o capitalismo. Esse julgamento, do qual os historiadores profissionais foram alijados, traz à baila o grande desafio da produção de material didático: o que devemos ensinar às nossas crianças? $\mathrm{E}$ como? (FERREIRA e FRANCO, 2008, p. 80).

Diante dessa indagação, Ferreira e Franco (2008) observam a questão da formação acadêmica dos profissionais de história que, em grande parte nos anos 1980, teve um viés marxista. A partir disso, analisam o livro didático e acompanham as reinterpretações do passado feitas pelos historiadores acadêmicos. Observam se o constante diálogo entre passado e presente, inerente a qualquer reflexão histórica, estaria estendido aos livros didáticos, sob pena de termos grandes hiatos entre o que se discute na academia e o que se ensina nas escolas do país.

Os autores alertam para certo descompasso entre o que o MEC julga aceitável (delimitado nas regras estipuladas na avaliação e seleção das obras inscritas no PNLD) e os livros didáticos que os professores escolhem. Eles afirmam "embora tenha criado um padrão qualitativo para a feitura dos materiais, ainda está longe de produzir livros que atendam aos requisitos de qualidade desejáveis do ponto de vista historiográfico.” (2008, p. 81). Também alertam para a questão da linguagem do "politicamente correto" contida nas últimas avaliações do PNLD: 
[...] não resolve o que nos parece ser um grave e recorrente erro, qual seja, o de apresentar verões caricaturais sobre o passado [...] não impediu a produção de materiais irregulares do ponto de vista historiográfico. Em suma, obras "politicamente corretas" não são necessariamente "bons livros" de história. (FERREIRA e FRANCO, 2008, p, 81-82).

E o que é "politicamente correto" para eles?

Os autores chegam a uma percepção de que "O desinteresse da academia pela produção de didáticos e a incúria de grande parte dos que tradicionalmente se encarregam dessa tarefa reafirmam o quadro preocupante." (Ferreira e Franco, p. 82, 2008). Ou seja, os autores que escrevem o livro didático estariam sem acompanhar mais diretamente a produção acadêmica na área de história, e os historiadores não demonstrariam um interesse em produzir essas obras didáticas.

Assim, o conhecimento histórico não seria atualizado ou reavaliado no conteúdo dos livros didáticos. Os autores também relativizam o papel do livro didático dentro da sala de aula:

A nosso ver, os livros representam um papel significativo, porém não exclusivo, no processo de aprendizagem, estando, portanto, longe de responder sozinhos pela qualidade do ensino de história. Um ponto fundamental [...] é a formação dos professores. (FERREIRA e FRANCO, p. $86,2008)$.

Alertam para a necessidade de cuidar da formação inicial e continuada dos professores de história, diminuir o peso do conteúdo do livro didático e dar mais espaço e ferramentas para o conteúdo do próprio professor em sala de aula evidenciando aspectos, por exemplo, da história local.

Observam que, por causa do Regime Militar brasileiro (1964-1985), toda uma geração de professores e historiadores ficou marcada pelo discurso ideológico da ditatura. A partir desse contexto, houve uma separação prejudicial para esses profissionais: a separação entre ser professor e ser pesquisador na área de história, o que acarretou problemas para a produção e utilização do livro didático de história. Finalizam observando a necessidade de:

[...] uma relação dialógica entre academia e ensino, é preciso ressaltar a importância de se ver os problemas relacionados aos manuais didáticos como apenas uma parte de uma questão muito maior. Não é possível pensar o livro didático em separado de questões como as levantadas acima. Não deixa de ser significativo que os professores acadêmicos participem apenas episodicamente da feitura de manuais didáticos, e que docentes dos ensinos fundamental e médio repitam interpretações superadas para os acadêmicos. O recente debate na grande imprensa põe em foco uma questão: 
qual a importância do historiador em toda essa discussão? (Ferreira e Franco, 2008, p. 90). Grifo nosso.

Para os autores, a função primordial do ensino de história seria fornecer ao aluno subsídios para o entendimento das várias temporalidades que o conhecimento histórico envolve, e o mais preparado para esse exercício seriam historiadores. Entretanto, como grifado, o descompasso entre os profissionais do ensino superior e educação básica é um dos grandes gargalos a ser superado.

Para melhor compreendermos essa crítica, é preciso verificar o que se diz e o que não é dito a respeito do livro didático de História e sua relação com aspectos ideológicos.

\subsection{O processo de avaliação pedagógica}

O processo de avaliação é iniciado com a publicação do Edital de Convocação para inscrição no processo de avaliação e seleção de coleções didáticas para o PNLD, por meio do qual são apresentados os procedimentos necessários para a inscrição e os critérios de avaliação adotados nas diferentes etapas do processo. Após a inscrição, as obras são avaliadas do ponto de vista gráfico, físico e editorial - etapa sob a responsabilidade do FNDE em parceria com o Instituto de Pesquisa Tecnológica (IPT).

A seguir, um modelo de organograma do processo e dos atores da avaliação e seleção de livros didáticos no escopo do PNLD, conforme recorte desta pesquisa (PNLD 2008. 2011 e 2014): 


\section{Quadro 2 - Processo e estrutura do PNLD}

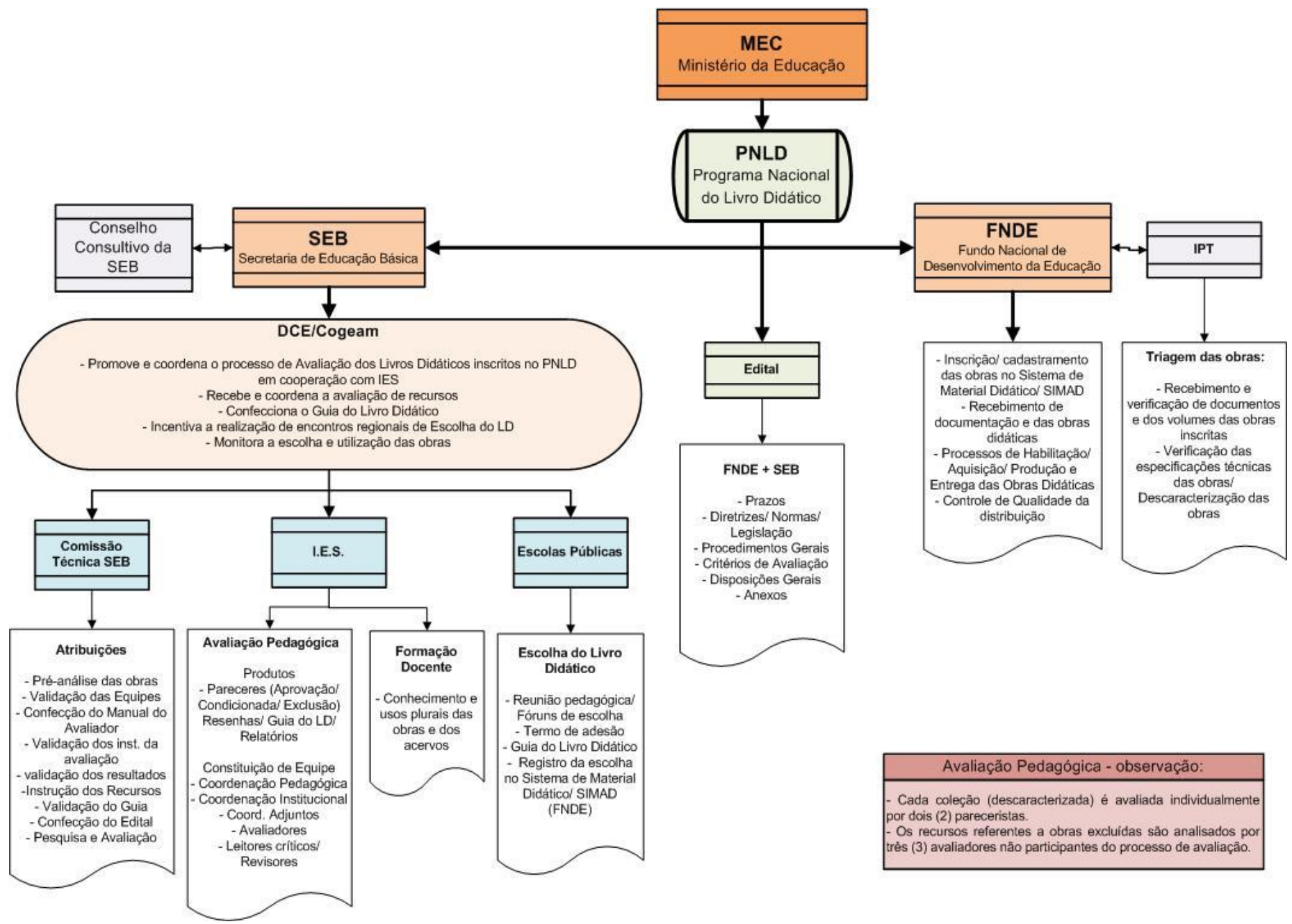

Fonte: elaborado pelo pesquisador.

O PNLD é executado pelo MEC através das ações pertinentes à SEB, a saber, composição e coordenação das equipes avaliadoras das obras inscritas, bem como a coordenação da avaliação pedagógica dos LD. Como demonstrado no quadro anterior, há no processo a participação da Comissão Técnica do $\operatorname{PNLD}^{7}$, das instituições de Ensino Superior ${ }^{8}$ e do público alvo, as escolas públicas. As ações desenvolvidas no âmbito da SEB são por sua vez acompanhadas pelas ações desenvolvidas pelo FNDE, como a coordenação da inscrição,

\footnotetext{
${ }^{7}$ No período estudado, os membros da Comissão Técnica do PNLD eram designados por portaria ministerial. A CT tinha como regra ser constituída por especialistas de cada área do conhecimento, levando-se em conta sua produção acadêmica e experiência em avaliação de materiais didáticos.

${ }^{8}$ No período estudado, a SEB/MEC convidava as instituições de Ensino Superior a participar do processo de avaliação pedagógica do PNLD. Para desenvolver esta parceria exigia-se dessas instituições notável conhecimento em avaliação de materiais didáticos, em pesquisa e estudos nas respectivas áreas do conhecimento, bem como apresentação de plano de trabalho que atendesse às exigências do MEC.
} 
compra e distribuição dos LD. Para tal trabalho, o FNDE conta com uma coordenação do livro e com os trabalhos do Instituto de Pesquisa Tecnológicas do Estado de São Paulo (IPT).

Essa estrutura institucional e técnica permite o desenvolvimento da avaliação pedagógica das obras didáticas inscritas no programa.

As obras aprovadas na primeira etapa da avaliação são enviadas para a avaliação pedagógica realizada pelas equipes pedagógicas constituídas no âmbito das universidades federais públicas brasileiras.

Ao final de cada processo do PNLD, é elaborado o Guia de Livros Didáticos, que se constitui por volumes de cada área do conhecimento, onde são apresentados os princípios, os critérios que nortearam a avaliação, as resenhas das obras aprovadas e o modelo da ficha de avaliação utilizada por cada área.

O Guia de Livros Didáticos é elaborado através dos estudos feitos pelas equipes pedagógicas e depois é enviado às escolas públicas como instrumento de apoio aos professores no momento da escolha dos livros didáticos.

O Guia do Programa Nacional do Livro Didático, PNLD 2014 de História, por exemplo, apresenta o processo de avaliação pedagógica das obras, os sujeitos envolvidos, os critérios, as etapas e as principais ferramentas empregadas pelo Programa. O Guia também oferece um perfil das obras, caracterizando a produção nacional nele representada.

Na avaliação do PNLD 2014, foi selecionado para compor o Guia de História um total de 20 obras de 26 inscritas no processo de avaliação e seleção, cada uma composta por quatro volumes, referentes ao $6^{\circ}, 7^{\circ}, 8^{\circ}$ e $9^{\circ}$ anos, além dos respectivos manuais do professor para cada ano. Segue abaixo o fluxograma do processo de avaliação e seleção de livros didáticos do PNLD 2014: 
Quadro 3 - Processo da avaliação pedagógica ${ }^{9}$

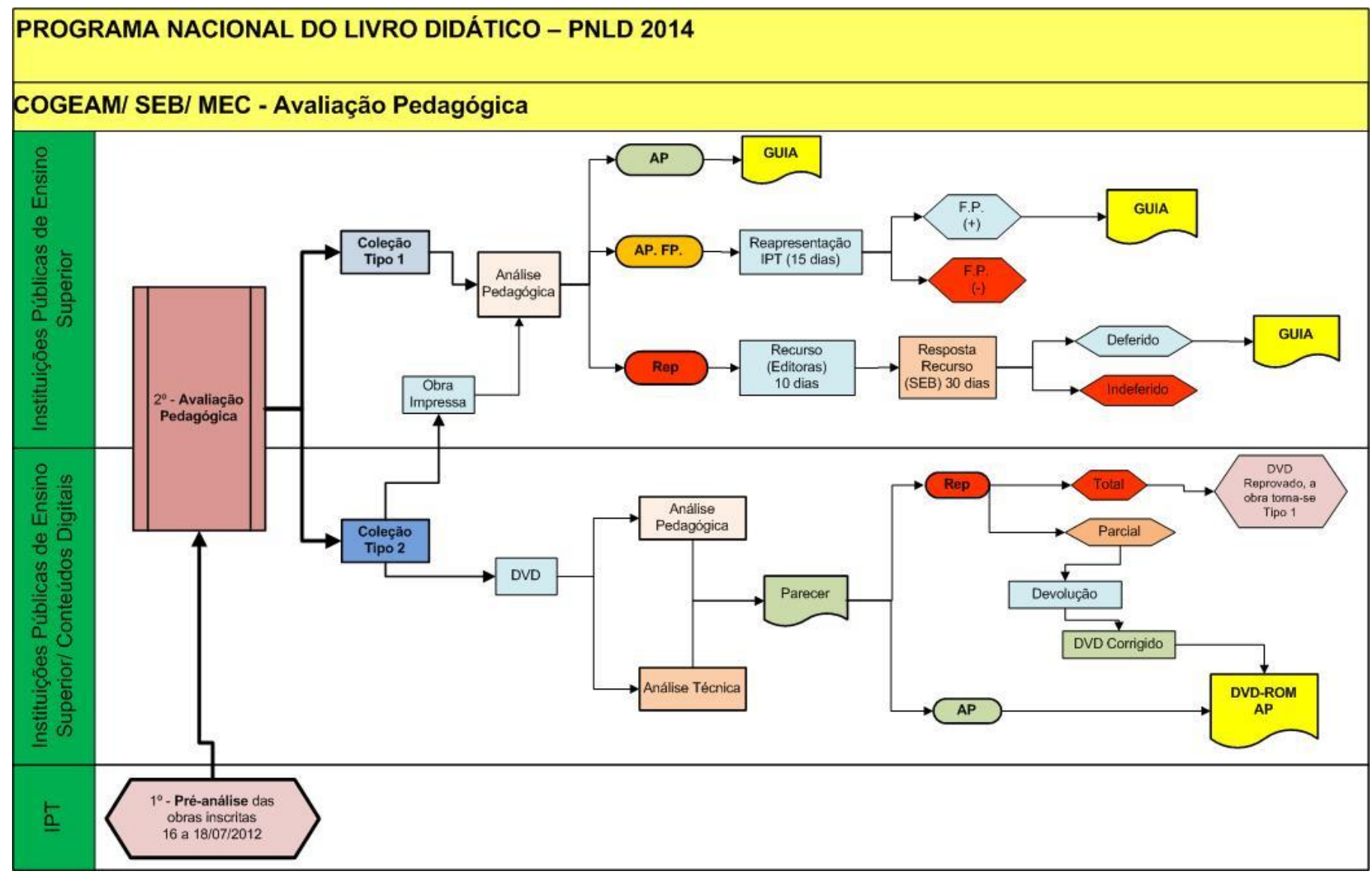

Fonte: elaborado pelo pesquisador.

Conforme demonstrado no Quadro IV, os LD inscritos no programa percorrem todo um trajeto técnico no processo de avaliação pedagógica, desde a pré-análise realizada pelo IPT, quando se verifica a qualidade material, bem como os documentos exigidos pelo edital do PNLD, passando-se à fase propriamente dita da avaliação conceitual das obras. Nessa fase, os LD inscritos conforme as categorias estipuladas em edital, tais como Coleção Tipo 1 ou Coleção Tipo 2, são submetidos à avaliação a partir de critérios estabelecidos pelo edital. No final desse percurso avaliativo, temos as obras aptas a comporem o Guia do Livro Didático do PNLD distribuído às escolas públicas com o intuito de subsidiar a escolha do livro por parte dos professores e demais profissionais da escola.

O Guia do Livro Didático do PNLD 2014 ressalta que os livros didáticos aprovados pelo Programa Nacional do Livro Didático são avaliados em relação às teorias, metodologias, conceitos e conhecimentos atuais de cada uma das áreas do conhecimento, à luz do Edital de

\footnotetext{
${ }^{9}$ No processo de avaliação pedagógica do PNLD 2014 utilizou-se o seguinte rol de siglas: AP (obra aprovada); AP.FP. (obra aprovada condicionada à correção de Falhas Pontuais); Rep (obra reprovada); F.P. + (falha pontuais sanadas); F.P. - (falha pontuais não sanadas);
} 
Convocação que rege todo o processo e das pesquisas científico-acadêmicas, de forma que as obras aprovadas sejam, na medida do possível, isentas de erros, preconceitos, inconsistências metodológicas, propagandas ou proselitismo de qualquer natureza (BRASIL, p. 13, 2013).

Os autores Ferreira e Franco (2008) têm um entendimento diferente do processo de avaliação dos LD no programa e criticam o PNLD ao afirmar que "embora tenha criado um padrão qualitativo para a feitura dos materiais, ainda está longe de produzir livros que atendam aos requisitos de qualidade desejáveis do ponto de vista historiográfico" $(2008$, p. 81). Temos então, um posicionamento crítico a respeito da atualização das obras didáticas selecionadas pelo programa e que contrapõe os seus próprios objetivos.

Os editais do PNLD, documentos balizadores do programa, estabelecem como critérios gerais de avaliação:

1- Respeito à legislação, às diretrizes e às normas oficiais relativas ao ensino fundamental.

2- Observância de princípios éticos necessários à construção da cidadania e ao convívio social republicano.

3- Coerência e adequação da abordagem teórico-metodológica assumida pela coleção, no que diz respeito à proposta didático-pedagógica explicitada e aos objetivos visados.

4- Correção e atualização de conceitos, informações e procedimentos. Grifo nosso.

5- Observância das características e finalidades específicas do Manual do Professor e adequação da coleção à linha pedagógica nele apresentada. 6- Adequação da estrutura editorial e do projeto gráfico aos objetivos didáticopedagógicos da coleção. (BRASIL, p. 13, 2013).

Pode-se observar que nesses critérios há uma preocupação do MEC em relação à legislação da área educacional, bem como a noção de construção da cidadania no processo educativo. No item 4, destaca-se a correção e atualização do conteúdo que o LD deve considerar.

Também constam dos Editais os critérios específicos de avaliação da área de História:

1- Uso do conhecimento atualizado nas áreas de História e Pedagogia.

2- Anúncio da função social da história e dos pressupostos teóricometodológicos veiculados pela coleção.

3- Estímulo ao conhecimento da historicidade das experiências sociais.

4- Desenvolvimento de conceitos, habilidades e atitudes na construção da cidadania.

5- Emprego de texto iconográfico no desenvolvimento de habilidades de leitura, interpretação, considerado sua condição de fonte para a produção do conhecimento histórico.

6- Isenção de anacronismos e voluntarismos. (BRASIL, 2013, p.13). 
Nesses critérios específicos da área de História, é pertinente ressaltar a preocupação do MEC quanto à função social da história, bem como ao conhecimento da historicidade das experiências sociais. Importante destacar, também, o cuidado com a inserção de anacronismos e voluntarismos que possuem um peso estratégico para um conhecimento crítico na área de história.

O autor Flávio Berutti (2009) atenta para o cuidado que se deve ter com as "armadilhas" que podem estar presentes em LD, os erros conceituais. $\mathrm{O}$ autor salienta que esses erros conceituais são descritos nos editais do PNLD. Do Edital do Programa Nacional do Ensino Médio 2007, antigo PNLEM, o autor destaca o que consideramos como Anacronismo:

Consiste em atribuir aos agentes históricos do passado razões ou sentimentos gerados no presente, interpretando assim a História em função de critérios inadequados, como se os atuais fossem válidos para todas as épocas. Trata-se com efeito, de distorção grave que implica explicações que comprometem totalmente a compreensão do processo histórico. (BERUTTI, 2009, p.101) Grifo nosso.

Outro "pecado capital" no contexto dos erros conceituais é o voluntarismo que:

Consiste em aplicar, a documentos e textos, uma teoria a priori, em função do que se quer demonstrar. Dessa forma, a narrativa dos fatos passados, ou presentes, é utilizada apenas para confirmar as explicações já existentes na mente do autor, que parte de convicções estabelecidas por motivos ideológicos, religiosos ou pseudocientíficos. Pode, ainda, originar-se da tentativa da aplicação de teorias explicativas, tomadas acriticamente. (BERUTTI, 2009, p.101) Grifo nosso.

Não escapa à observação do autor o conceito de nominalismo assim definido:

Quando a análise proposta abstrai-se de realidades vividas pelos sujeitos históricos, em proveito da mera descrição de quadros jurídicos, regulamentares ou institucionais. Ao invés de dar prioridade às relações sociais dos agentes históricos, que efetivamente são autores da História, atribui-se vida e vontade a instituições ou categorias de análise. (BERUTTI, 2009, p.102) Grifo nosso.

Berutti (2009) recomenda que o autor de LD deva "avaliar constantemente seu arcabouço teórico e notar que a produção acadêmica nem sempre acompanha o ritmo das transformações e das necessidades sociais" (p.102). Destaca o caráter do LD, em especial o de História, deve revelar as contradições e conflitos do saber histórico. 
Nesse sentido, o LD deve ser capaz de promover a análise, a reflexão e a interpretação dos documentos junto aos estudantes. Interessante nos parece a seguinte afirmação de Berutti (2009): "o professor deve oferecer-se como um mediador entre a opinião do autor e a cultura prévia do aluno." (p. 103). Assim, o livro didático não deve ser o único material ou "trunfo" na prática escolar em sala de aula uma vez que o professor deve chamar a si o papel de mediador do conhecimento histórico. O LD não deve ser uma fonte de "verdade" ou dogma, dado que o conteúdo histórico constitui-se como parte do fazer humano continuo, não estanque no tempo e no espaço de sua confecção. No universo da sala de aula, o LD assume diferentes interpretações.

Os critérios de avaliação mudaram ao longo dos anos de execução do Programa, buscando manter ou aperfeiçoar seu rigor. O interesse em pesquisar o tema e a relação qualidade ou ideologia, tendo como parâmetro o Livro Didático e suas conexões com o PNLD, adveio da experiência no trabalho e nos desafios do cotidiano na elaboração de editais no âmbito da Coordenação-Geral de Livros Didáticos, mas também, como dito, dos questionamentos feitos por parte da imprensa (Folha de São Paulo, Jornal o Globo), dos profissionais da educação e do público em geral a respeito de um "provável viés ideológico" que estaria contido nas obras selecionadas pelo referido programa.

Entretanto, também como historiadores de formação, sabemos do papel crítico que a disciplina História deve exercer na formação para a cidadania, e que o professor de História, como destacado por Berutti e Marques (2009), deve mediar a produção do conhecimento entre LD, aluno e fato histórico.

Nessa dinâmica, a seleção do conteúdo e as metodologias para aprendizagem são do âmbito da autonomia do Professor de História, norteado atualmente pelas Diretrizes Curriculares Nacionais da Educação Básica (DCNs). Faz-se necessário situarmos este documento e o contexto do PNLD. As DCNs, ao contrário dos Parâmetros Curriculares Nacionais (PCNs), são leis com metas e objetivos a serem buscados em cada curso, possuem caráter obrigatório. Já os PCNs não são leis.

O debate, a confecção e implementação destes documentos norteadores oficiais responderam a questão e a necessidade do debate de um currículo unificado/ nacional emanado a partir da LDB de 1996 que trouxe uma nova concepção de educação para o País.

Os PCNs foram publicados em 1998 tendo como papel de ser um referencial para a renovação e/ou reelaboração de propostas curriculares no âmbito das escolas, legitimando uma espécie currículo para o professor em sala de aula. Entre suas características trazia a ideia de temas transversais (ética, saúde, meio ambiente, orientação sexual, pluralidade cultural, 
trabalho e consumo) bem como o princípio de interdisciplinaridade das áreas do conhecimento por eixos temáticos.

As DCNs estabelecem um conjunto de princípios, critérios e procedimentos para a organização, planejamento, execução no âmbito do ensino no país. O Parecer CNE/CEB N ${ }^{\circ}$ 7/2010 justifica uma necessidade de definição de Diretrizes Curriculares Nacionais Gerais para a Educação Básica devido a emergência da atualização das políticas educacionais que consubstanciem o direito de todo o brasileiro a uma formação humana e cidadã. (BRASIL, p. 7, 2013).

Tanto a confecção de LD por parte dos autores quanto à avaliação pedagógica dos mesmos feita pelo MEC sofreram influências dos PNCs e das DCNs conforme o tempo histórico de cada edição do PNLD. Nesse sentido, parece o MEC, impor um entendimento que as DCNs sobrepõem aos PCNs na orientação da política do LD no PNLD.

No que se refere aos LD, as obras avaliadas, selecionadas e, posteriormente escolhidas pelos professores, acabam por servir de currículo a ser seguido no cotidiano da sala de aula. Nesse contexto, cabe indagar se a política de avaliação de obras didáticas do PNLD permite uma eficiente seleção de obras, capaz de fornecer um material didático que contenha os subsídios considerados adequados ao próprio professor, consequentemente à formação dos alunos em cada etapa de ensino da educação básica.

Muito antes das polêmicas jornalísticas, pesquisadores chegaram a salientar o caráter autoritário do livro didático. Brito (1997) chamou "a atenção para o caráter ideológico e autoritário do livro didático - que, além de simplificar absurdamente o conhecimento, tende a falsear a realidade e escamotear as disputas e conflitos sociais.” (p. 251). Já Sampaio (2010), autor e editor de livros didáticos, faz duras críticas e contesta a idoneidade do processo de avaliação afirmando que:

São necessárias mudanças fundamentais para impedir que a avaliação pedagógica do livro didático se consolide como um processo caro, lento, redundante, inconsistente e impregnado de erros. Não temos dúvidas de que as distorções da avaliação resultam de um sistema obscuro e sem os necessários mecanismos de controle e revisão. (SAMPAIO, 2010, p. 47).

Diante do exposto, muitas são as contradições e também as expectativas em relação ao Livro Didático. Espera-se que os LD estejam cada vez mais próximos das demandas sociais e sejam coerentes com as práticas educativas e se alinhem à autonomia dos professores. Esse instrumento deve, ainda, contribuir para que o professor organize sua prática e, ao mesmo tempo, deve fornecer sugestões de aprofundamento das concepções pedagógicas desenvolvidas 
na escola, além de ajudar o professor na busca de outras fontes e experiências para complementar o seu trabalho.

Como visto, o leque de expectativas é bem grande. Mas, para Brito (1997), haveria uma relação que "interfere intensamente no estabelecimento dos conteúdos e programas, nas práticas de ensino e na própria dinâmica do cotidiano escolar.” (p. 252). Essa relação seria o desigual peso atribuído ao conteúdo exposto no LD disponibilizado à escola e à falta de um currículo nacional mais claro para o ambiente escolar.

O edital do PNLD, na prática, assume o papel de indutor de uma política pública de ensino a ser adotada em todas as escolas públicas do país, quando determina as diretrizes que a obra deve satisfazer para ser bem-sucedida no processo de avaliação do programa. Brito (1997) bem observa essa realidade "O livro didático, que muitas vezes é a única fonte de informação e atualização do professor, impõe-se como necessidade pragmática tanto para as políticas de educação quanto para os próprios agentes pedagógicos.” (p. 253).

Diante de tamanha contradição, a primeira grande questão que se apresenta no contexto de trabalho do Programa Nacional do Livro Didático diz respeito às obras a serem avaliadas com base nos termos estabelecidos no edital, selecionadas e distribuídas, de maneira a oferecer às escolas da rede pública a "melhor obra possível."

Conforme estabelecido no Edital do PNLD 2014:

A avaliação das coleções didáticas submetidas à inscrição no PNLD 2014 busca garantir a qualidade do material a ser encaminhado à escola, incentivando a produção de materiais cada vez mais adequados às necessidades da educação pública brasileira. (BRASIL, 2013, p.53)

O edital delimita, por exemplo, quais disciplinas devem ser alicerçadas na etapa dos anos finais do ensino fundamental, que vai do $6^{\circ}$ ao $9^{\circ}$ ano, e delimita, também, quais legislações essas obras devem respeitar, além dos princípios didáticos e pedagógicos que elas devem seguir.

Dito isso, entender e problematizar a relação Qualidade e Ideologia, no âmbito do Livro Didático e suas conexões com o PNLD, é um exercício que visa contribuir para o aprimoramento das políticas educacionais do MEC.

Para tanto, precisamos explicitar o que seja, primeiramente, ideologia. 


\subsection{0 conceito de ideologia e como se apresenta no PNLD}

Voltamos à crítica que desencadeou este estudo. Nos últimos anos, a Coordenação-Geral de Materiais Didáticos recebeu inúmeras acusações feitas ao Livro Didático, tais que veiculavam conteúdos tendenciosos e que o LD de História, em particular, seria partidário de uma corrente política de esquerda, de um partido político. Nesse sentido, precisamos conceituar Ideologia, para depois problematizar se o Edital do PNLD induz que o Livro Didático de História, distribuído no âmbito do PNLD, apresenta um caráter ideológico favorável à esquerda política brasileira, no caso específico, de beneficiar o governo Lula, como explicitado no caso da obra "Nova História Crítica", de Mário Schimdt. O intuito é entendemos se há pertinência nessa acusação.

Em um sentido amplo, a palavra ideologia pode ser entendida como um conjunto de ideias, concepções ou opiniões sobre algum ponto passível de discussão.

Já enquanto teoria, ideologia assumiria um sentido sistemático interpretativo de eventos e conhecimentos a respeito do agir e da ação do indivíduo e do coletivo.

Em um sentido mais restrito, a palavra ideologia ganha contornos de conceito. Na visão de Marx e dos marxistas, ideologia assumiria um sentido negativo na medida em que passa a significar um instrumento de dominação, ou seja, uma forma de mascarar conflitos.

O sentido negativo para Marx a respeito do papel da ideologia na sociedade capitalista advém da interpretação marxiana de que nele o trabalhador estaria subjugado nas relações de poder entre classes pela exploração de seu trabalho, adjunta à alienação das etapas de produção. A argamassa nessa concepção seria a ideologia da classe dominante, que impediria a tomada de consciência por parte do trabalhador e que, em última instância, garantiria a ordem social vigente.

Avançando no entendimento do conceito de ideologia, baseado em Marx, para a filósofa Marilena Chaui (1980) seria:

Um conjunto lógico, sistemático e coerente de representações (ideias e valores) e de normas ou regras (de conduta) que indicam e prescrevem aos membros da sociedade o que devem pensar e como devem pensar, o que devem valorizar e como devem valorizar, o que devem sentir e como devem sentir, o que devem fazer e como devem fazer. Ela é, portanto, um corpo explicativo (representações) e prático (normas, regras, preceitos) de caráter prescritivo, normativo, regulador, cuja função é dar aos membros de uma sociedade dividida em classes uma explicação racional para as diferenças sociais, políticas e culturais, sem jamais atribuir tais diferenças à divisão da sociedade em classes, a partir das divisões na esfera de produção. (CHAUI, 1980, p.43). 
Para Chaui, a ideologia apresenta a função de "apagar as diferenças, como de classes e de fornecer aos membros da sociedade o sentimento da identidade social, encontrando certos referenciais identificadores de todos e para todos, como, por exemplo, a Humanidade, a Liberdade, a Igualdade, a Nação, ou o Estado”. (Chaui, p. 43, 1980).

Para Karl Marx (1846), o conceito de ideologia remete à ilusão, à falsa consciência, ou a uma concepção idealista em que a realidade é invertida e as ideias aparecem como o motor da vida real e não seu contrário. Ideologia são representações criadas pelos homens que, por sua vez, dominam o próprio homem:

Os homens, até hoje, sempre tiveram falsas noções sobre si mesmos, sobre o que são ou deveriam ser. Suas relações foram organizadas a partir de representações que faziam de Deus, do homem normal, etc. O produto de seu cérebro acabou por dominá-los inteiramente. Os criadores se prostraram diante de suas próprias criações. (MARX e ENGELS, 2007, p. 35)

Para se escapar do domínio dessa ideologia, é necessário partir de pressupostos não arbitrários e nem dogmáticos; é preciso construir uma concepção de homem, de vida e de história a partir dos "indivíduos reais, sua ação e suas condições materiais de vida, tanto aquelas que eles já encontraram elaboradas quanto aquelas que são o resultado de sua própria ação.” (Marx, p. 44).

Nesse sentido, faz-se necessário:

Ao contrário do que se sucede na filosofia alemã, que desce do céu para terra, aqui se ascende da terra ao céu. Ou, dito de outro modo, não se parte daquilo que os homens dizem, imaginam ou representam, nem do que são nas palavras, no pensamento, imaginação e representação dos outros para, a partir daí, chegar aos homens de carne e osso; parte-se, sim, dos homens em sua atividade real, e, a partir de seu processo na vida real, expõe-se também o desenvolvimento dos reflexos ideológicos e dos ecos desse processo vital. E mesmo as formulações nebulosas do cérebro dos homens são sublimações necessárias do seu processo de vida material que pode constatar empiricamente e que se encontram sobre bases materiais. Desse modo, a moral, a religião, a metafísica e qualquer outra ideologia, assim como as formas de consciência que a ela correspondem, perdem toda aparência de autonomia [...] não é a consciência que determina a vida, mas a vida é que determina a consciência. (MARX e ENGELS, 2007, p. 51-52)

Um contraponto a essa percepção do conceito de ideologia na visão de Marx pode ser muito importante na presente discussão objeto desta pesquisa: o contraponto feito a partir de Antonio Gramsci, quando salienta que a ideologia seria uma concepção de mundo definidora e 
constituidora do real (Brandão e Dias, 2007). Estes autores compreendem que o posicionamento de Gramsci a respeito da Ideologia no contexto social segue um viés diferente do apregoado por Marx, no sentido de a ideologia não ser um "mero epifenômeno do econômico, nem falsa consciência, nem sistema de ideias." (Brandão e Dias, p. 82, 2007), mas sim "uma concepção de mundo que se manifesta na ação e a organiza" (2007). Reafirmando o entendimento dado por Gramsci, ideologia como uma visão de mundo construída a partir e no corpo social e histórico, não necessariamente uma máscara ou falseador do real.

Com essas premissas iniciais, poderíamos conjecturar a partir do pensamento de Gramsci, se real for a presença ideológica nos LD de História, qual visão de mundo estariam esses a propagar?

Brandão e Dias (2007) expandem suas análises a partir do ponto de vista gramsciano sobre o papel da ideologia:

Trata-se [...] de uma escolha política que acaba por demonstrar qual é o nível de críticas (ou submissão) que se tem em relação a outras visões de mundo e qual o nível de consciência prática e a coerência orgânica que determinado bloco social tem de si mesmo. O potencial de subordinação ou de resistência ao projeto dominante é resultante deste nível de consciência que se tem em relação a si mesmo e ao projeto que se quer implementar. (BRANDÃO e DIAS, 2007, p. 85)

Partindo dessa construção, pergunta-se: Estaria o LD de História e o processo avaliativo do PNLD inseridos em diferentes lógicas e visões de mundo conflitantes? Nesse caso, o conteúdo do LD de História estaria a serviço de alguma lógica específica?

A noção de Hegemonia e sua determinação na Ideologia forjando o estabelecimento de uma visão de mundo, atribuída a Gramsci, representa uma realidade histórico-social, longe de ser uma farsa. Nessa construção, dar-se-iam três condições básicas: i) a capacidade de uma classe fundamental (subalterna ou dominante) de elaborar uma visão de mundo própria, ii) a realização de uma reforma intelectual e moral que estabeleça o campo ideal para a primeira se considerar e, finalmente, iii) a capacidade de essa classe disputar e impor politicamente a sua visão de mundo perante o escopo social. Um movimento político e contraditório em que as relações de forças reais na sociedade evidenciam conflitos de toda natureza, inclusive ideológico.

Gramsci ajuda a entender a questão do Estado e de Ideologia. Segundo Brandão e Dias (2007), para Gramsci o Estado está articulado organicamente com a sociedade. Não seria como 
alguns atualmente veem, ou querem, uma nítida separação entre Estado e sociedade civil; ao contrário, para o pensador italiano:

[...] a distinção entre sociedade civil e Estado é de natureza metodológica e não orgânica, o que o faz pensar o estado como ligado à sociedade, vinculado ao conjunto das vontades coletivas que se articulam e organizam, expressando contraditoriamente as relações e as subjetividades nele presentes. (BRANDÃO e DIAS, 2007, p. 91)

O Estado incorporaria as demandas da sociedade civil e a sociedade política. Dessa forma, a política educacional estaria ou deveria estar consonante com esse contexto múltiplo e contraditório. E, para fazer juz à história, o PNLD deveria fazer respeitar a diversidade de conceitos, expressando, mesmo que contraditoriamente, o movimento do corpo social.

Nesse sentido, a política pública em educação, no escopo do PNLD, deveria também ter o papel de "conceber o mundo do grupo social fundamental (hegemônico ou dominante) sobre a totalidade dos grupos subordinados"? (BRANDÃO e DIAS, 2007). Estariam os princípios contidos na legislação aplicada e no próprio Edital do PNLD a cumprir seu papel de revelar diferentes visões de mundo do Estado e da sociedade brasileira? O arcabouço legal utilizado no processo do PNLD, visando à formação de crianças e adolescentes para a cidadania, estaria a expressar tal movimento? Não seria essa visão de cidadania que permeia os editais e que visa garantir a qualidade do material, visto por alguns como ideológico posto contradizer determinada forma de encarar o mundo, o cerne da questão?

Em suas considerações finais, Brandão e Dias (2007) observam que "as vontades coletivas articuladas e organizadas nos vários momentos e conjunturas e em torno de interesses diversos se manifestam nos discursos ideológicos" de forma diversificada. A ideologia teria uma existência real, material, posto orquestrar atitudes e práticas, por vezes, de dominação. Os autores falam em ideologia como visão de mundo, como racionalidade de classe. A partir disso, baseando-se nas acusações feitas ao Livro Didático, buscar ver se o LD de História está a representar alguma visão de mundo, hegemônica ou contra hegemônica, ajuda a entender o que vem a ser qualidade no PNLD?

Avançando mais, este material didático estaria, quando apregoa a formação cidadã do educando, voltado para a emancipação do indivíduo enquanto membro da classe trabalhadora (um retorno provocativo a Marx) ou a serviço da classe dominante? O que o Estado, imbuído nesse contexto de visões de mundo, estaria a endossar? Esse movimento, se houver, é premeditado? Pode ser percebido nos Editais do PNLD? 
O PNLD é balizado por leis tais como a LDB de 1996, como também pelos princípios da Constituição da República Federativa do Brasil de 1988 em cujo preâmbulo está indicado o compromisso de:

[...] instituir um Estado Democrático, destinado a assegurar o exercício dos direitos sociais e individuais, a liberdade, a segurança, o bem-estar, o desenvolvimento, a igualdade e a justiça como valores supremos de uma sociedade fraterna, pluralista e sem preconceitos, fundada na harmonia social e comprometida, na ordem interna e internacional, com a solução pacífica das controvérsias... (BRASIL, 1988)

$\mathrm{Na}$ base do corpo regulatório da nação, evidencia-se o compromisso com um Estado Democrático, com uma sociedade pluralista e sem preconceitos. Diante disso, conceitos norteadores do PNLD podem ser interpretados como a "visão de mundo" estabelecida nos meandros da política pública em educação desenvolvida pelo Estado, em particular no PNLD?

Para ir além do conceito de Ideologia a partir de Marx, buscamos a leitura de ideologia do filosofo francês Louis Althusser partindo do texto "Subjetividade, ideologia e educação", do autor Sílvio Gallo (1998). Quando esse autor trabalha conceitos caros a Althusser como aparelhos ideológicos e constituição do sujeito, indica que o objetivo de Althusser seria o de construir uma teoria da ideologia em geral, o que faltaria em Marx (1998).

Fala-se em aparelhos ideológicos do Estado, e a escola seria um deles. Essa instituição funcionaria através do convencimento para solidificar o reconhecimento necessário de um indivíduo e não de um sujeito. O primeiro carregaria a alcunha de um ser na massa; o segundo, de um ser reconhecido. Estaria a escola e, principalmente a ferramenta didática, o LD, a cumprir algum desses papéis? Forjar um ser na massa ou formar um sujeito na sociedade, com valores e compromissos cidadãos?

Baseado em Althusser, Gallo (1998) bem observa estes conceitos:

[...] tudo acontece simultaneamente: a ideologia "interpela" o indivíduo, e no seu "reconhecimento ideológico" ele se faz sujeito, tornando-se apto para a prática cotidiana dos rituais que encarnam aquela ideologia. "A existência da ideologia e a interpelação dos indivíduos enquanto sujeitos é uma única e mesma coisa", diz ele. (GALLO, p. 140, 1998)

O Sujeito só poderia existir em um contexto social, uma noção de exterioridade. Isso faria com que vivesse a ideologia como algo natural e não como algo artificial, seria o existir do sujeito algo paradoxal (Gallo, 1998). No entender do autor, a partir do pensamento de 
Althusser sobre ideologia e seus aparatos de manutenção e dominação, estaria o sujeito preso neste paradoxo:

[...] a princípio, sujeito é aquele que se reconhece e é reconhecido, é o construtor de suas próprias ações, é livre, em outras palavras; mas, por outro lado, sabemos que o sujeito só se descobre sujeito dentro de um dado referencial ideológico, e que suas ações na verdade não são livres, mas estão inscritas em um código de ação definido por aquele referencial ideológico. O ato de tornar-se sujeito é pois um ato de "libertação" e um ato de "sujeição" ao mesmo tempo. (GALLO, p. 140, 1998)

A ideologia, nesse sentido, seria elemento constituidor do sujeito, seria um fenômeno social. Nesse caminho, Althusser realiza uma descrição fenomenológica do conceito de ideologia, diferente do que faz o materialismo histórico-dialético: Ideologia como uma subjetivação, ou seja, um produto da subjetividade. Gallo (1998) observa que Althusser aponta diversas instituições sociais que funcionam como aparelhos ideológicos do Estado, estes encarregados de veicular a ideologia.

Com base na crítica feita ao LD por atores de fora do processo de avaliação pedagógica do PNLD que o veem como portador de um discurso ideológico, no sentido de ser um discurso que não procura entender o sentido da História e do conteúdo do LD de História em particular, e mais, quando definimos o discurso não ideológico como sendo aquele que evidencia conflitos e contradições históricas, não estaria os LD selecionados pelo PNLD alinhados ao fim último do ensino de História que seria de formar cidadãos críticos e comprometidos com a realidade social?

Esses mesmos atores alheios ao processo de avaliação pedagógica do PNLD não estariam eles a fazer propaganda ideológica do discurso que consideram como válido? Os críticos, Kamel (2007), por exemplo, não estariam, de forma sutil e por isso perigosa, defendendo que o conteúdo do LD deva ser neutro, ignorando o processo histórico e social da coexistência entre grupos humanos? Suas diferenças e semelhanças, encontros e desencontros?

A questão é: a quem interessa essa "naturalização" das contradições sociais? Das desigualdades sociais? Um LD "neutro" como querem alguns, seria a chave para os críticos do PNLD? Estamos em um contexto onde "visões de mundo" enfrentam-se, e uma delas quer se sobrepor a outra mesmo que, para isso, o princípio constitucional do pluralismo seja cerceado? Parece que é isso que está em jogo nessa arena de acusações.

O MEC, para a avaliação e seleção de obras didáticas a serem distribuídas às escolas públicas do país, fundamenta-se na Lei de Diretrizes e Bases da Educação Nacional nº 9.394/96 
ao tratar dos princípios e fins da Educação Nacional. A LDB (9.394/96) estabelece no seu Artigo $3^{\circ}$ :

O ensino será ministrado com base nos seguintes princípios:

I - igualdade de condições para o acesso e permanência na escola;

II - liberdade de aprender, ensinar, pesquisar e divulgar a cultura, o pensamento, a arte e o saber;

III - pluralismo de ideias e de concepções pedagógicas;

IV - respeito à liberdade e apreço à tolerância; [...]

IX- garantia de padrão de qualidade;

$\mathrm{X}$ - valorização da experiência extra-escolar;

XI - vinculação entre a educação escolar, o trabalho e as práticas sociais."

(BRASIL, 1996, Art. 3º inc. III,)

Esse dispositivo legal em que se apoia o PNLD no âmbito do MEC garante, em seu artigo $3^{\circ}$, inciso III, "o pluralismo de ideias e de concepções pedagógicas”, o que significa que não haveria exclusão a priori de uma obra que se posicionasse a respeito de uma ideologia política, reafirmando o princípio do pluralismo preconizado pela Lei. O problema é se apenas uma dada visão se sobrepuser às demais.

Nesse sentido, a própria legislação orienta que as obras contenham posicionamento crítico e diverso a respeito de um dado fato ou contexto histórico. Ou, ao menos, essa legislação serviria de mote a ser alcançado dentro do processo de avaliação de LD no PNLD. A questão emblemática é a confusão gerada entre "posicionamento crítico" e propaganda ideológica de cunho político-partidário de esquerda como acusam certos setores afetos ao PNLD. Diante desse imbróglio, outros emergem.

No mesmo artigo $3^{\circ}$ da LDB, um complicador é inserido na discussão: o conceito de "padrão de qualidade". O direcionamento para certa qualidade está presente tanto na LDB, quanto nos Editais e nos Guias dos Livros Didáticos do PNLD. A ideia de qualidade seria a garantia da criticidade tão cara ao ensino de História? E isentaria o PNLD de ter alguma relação com possível ideologia contida em livro didático de História?

Um princípio adotado pelo MEC para nortear a avaliação e seleção de obras didáticas inscritas no âmbito do PNLD está assim disposto no Edital do PNLD 2011:

É preciso que o livro didático contribua com o trabalho do professor no sentido de propiciar aos alunos oportunidades de desenvolver ativamente as habilidades envolvidas no processo de ensino e aprendizagem, e, além disso, buscar a formação dos alunos como cidadãos, de modo que possam 
estabelecer julgamentos, tomar decisões e atuar criticamente frente às questões que a sociedade, a ciência, a tecnologia, a cultura e a economia têm colocado ao presente e, certamente, colocarão ao futuro. (BRASIL, 2011, p. 2011) (grifo nosso)

Nesse dispositivo legal, pode-se dizer que opera uma contradição quando estipula como princípio que o LD deve contribuir para o desenvolvimento de uma postura crítica do educando? Não, se considerarmos que essa é a função do ensino de história. A materialização dessa orientação em Livro Didático, para alguns, estaria, ao mesmo tempo, por dolo ou negligência, permitindo a propagação de uma ideologia em benefício de um posicionamento "político" e partidário?

A questão que fica: até que ponto o Edital de avaliação e seleção de obras didáticas e os demais documentos balizadores desse processo garantiriam uma obra "isenta" de conteúdo político ideológico como querem alguns? Ou seria mais sensato pensar nesse mesmo Edital como um documento norteador de uma "qualidade" possível e desejada para as obras inscritas no processo do PNLD?

A partir desses questionamentos, faz-se necessário definirmos o que se entende por "qualidade" da obra didática já que esse conceito está estipulado nos Editais e demais documentos pertinentes ao universo do PNLD, e parece estar intrinsecamente relacionada à acusação de ideologia que atinge os LD de História. O que se refere aos alicerces do ensino de história, referente à autonomia do cidadão e ao direito às configurações políticas partidárias do país parece estar sendo confundido com ideologia de esquerda, acrescido do juízo de valor dos denunciantes.

Para responder a essa segunda questão, é preciso entender o conceito de qualidade tão apregoado nos referidos documentos oficiais do MEC, ter uma noção do que se entende por ideologia, bem como averiguar se há mesmo articulação entre as duas.

\section{$1.4 O$ conceito de qualidade da educação}

A educação evoca diversos enfoques: ora é considerada a ferramenta principal para a emancipação do indivíduo em uma sociedade competitiva, ora é considerada meio de formar o indivíduo com vista a ter um papel ou utilidade no mercado. Também é interpretada por alguns como um produto, ou seja, uma mercadoria a ser consumida, e outros de âmbito mais filosófico.

Neste estudo, nos referimos à educação formal ensinada na instituição escolar. Por muitas vezes, atribui-se à educação o adjetivo qualidade, ou seja, qualidade da educação. 
Assim como o conceito educação pode ser tratado por diversos matizes, o mesmo acontece com o conceito de qualidade associado ao de educação. Ambos os conceitos, educação e qualidade, dependem da construção histórica de seu tempo e do uso que os indivíduos fazem deles.

Consideramos pertinente responder à seguinte indagação: o que é qualidade, e qualidade da educação, especificamente no universo do PNLD?

Depois de responder a essa indagação, alertamos para outra em particular, visto o propósito de contribuir com critérios para o Edital do PNLD.

Na contemporaneidade ocidental, vivemos ainda sob a égide de um sistema econômico chamado capitalismo (Nunes, 1997) envolto em um universo tecnológico. Esse contexto perpassa a vida do indivíduo ${ }^{10}$, no ambiente privado e público.

Segundo esse mesmo autor, o Brasil, como "filho" recente dessa "ocidentalidade" 11 ", durante todo o século XX, trilhou caminhos que visavam um lugar ao sol no rol das nações tidas como modelo a ser alcançado. A partir dos anos 1990, indivíduos foram alocados em posições de poder e influência no Estado segundo os ditames do neoliberalismo ${ }^{12}$ em voga nas nações desenvolvidas do Ocidente. Na seara da educação, uma nova visão foi colocada em prática, consequentemente, estruturou-se, ou pelo menos se tentou estruturar, uma nova concepção para o locus principal da educação mantida pelo Estado - a escola pública. Ato contínuo, elevou-se para a condição de mote principal o conceito de qualidade da educação. Mas o que se entende por qualidade da educação?

Segundo Pedro Demo (1994), o conceito de qualidade da educação perpassa por um "sentido humano", ou seja, "dentro de valores e fins historicamente considerados desejáveis e necessários, eticamente sustentáveis", tendo como objetivo "o desafio de fazer história humana com o objetivo de humanizar a realidade e a convivência social.” (Demo, p. 12, 1994). Conforme o autor, perpassa nesse corolário a qualidade política, o humanismo e a formação para a cidadania.

\footnotetext{
10 Temos ciência que desde a década de 1960, vertentes contrarias ao materialismo histórico estão em curso, inclusive no campo da História como disciplina. Exemplo dos pós-marxismo, pós-estruturalismo, pósmodernidade, pós- socialismo, entre outros. Não obstante, não nos filiamos a estas correntes e buscamos aqui evidenciar ainda o aspecto estruturante que o PNLD pode exercer na Educação dado seu caráter de abrangência e infiltração, e por seu alinhamento com a política de formação do Estado brasileiro.

${ }^{11}$ Ocidentalidade diz respeito à civilização ocidental que segundo Nunes (1997) corresponde a uma parte muito pequena do globo, aquela constituída pelas nações do noroeste da Europa e dos Estados Unidos.

${ }^{12}$ Para Gentili (2004) Neoliberalismo é um complexo processo de construção hegemônica da classe dominante em duas vertentes: a primeira como um conjunto de reformas concretas no plano econômico, político, jurídico e educacional, a segunda como uma ideologia que valide estas reformas como as únicas aplicáveis na conjuntura contemporânea do Estado e da sociedade.
} 
A partir desse arcabouço interpretativo, que não é único, podemos comparar essa visão de qualidade da educação mais progressista ${ }^{13}$ com outro matiz ideológico que é chamado de “qualidade mercantil da educação" por Pablo Gentili (2007), que o contextualiza da seguinte maneira:

[...] na América Latina o discurso da qualidade referente ao campo educacional começou a desenvolver-se em fins da década de 80 como contraface do discurso da democratização [...] esta operação foi possível - em parte - devido ao fato de os discursos hegemônicos sobre a qualidade terem assumido o conteúdo que este conceito possui no campo produtivo, imprimindo aos debates e às propostas políticas do setor um claro sentido mercantil de consequências dualizadoras e antidemocráticas. No campo educativo, o discurso da qualidade foi assumindo a fisionomia de uma nova retórica conservadora funcional e coerente com o feroz ataque que hoje sofrem os espaços públicos... entre eles, a escola das maiorias. (GENTILI, 2007, p. 115).

Para essa linha "mercantil”, a qualidade seria um conteúdo voltado para as necessidades do mercado, balizadas nas ideologias do neoliberalismo e nos conceitos e linguagens do universo das empresas privadas. Seria, segundo essa linha, o ethos privado balizando o locus público, visando a uma melhora geral dos procedimentos e do resultado o desempenho escolar. Lembrando-se de alguns princípios dessa vertente, a competitividade entre os indivíduos.

A transposição ideológica do neoliberalismo empresarial para a educação se dá em sua transformação em mercadoria, produto. E, como tal, somente aqueles que podem pagar para adquirir tal produto serão capazes de ter uma "educação de qualidade." Nessa perspectiva, a escola e seu "produto" estão imbuídos de alguns adjetivos valorizados pelo mercado, tais como a noção de eficiência, competitividade e êxito. Pablo Gentili (2007) trata a questão como "vocabulário" de uma nova retórica conservadora, dadas suas conexões com os ideários do neoliberalismo, e que será assim caracterizada:

A esta altura dos acontecimentos, ninguém duvida que temos de educar "para a cultura do trabalho"; o que, em bom português quer dizer "educar para a cultura do mercado". Os termos "eficiência", "produtividade", "produto educativo", "rentabilidade", "custos da educação", "competição efetiva", "excelência", "soberania do consumidor", "cliente-aluno", etc. não são um produto alucinado de nossa exagerada crítica ao mundo dos negócios. Tratase simplesmente do vocabulário que compartilham aqueles que professam sua fé nesta nova retórica. (GENTILI, 2007, p. 158)

\footnotetext{
${ }^{13}$ Qualidade socialmente referenciada. Análises de políticas públicas como encontradas em Dourado, Libâneo, Saviani e Curry.
} 
O que esse discurso neoconservador do conceito de "qualidade da educação" não observa é que uma educação de cunho mercantil, fundamentada nos valores mencionados anteriormente, alicerça um privilégio: o de se poder comprar o produto, educação. Esse privilégio, por sua vez, alicerça uma clássica divisão social entre os incluídos e os excluídos, alimentando a exploração do homem pelo homem, raiz que sustenta o modo de produção capitalista.

Gentili (2007) bem observa uma transposição do discurso em volta da educação. Nos anos 80, tínhamos a bandeira do discurso democrático. Já nos anos 90, passamos a ter a bandeira do discurso de qualidade formada, como se destacou, pelo discurso empresarial. O autor acertadamente salienta a necessidade de se buscar um novo sentido do conceito de qualidade na educação, diferente, é claro, do discurso neoconservador voltado para as necessidades e lógica do mercado.

Diante desse contexto, podemos fazer algumas articulações entre o conceito de qualidade da educação e a qualidade esperada no livro didático de história. Este livro deve sinalizar um conteúdo balizado em uma qualidade tida como progressista, no sentido de valorização do sujeito no exercício da cidadania, conforme os princípios estabelecidos pela constituição de 1988.

Mas por onde caminharia esse novo conceito de qualidade da educação? Gentili (2007) sinaliza:

[...] trata-se de destruir e combater esta nova retórica que se expande de forma bastante envolvente, com a força implacável do senso comum dominante [...] trata-se de construir um novo sentido que leve a qualidade da educação ao status de direito inalienável que corresponde à cidadania, sem nenhum tipo e restrição ou segmentação de caráter mercantil. (GENTILI, 2007, p.172)

Sobre esse "senso comum", Teodoro (2011) observa que:

[...] nas últimas duas décadas do século 20, assistiu-se à afirmação de um novo senso comum no discurso e nas políticas públicas de educação, assente numa redução dos conceitos de democracia às práticas de consumo, de cidadania a um individualismo possessivo e de igualdade ao ressentimento e medo do outro. (TEODORO, 2011, p. 312).

Esse "novo" conceito de qualidade da educação, considerando o sentido democrático e progressista seria, conforme Gentili (2007) preconiza, o novo caminho rumo ao combate do "senso comum" explicitado por Teodoro (2011), que condiciona a educação a um produto voltado para as necessidades educativas do mercado. Por exemplo, formar uma mão de obra qualificada, mas qualificada não num sentido crítico e sim em um sentido operativo do sistema 
de produção em voga, operacionalizar suas tecnologias, mas não as usar de forma crítica, a serviço das necessidades do próprio cidadão e não do sistema.

Pablo Gentili (2007) vai além. Quando trabalha o sentido de qualidade balizada em uma "democratização radical do direito à educação", observa que é preciso transformar "a qualidade em um direito e não em uma mercadoria vendida ao que der a melhor oferta. A escola pública é o espaço onde se exercita esse direito, não o mercado." (Gentili, p. 176, 2007). Ou, pelo menos, deveria ser. Neste contexto, o livro didático deveria corroborar para uma educação democrática e progressista, apresentar um conteúdo crítico.

Podemos visualizar o livro didático inserido neste formato? Como um direito. Uma obra didática que preconize esses valores?

Partindo do pressuposto de qualidade da educação não como mercadoria, voltada para o mercado e balizada por seus valores, mas vista como direito que deve ser para todos e com o objetivo de emancipação do indivíduo, há de se considerar que, em uma sociedade capitalista que alimenta a exploração do homem pelo homem, materializar essa proposição não é tarefa fácil. São muitas as contradições em meio as quais o LD é pensado e elaborado, aspectos próprios do universo conflituoso das políticas públicas envolvidas em disputas desde a formulação (do PNLD), passando pela implementação, culminando no monitoramento e avaliação no caso da materialização do PNLD.

Nesse sentido, retomamos a proposta inicial de verificar se o discurso da "qualidade da educação" embasa o PNLD e como esse se apresenta na aprovação do Livro Didático: (i) como uma ferramenta para a qualidade, a serviço de uma educação emancipatória do indivíduo, ou o seu contrário, (ii) como um material tendencioso que objetiva apresentar um conteúdo partidário ideológico de esquerda a serviço do governo, conforme os críticos do programa, ou, ainda, (iii) se o PNLD sucumbe ao discurso neoconservador e, na prática, serve aos interesses educativos do mercado, sendo arrolado em meio a disputas editoriais que não necessariamente estão comprometidas com uma educação de qualidade. Um ponto a ser como dito, considerado em relação a esses itens no campo das políticas públicas, é que eles não são excludentes, pelo contrário, são concomitantes e convivem de forma tensa e conflituosa. 


\subsection{O discurso do MEC}

No discurso oficial do MEC, a avaliação, seleção, aquisição e distribuição desse material diz garantir a "qualidade" segundo os preceitos legais pertinentes ${ }^{14}$.

Entretanto, antecede a essa leitura uma tentativa de controle a ser explicitada. Assim, o conceito de ideologia é de grande importância, posto nos permitir observar para além da aparência e tentar compreender as disputas em que os Livros Didáticos são engendrados. O conceito gramsciano de ideologia, no sentido de "visões de mundo", nos ajuda a compreender se no LD de História está garantido o princípio constitucional de pluralismo exposto na LDB de 1996.

Relembramos que, quando observamos os discursos acusatórios a respeito do conteúdo do Livro Didático de História mencionados no início deste capítulo, indagamos se não haveria uma tentativa de controle de conteúdo por parte de alguns sujeitos da sociedade, movidos por seus próprios interesses e sobre o seu próprio entendimento do que seja "qualidade da educação".

No decorrer das reflexões sobre ideologia e qualidade, vimos que, para tratar da qualidade do Livro Didático e para além de "escolher" um lado na polêmica do conteúdo (se dos acusadores, do MEC, ou mesmo dos avaliadores), é importante atentar ao que se delineia nos Editais como qualidade, até mesmo mais que chegar aos livros didáticos, posto que esses são resultado de outros inúmeros filtros, gerando diferentes conteúdos.

Entretanto, antes mesmo de pensar conteúdos e as disputas que envolvem a escolha dos LD baseados, como o dissemos, em visões de mundo e convicções com viés ideológico, a depender do caso, se destaca e não podemos nos descurar, o próprio mercado editorial, apontado como um dos vilões a compor essa complexa teia de relações de poder que envolvem o PNLD, e se materializa nos Livros Didáticos. Conforme Schmidt e Cainelli (2004) apontam:

De modo geral, todos os livros didáticos necessitam ser compreendidos por seu processo de produção, distribuição e consumo. Esses três aspectos envolvem, historicamente, os contextos em que foram produzidos os livros políticas editoriais, como as leis oficiais que regem a forma de produção dos livros, mercado e preços, além de outros - processos de compra e venda dos livros, políticas governamentais de aquisição de livros destinados à escola e consumo, ou seja, as maneiras como os livros chegam às mãos da população brasileira, bem como suas formas de utilização. Tais aspectos sugerem que

\footnotetext{
${ }^{14}$ Essas pressões reais que incidem sobre a SEB e exigem sua constante defesa argumentativa e defensiva sobre os tramites legais estabelecidos para materializar a "qualidade da educação" aciona outro conceito, o de neutralidade, que merece ser problematizado, todavia, pela sua dimensão esse não será objeto de explanação neste momento.
} 
nenhum livro didático pode ser apreendido como produto abstrato ou neutro, distanciado do contexto histórico em que existiu ou que existe.

(SCHMIDT e CAINELLI, 2004, p. 135). (grifo nosso)

Ou seja, mergulhar na "queda de braço" que subjaz à escolha de um livro didático, com um imenso mercado para consumi-lo, já traria muitas reflexões, considerando seus impactos para consolidar ou não essa ou aquela forma de compreender as regras e condutas da nação, e isso já escancara inúmeras outras possibilidades reflexivas. Por hora, o intuito é apenas evidenciar alguns termos que se alinham às tendências discursivas: se alinhadas à emancipação e/ou voltadas para eficiência do mercado, ou se estrategicamente ambas são usadas.

Assim, constata-se que são inúmeros os caminhos, mas de todos, nesta dissertação, pelo seu objetivo próprio característico de um mestrado profissional, tentaremos traçar apenas os percursos e percalços diretamente associados ao PNLD, avaliando aspectos dos Editais 2008, 2011 e 2014 e "ouvindo" os avaliadores, não sobre os livros didáticos, mas sobre o alcance dos Editais do PNLD para apoiar a materialização da qualidade das obras de acordo com as orientações.

Em face do exposto, passemos ao primeiro objetivo: evidenciar, mesmo que de forma não muito aprofundada, mas sim problematizadora, como esses discursos de "qualidade da educação" se apresentam no PNLD e norteiam a escolha do Livro Didático na rede de ensino público no Brasil.

Que tipo de qualidade da educação o Estado brasileiro, através do PNLD, pretende para escola, a escola pública em particular? O Livro Didático pode ser um referencial nesse sentido? Pode ele ser uma ferramenta adequada para esse intento?

Há uma noção de qualidade norteada no princípio da democratização e universalização não só do acesso, mas também como característica da formação do indivíduo, emancipado. Emancipação no sentido definido por Marx (1989), ou seja, uma emancipação libertária do indivíduo, uma emancipação humana. Aquela em que o homem deixaria de submeter-se às amarras de dominação do homem pelo homem, assim definida:

A emancipação humana só será plena quando o homem real e individual tiver em si o cidadão abstracto; quando como homem individual, na sua vida empírica, no trabalho e nas suas relações individuais, se tiver tornado um ser genérico; e quando tiver reconhecido e organizado as suas próprias forças (forces propres) como forças sociais, de maneira a nunca mais separar de si esta força social como força política. (MARX, 1989, p. 30). 
Esta passagem marxiana é eminentemente crítica e libertária, posto que intrinsecamente articulada a uma consciência revolucionária, questionadora e transformadora da realidade.

Contrapor uma formação crítica do cidadão perante uma formação voltada para o mundo do trabalho apenas, ainda mais no sentido de trabalho no mundo capitalista, a dita formação para o mercado, distancia-nos da educação e seu corolário em um sentido libertário do indivíduo. Faz vigorar o seu oposto, um cabresto que cerca e molda o indivíduo a ter um papel não crítico na sociedade, mas apenas funcional.

Em termos marxistas, essa seria a crítica ao discurso pelo discurso. O indivíduo, o homem, o cidadão constituinte da sociedade, em seu caráter político, visto não como peça de trabalho humano abstrato para atender ao mercado, o capital. E, nesse sentido, falar em qualidade da educação implica o discurso, uma qualidade formativa para todos e, para além do discurso, a práxis, não a ação concreta para uns e defendida por poucos. Gentili (2007) identifica no discurso dos neoconservadores e na nova retórica da qualidade, objetivos escusos.

Precisamos aprofundar se o Livro Didático, o de História em particular, no âmbito do PNLD, pode ser uma ferramenta apta a fazer parte desse intento. Acredita-se que o LD possa ser uma ferramenta importante para o trabalho do professor em sala de aula e para a mudança de mentalidade, desde que seja fomentador da construção de um senso crítico por parte de seus interlocutores. Que o mesmo seja problematizador do saber histórico, seja ele qual for.

Todavia, isso não é tarefa fácil de averiguar, considerando-se os jogos de poder que o envolvem e, como vimos, o PNLD evoca. A questão é ficar atento também ao papel da História e do Livro Didático de História em particular, fazer uma reflexão crítica a respeito de quais fragmentos do passado devem nele estar contidos.

Há uma regra básica pertinente à área de História enquanto conteúdo de uma ciência moderna em que deve prevalecer o caráter investigativo, o caráter crítico a respeito desses fragmentos.

Quando se acusa o Livro Didático de ser tendencioso para essa ou aquela corrente, indaga-se que o mesmo faria propaganda política e ideológica de um governo, de um partido, de uma doutrina. Esses mesmos que acusam teriam submetido seu discurso acusatório a uma análise sobre as visões de mundo e convicções que sustentam seu conceito de "qualidade"? Não estariam alinhados ao que Gentili (2007) chama de retórica neoconservadora, a um discurso ideológico, um discurso neoconservador?

Em resumo, nos parece que, para além do papel da História e do LD de História e de seu conteúdo, o discurso ideológico do acusado, relembrando Marx (1846), não seria uma "falsa 
consciência" da História? Não buscam eles mesmos uma naturalização do conteúdo do Livro Didático de História a partir do seu ponto de vista?

Não é tarefa fácil. Parece-nos que esse é o ponto fulcral que envolve o PNLD e, mais que adentrar nesses jogos de poder, o intuito em um Mestrado Profissional, como dito, é propor ferramentas para a melhoria da política, no nosso caso o PNLD, especificamente o Edital do PNLD, documento primordial da avaliação pedagógica do LD. E é nesse intuito que vamos, por ora, nos ater. Assim, o próximo capítulo traz as notas sobre o percurso teórico. 


\section{CAPÍTULO 2 - RESULTADOS E ANÁLISE: O EDITAL DO PNLD EM FOCO}

Neste momento, faz-se necessário delimitar as ferramentas deste estudo no sentido de identificar e problematizar o conceito de qualidade presente nos Editais do PNLD 2008, 2011 e 2014, assim como responder às questões complementares propostas:

1) Como o Ministério da Educação entende o conceito de qualidade que ancora o Programa Nacional do Livro Didático?

2) Os Editais do PNLD são suficientes para garantir os preceitos estabelecidos pelo próprio PNLD?

Os procedimentos de pesquisa basearam-se em levantamento documental pertinente ao tema, consulta aos Guias do Livro Didático PNLD 2008, PNLD 2011 e PNLD 2014, assim como na análise do documento primordial do PNLD, os editais de convocação de 2008, 2011 e 2014. Esses editais nortearam o processo da inscrição, da avaliação e seleção de obras didáticas a serem incluídas no Guia de Livros Didáticos, Anos Finais do Ensino Fundamental. Também foram consultadas as legislações expressas nos editais, a saber, a Lei de Diretrizes e Base da Educação (LDB), Lei n ${ }^{\circ}$ 9.394, de 20 de dezembro de 1996; a Resolução CNE/CEB No 7, de 14 de dezembro de 2010 que fixa as Diretrizes Curriculares Nacionais para o Ensino Fundamental de 9 (nove) anos e o Decreto $\mathrm{n}^{\mathrm{o}}$ 7.084, de 27 de janeiro de 2010, o chamado decreto do livro didático.

O trabalho realizado ateve-se pelos motivos já expostos e que contornam o campo da implementação e avaliação do PNLD: pesquisar a relação do "discurso oficial" do PNLD contido nos princípios e critérios avaliativos de seus Editais e suas implicações práticas, bem como, a partir do que se diz nos Editais do Programa, checar, por meio de questionário aberto aplicado junto à equipe de avaliação pedagógica do PNLD de História no Ensino Fundamental, a opinião desse grupo sobre o PNLD.

Para tanto, consideramos a crítica feita sobre a possível ideologia existente no Livro Didático como ponto de partida, mas, não, necessariamente, de chegada. Consideraremos, enfim, a documentação oficial que rege o processo do PNLD, nosso objeto nesta pesquisa.

\subsection{Percurso teórico-metodológico}

Optamos por utilizar a pesquisa qualitativa, pois, como observa Augusto Triviños (2009) ao referir-se à potencialidade da pesquisa qualitativa relativamente aos limites da 
pesquisa quantitativa, "muitas informações [...] não podem ser quantificadas e precisavam ser interpretadas de forma muito mais ampla que circunscrita ao simples dado objetivo" (p. 120).

Para podermos seguir com nossos objetivos de identificar, evidenciar e problematizar as questões inerentes ao processo do PNLD, temos que ir além do estipulado nos documentos balizadores do programa. Precisamos, como identificado pelo referido autor, descobrir os fatos pelos quais se manifestam os significados dos aspectos do meio e os significados embutidos no ordenamento da legislação que norteia o programa.

Como técnica, utilizamos a análise de conteúdo. Os instrumentos legais trabalhados foram, como previsto anteriormente, as leis, decretos, pareceres, resoluções e publicações oficiais no âmbito do PNLD.

Como método, utilizamos uma abordagem de cunho dialético, pois, também como observa Triviños (2009), esse é "capaz de assinalar as causas e as consequências dos problemas, suas contradições, suas relações, suas qualidades [...] e realizar, através da ação, um processo de transformação da realidade que interessa" (p. 125). Ao aplicar essa metodologia, considerase "o contexto do fenômeno social que se estuda, privilegia a prática e o propósito transformador do conhecimento que se adquire da realidade que se procura desvendar em seus aspectos essenciais e acidentais" (p. 125).

Nesse sentido, buscamos um método com inspiração de cunho marxista, conforme nos explica Paulo Netto (2011):

[...] para Marx, o método não é um conjunto de regras formais que se "aplicam" a um objeto que foi recortado para uma investigação determinada nem, menos ainda, um conjunto de regras que o sujeito que pesquisa escolhe, conforme a sua vontade, para "enquadrar" o seu objeto de investigação. (NETTO, p. 52, 2011)

Observamos, ao avançarmos nesta pesquisa, novas determinações, novas exigências que o objeto interpõe a nós, pesquisadores. Só assim, conforme esclarece Netto (2011), poderíamos pensar nas categorias utilizadas por Marx, a saber: totalidade, contradição e mediação. Cabe ressaltar, como inspiração para a pesquisa.

Nosso interesse maior foi a preocupação com o processo, considerando o ciclo de uma política pública ficamos na formulação, mais necessariamente nos resultados e no produto. Compreender o significado e a preocupação essencial ao utilizarmos a abordagem qualitativa. Nesse sentido, torna-se apropriada a sequência delimita por Triviños (2009):

(i) - a escolha de um assunto ou problema;

(ii) - uma coleta e análise de informações; 
(iii) - o estar preparado para mudar as expectativas frente ao estudo;

(iv) - uma fundamentação teórica geral não engessada.

No andamento desta pesquisa, a utilização do método de análise de conteúdo se justificou, pois, ainda como estabelece Triviños (2009), esse método é adequado para:

[...] o desvendar das ideologias que podem existir nos dispositivos legais, princípios, diretrizes etc., que, a simples vista, não se apresentam com a devida clareza. Por outro lado, o método de análise de conteúdo, em alguns casos, pode servir de auxiliar para instrumento de pesquisa de maior profundidade $\mathrm{e}$ complexidade, como o é, por exemplo, o método dialético. Neste caso, a análise de conteúdo forma parte de uma visão mais ampla e funde-se nas características do enfoque dialético. (p. 160)

Esse arcabouço mostrou-se interessante ao se trabalhar a linguagem escrita, no caso deste estudo, os documentos norteadores do PNLD. Também foi pertinente para se realizar a classificação, a codificação e a categorização dos conceitos no objeto de estudo. Ainda, seguindo as etapas básicas da análise de conteúdo discriminadas por Triviños (2009) temos a:

(i) - pré-análise ou organização do material;

(ii) - descrição analítica através da codificação, classificação e categorização, no intuito de avançar na busca de sínteses coincidentes e divergentes de ideia;

(iii) - interpretação referencial, que seja a reflexão, a intuição.

A reflexão e intuição delimitadas no item iii, interpretação referencial, será embasada "nos materiais empíricos" que "estabelecem relações [...] com a realidade educacional e social ampla, aprofundando as conexões das ideias, chegando, se é possível, a propostas básicas de transformações nos limites das estruturas específicas e gerais.” (Triviños, 2009, p. 162).

Esse autor lança uma crítica aos investigadores/ pesquisadores que atentam somente ao que está aparente nos conteúdos dos documentos e pertencem à linha positivista. Para ele, a tendência de cunho materialista dialética de análise de conteúdo se direciona na ênfase do "estudo da ideologia e suas vinculações com variáveis complexas da vida social, como os modos e relações de produção e as classes sociais e suas formações histórica em determinadas sociedades." (Triviños, 2009, p. 162). Nesse sentido, é importante explicitarmos o alerta do autor de que a análise do contexto histórico das expressões e conceitos deve compor o estudo.

Nesse contexto, temos três expressões acerca da "qualidade" dos livros didáticos no âmbito do PNLD: i) uma que acusa haver certo caráter "tendencioso ou ideológico partidário" 
de apoio a um governo, contido nesses materiais; ii) outra, em que o "discurso oficial" do órgão encarregado da avaliação, seleção, aquisição e distribuição do material diz garantir a "qualidade" segundo os preceitos legais pertinentes; iii) e um terceiro de pessoas externas que julgam os processos sob o seu ponto de vista, sabe-se lá até que ponto também ideológico.

Retomando a linha de raciocínio de Triviños (2009), temos a observar que existe uma distância entre o que se manifesta e o que realmente se atinge na realidade dos dispositivos legais. Ou seja, precisamos ter cuidado com esse fenômeno, que é identificado como formalismo, no caso, o formalismo do dispositivo legal.

Até que ponto os Editais do PNLD estariam isentos desse caráter de formalismo em seus dispositivos legais? Ou se evidenciaria, na prática, um conjunto de formalismo nos princípios norteadores do PNLD, que parecem ou tendem a nublar visões e convicções de seus formuladores?

No decorrer desta pesquisa foi aplicado o procedimento de questionário aberto (Triviños, 2009), no sentido de elaborar algumas perguntas mais precisas e expressas em uma linguagem natural ao contexto do ambiente de pesquisa, na tentativa de apontar para os assuntos medulares do problema (p.171).

Também, para esta meta, recorremos a Netto (2011) na tentativa de sabermos nos posicionar frente ao objeto, no caso, o questionário aberto:

Para Marx [...] o papel do sujeito é essencialmente ativo: precisamente para apreender não a aparência ou a forma dada ao objeto, mas a sua essência, a sua estrutura e a sua dinâmica (mais exatamente: para apreendê-lo como um processo), o sujeito deve ser capaz de mobilizar um máximo de conhecimentos, criticá-los, revisá-los e deve ser dotado de criatividade e imaginação. (NETTO, p. 25, 2011)

Do arcabouço argumentativo de Triviños (2009) juntamente com Netto (2011), buscamos inspiração para construir uma metodologia para analisarmos e decifrarmos os meandros do processo avaliativo pedagógico no PNLD, a partir dos Editais de 2008, 2011 e 2014.

Feita a revisão que tratou de nossas escolhas teórico-metodológicas, segue um quadro síntese para elucidar os diferentes percursos trilhados: 
Quadro 4 - Percurso da pesquisa

\begin{tabular}{|c|c|c|}
\hline Questões norteadoras & Objetivos específicos & Ações \\
\hline $\begin{array}{l}\text { 1) Como o MEC entende o } \\
\text { conceito de qualidade que } \\
\text { ancora o Programa Nacional do } \\
\text { Livro Didático? }\end{array}$ & $\begin{array}{l}\text { Conceituar qualidade e } \\
\text { qualidade da educação. }\end{array}$ & $\begin{array}{l}\text { Revisão Bibliográfica. } \\
\text { Marx (1846), Chaui } \\
\text { (2004), Brandão e Dias } \\
\text { 2007), Demo (1994) e } \\
\text { Gentili (2007). }\end{array}$ \\
\hline $\begin{array}{l}\text { 2) Os Editais do PNLD são } \\
\text { suficientes para garantir os } \\
\text { preceitos estabelecidos pelo } \\
\text { PNLD? }\end{array}$ & $\begin{array}{l}\text { Analisar documentação a } \\
\text { respeito do PNLD. Verificar a } \\
\text { aplicabilidade dos Editais no } \\
\text { processo de avaliação e seleção } \\
\text { das obras do PNLD. }\end{array}$ & $\begin{array}{l}\text { Análise documental. } \\
\text { Decreto 7.084/2010, } \\
\text { Editais do PNLD 2008, } \\
2011 \text { e } 2014 .\end{array}$ \\
\hline $\begin{array}{l}\text { 3) Como os avaliadores } \\
\text { entendem o conceito de } \\
\text { qualidade que ancora o PNLD? }\end{array}$ & $\begin{array}{l}\text { Conceituar qualidade da } \\
\text { educação. }\end{array}$ & $\begin{array}{l}\text { Questionário aberto } \\
\text { amostra de } 13 \\
\text { avaliadores do PNLD } \\
(2008,2011 \text { e } 2014) \text {. }\end{array}$ \\
\hline $\begin{array}{l}\text { 4) Qual é o perfil do avaliador } \\
\text { de LD e dos autores de LD } \\
\text { inscritos no PNLD? }\end{array}$ & $\begin{array}{l}\text { Realizar o levantamento dos } \\
\text { perfis dos avaliadores de LD e } \\
\text { dos autores de LD participantes } \\
\text { do PNLD. }\end{array}$ & Análise documental. \\
\hline $\begin{array}{l}\text { 5) De que forma o } \\
\text { aprimoramento dos Editais do } \\
\text { PNLD podem contribuir para a } \\
\text { melhoria do programa? }\end{array}$ & $\begin{array}{l}\text { Sugerir a elaboração e a } \\
\text { implementação de novos e } \\
\text { aperfeiçoados critérios para os } \\
\text { Editais do PNLD. }\end{array}$ & $\begin{array}{c}\text { Elaboração de critérios } \\
\text { para o Edital do PNLD, } \\
\text { produtos técnicos desta } \\
\text { dissertação. }\end{array}$ \\
\hline
\end{tabular}

Fonte: elaborado pelo pesquisador.

A fim de visualizarmos o que preconizamos conceitualmente como qualidade da educação a partir de Gentili (2007), nos documentos balizadores do PNLD, passamos à análise das principais categorias ${ }^{15}$ contidas nestes documentos, os editais de 2008, 2011 e 2014.

\footnotetext{
${ }^{15}$ Chamamos de categorias de estudo certos itens ou critérios como os de exclusão, qualificação e princípios usados na avaliação pedagógica expostos nos Editais dos PNLD em análise. O recorte foi feito a partir do foco desta pesquisa, o trabalho com os conceitos de qualidade e de ideologia no contexto do PNLD de História nos anos de 2008, 2011 e 2014.
} 


\subsection{Análises dos Editais do PNLD 2008, 2011 e 2014.}

Algumas categorias foram abstraídas da leitura dos documentos citados, tendo em vista que os Editais do PNLD apresentam uma lista muito grande de itens e critérios que vão além de nosso foco neste trabalho. Existem critérios de ordem técnica e financeira que não dizem respeito diretamente à avaliação pedagógica em si. Critérios esses utilizados pelos processos pertinentes ao FNDE e não à SEB, que coordena a avaliação pedagógica dos LD inscritos no programa. Por isso, priorizamos as análises: do objeto, princípios gerais, papel do Livro Didático, legislação vigente, objetivo advindo da legislação, objetivo dos critérios de avaliação, critérios comuns da Avaliação Pedagógica, critérios de exclusão, critérios de qualificação, princípios específicos da área de História, critérios específicos da área de História, critérios de qualificação específicos de História.

\section{Do Objeto:}

\begin{tabular}{|c|c|c|}
\hline Edital 2008 & Edital 2011 & Edital 2014 \\
\hline $\begin{array}{l}\text { Este Edital tem por objeto a } \\
\text { convocação de titulares de } \\
\text { direito autoral para } \\
\text { inscrição no processo de } \\
\text { avaliação e seleção de } \\
\text { coleçóes didáticas das áreas } \\
\text { de Língua Portuguesa, } \\
\text { Matemática, Geografia, } \\
\text { História e Ciências } \\
\text { adequadas aos alunos dos } \\
\text { anos finais do ensino } \\
\text { fundamental, observadas as } \\
\text { condições e as } \\
\text { especificações nele } \\
\text { constantes e em seus anexos. }\end{array}$ & $\begin{array}{l}\text { Este Edital tem por objeto a } \\
\text { convocação de titulares de } \\
\text { direito autoral para inscrição } \\
\text { no processo de avaliação e } \\
\text { seleção de coleções didáticas } \\
\text { destinadas aos alunos do 6º ao } \\
9^{\mathbf{0}} \text { ano do ensino fundamental } \\
\text { - matriculados nas escolas das } \\
\text { redes federal, estaduais, do } \\
\text { Distrito Federal e municipais, } \\
\text { bem como nas escolas de } \\
\text { educação especial públicas, } \\
\text { comunitárias e filantrópicas, } \\
\text { constantes no Censo Escolar, } \\
\text { que prestem atendimento aos } \\
\text { alunos com necessidades } \\
\text { especiais. }\end{array}$ & $\begin{array}{l}\text { Este edital tem por objeto a } \\
\text { convocação de editores para o } \\
\text { processo de inscrição e } \\
\text { avaliação de coleções didáticas } \\
\text { destinadas aos alunos e } \\
\text { professores dos anos finais do } \\
\text { ensino fundamental das escolas } \\
\text { públicas que integram as redes de } \\
\text { ensino estaduais, municipais e do } \\
\text { Distrito Federal e que sejam } \\
\text { participantes do PNLD, conforme } \\
\text { condições e especificações } \\
\text { constantes deste edital e seus } \\
\text { anexos; }\end{array}$ \\
\hline
\end{tabular}

Grifo nosso.

O objeto dos editais do PNLD 2008, 2011 e 2014 é suprir o ensino fundamental em seus anos finais de obras consideradas adequadas ao ensino na rede pública. Os detentores dos direitos autorais devem adequar suas obras aos requisitos avaliativos estipulados no Edital do PNLD. Os anos abarcados para essa etapa do programa vão do $6^{\circ}$ ao $9^{\circ}$ ano. Além de observar o que preconizam os ditames legais referentes à educação brasileira, os LD participantes desses processos avaliativos precisam estar adequados às respectivas especificidades disciplinares. 


\section{Princípios Gerais:}

\begin{tabular}{|c|c|c|}
\hline Edital 2008 & Edital 2011 & Edital 2014 \\
\hline 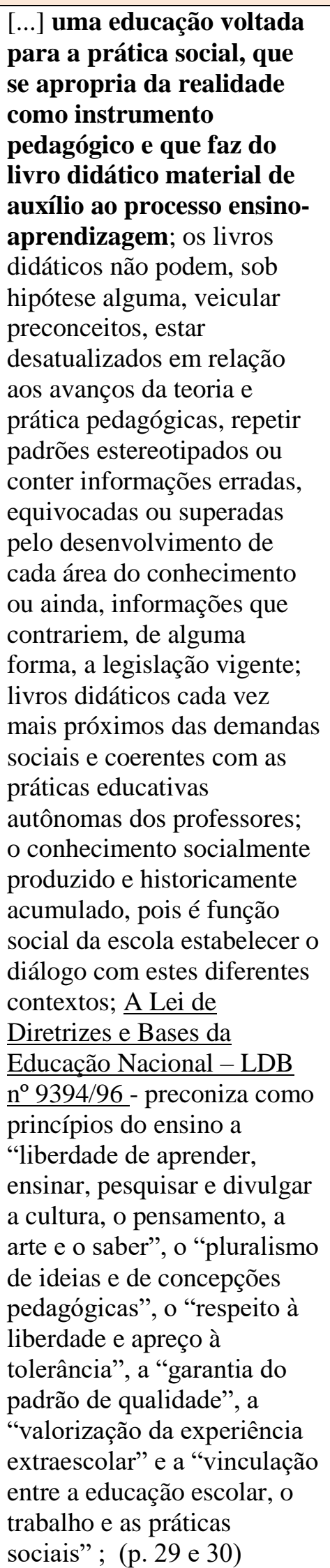 & $\begin{array}{l}\text { O acesso aos bens culturais } \\
\text { produzidos pela humanidade é um } \\
\text { dos direitos fundamentais do } \\
\text { cidadão; Organizar-se de acordo } \\
\text { com a legislação em vigor; } \\
\text { respeitar o princípio de } \\
\text { liberdade e os ideais de } \\
\text { solidariedade humana; preparo } \\
\text { para o exercício da cidadania; } \\
\text { CRF 1988: liberdade de aprender } \\
\text { e ensinar; pluralismo de ideias e } \\
\text { de concepções pedagógicas; } \\
\text { garantia de um padrão de } \\
\text { qualidade; LDB 1996: respeito à } \\
\text { liberdade e apreço à tolerância, } \\
\text { valorização da experiência } \\
\text { extraescolar e vinculação entre a } \\
\text { educação escolar, o trabalho e as } \\
\text { práticas sociais; Art. } 32 \text { LDB } \\
\text { 1996: objetivo a formação básica } \\
\text { do cidadão (capacidade de } \\
\text { aprender; compreensão do } \\
\text { ambiente natural e social, do } \\
\text { sistema político; aquisição de } \\
\text { conhecimentos e habilidades; } \\
\text { tolerância recíproca em que se } \\
\text { assenta a vida social); }\end{array}$ & $\begin{array}{l}\text { [...] educação escolar, como } \\
\text { instrumento de formação } \\
\text { integral dos alunos; o } \\
\text { princípio de liberdade e os } \\
\text { ideais de solidariedade } \\
\text { humana; preparo para o } \\
\text { exercício da cidadania e à sua } \\
\text { qualificação para o trabalho; } \\
\text { CRF 1988: liberdade de } \\
\text { aprender e ensinar; pluralismo } \\
\text { de ideias e de concepções } \\
\text { pedagógicas; garantia de um } \\
\text { padrão de qualidade; LDB } 1996 \text { : } \\
\text { respeito à liberdade e apreço à } \\
\text { tolerância, valorização da } \\
\text { experiência extraescolar e } \\
\text { vinculação entre a educação } \\
\text { escolar, o trabalho e as práticas } \\
\text { sociais; Art. } 32 \text { LDB } 1996: \\
\text { objetivo a formação básica do } \\
\text { cidadão (capacidade de } \\
\text { aprender; compreensão do } \\
\text { ambiente natural e social, do } \\
\text { sistema político; aquisição de } \\
\text { conhecimentos e habilidades; } \\
\text { tolerância recíproca em que se } \\
\text { assenta a vida social); }\end{array}$ \\
\hline
\end{tabular}

Grifo nosso. 
Quando comparamos o texto relativo aos Princípios Gerais entre os Editais do PNLD 2008, 2011 e 2014, observamos o intuito comum entre eles de seguir os princípios estabelecidos pela Lei de Diretrizes e Bases da Educação Nacional (LDB nº 9.394/96).

O edital do PNLD fundamenta-se nos princípios da LDB, a saber: capacidade de aprender; compreensão do ambiente natural e social, do sistema político; aquisição de conhecimentos e habilidades; tolerância recíproca em que se assenta a vida social. O objetivo, nesse sentido, seria uma educação que preparasse o educando em sua formação básica como cidadão. Tanto a LDB de 1996 como a CF de 1988 preconizam, em matéria de educação, a formação do cidadão, suas habilidades em exercer a cidadania, promovendo, assim, os valores de igualdade e justiça social.

Esses princípios gerais balizam o que a política de educação do Estado preconiza como qualidade que o material deve ter. Dessa forma, o LD não pode conter informações erradas e, como dito anteriormente, deve considerar uma educação que prepare o educando em sua formação básica como cidadão.

Porém, evidencia-se, em uma comparação preliminar, que os princípios gerais contidos no Edital do PNLD 2008 são muito mais detalhados e articulados às demandas da sociedade civil organizada do que os demais, sobressaindo-se em relação aos Editais de 2011 e 2014, que aparecem com um viés mais genérico no quesito qualidade desejada e buscada, em que pesem manterem o foco nos ditames da Constituição Federal de 1988.

\section{Papel do Livro Didático:}

\begin{tabular}{|c|c|c|}
\hline Edital 2008 & Edital 2011 & Edital 2014 \\
\hline $\begin{array}{l}\text { [...] o livro deve auxiliar o professor } \\
\text { na busca por caminhos possíveis para } \\
\text { sua prática pedagógica; o livro } \\
\text { didático deve oferecer ao professor } \\
\text { liberdade de escolha e espaço para } \\
\text { que ele possa agregar ao seu } \\
\text { trabalho outros instrumentos; o } \\
\text { livro didático deve atuar, ainda, } \\
\text { como propagador de conceitos e } \\
\text { informações necessários à cidadania } \\
\text { e ao convívio democrático, como o } \\
\text { respeito, a ética, o reconhecimento } \\
\text { da diversidade; o livro didático deve } \\
\text { desempenhar um duplo papel: um } \\
\text { papel social, ao contribuir para a } \\
\text { formação da cidadania, incentivar a } \\
\text { autonomia do professor, valorizar a } \\
\text { liberdade de expressão e } \\
\text { pensamento e promover o respeito }\end{array}$ & $\begin{array}{l}\text { [...] o livro didático deve } \\
\text { veicular informação } \\
\text { correta, precisa, } \\
\text { adequada e atualizada; } \\
\text { desenvolver ativamente as } \\
\text { habilidades envolvidas no } \\
\text { processo de ensino e } \\
\text { aprendizagem; formação } \\
\text { dos alunos como cidadãos } \\
\text { (possam estabelecer } \\
\text { julgamentos, tomar } \\
\text { decisões e atuar } \\
\text { criticamente frente às } \\
\text { questões que a sociedade); } \\
\text { visa a construção da } \\
\text { cidadania; }\end{array}$ & $\begin{array}{l}\text { [...] desenvolver ativamente } \\
\text { as habilidades envolvidas } \\
\text { no processo de ensino e } \\
\text { aprendizagem; formação } \\
\text { dos alunos como cidadãos } \\
\text { (possam estabelecer } \\
\text { julgamentos, tomar decisões } \\
\text { e atuar criticamente frente às } \\
\text { questões que a sociedade); } \\
\text { visa a construção da } \\
\text { cidadania; }\end{array}$ \\
\hline
\end{tabular}




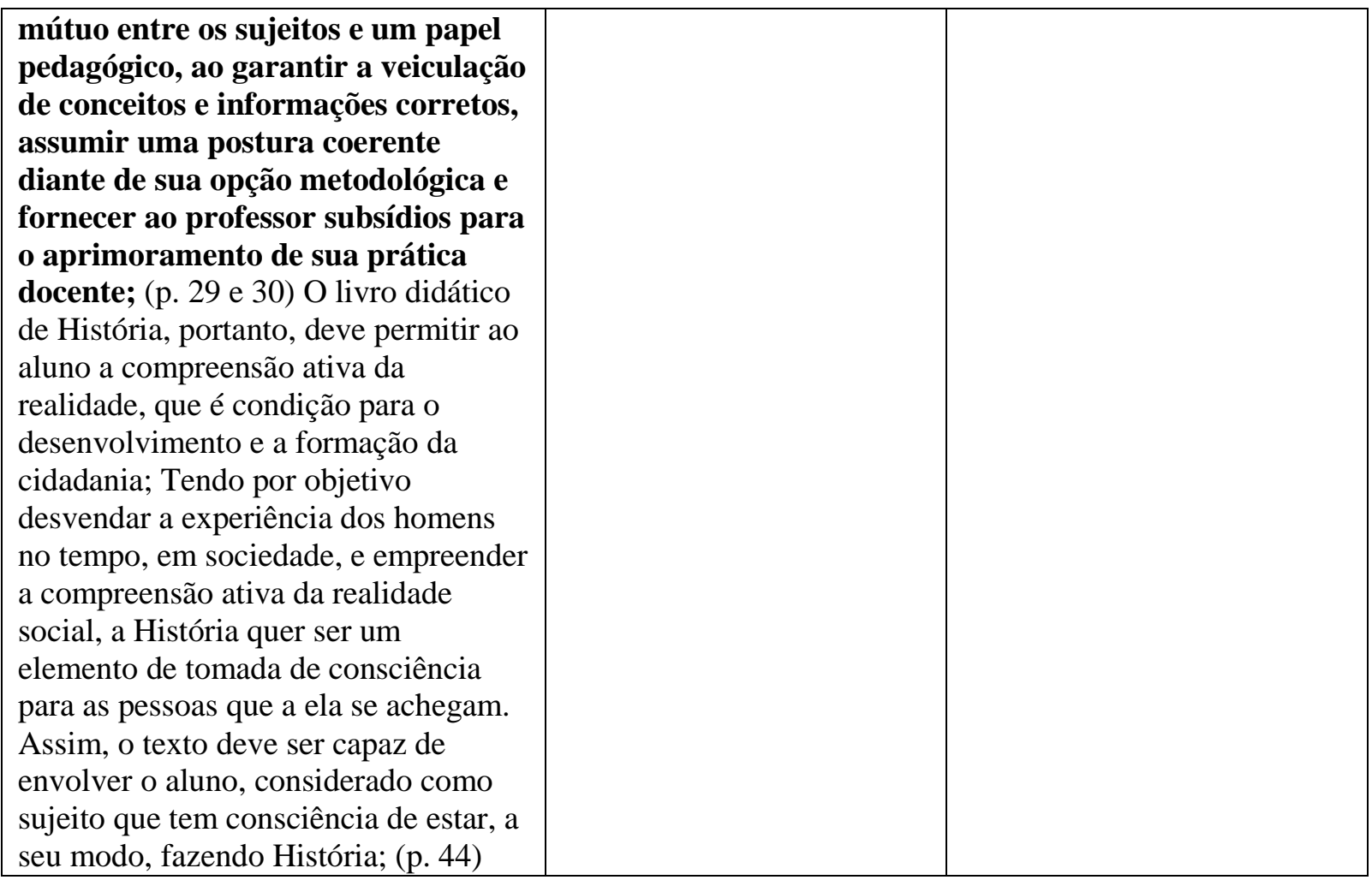

Grifo nosso

Ao analisar esses editais, no intuito de compreender o papel esperado do Livro Didático, observamos uma diferença qualitativa por parte do Edital de 2008 em contraponto a um viés mais genérico nos outros dois. Um conceito bastante evidente nesse Edital é o de autonomia na prática pedagógica que o professor deve desenvolver dentro da sala de aula. Outros conceitos também permeiam o Edital de 2008, tais como diversidade, liberdade, respeito e compreensão da realidade.

Nos demais, 2011 e 2014, nota-se que um texto mais genérico prevalece quando os mesmos atinam somente para a necessidade de o LD veicular informação correta, precisa, adequada e atualizada, bem como a formação dos alunos como cidadãos. Não se detalha como isso deva se dar. Já no Edital de 2008, buscava-se, além do relatado, um material que considerava o aluno como sujeito que tem consciência, a seu modo, do estar a fazer história. 


\section{Sobre a legislação vigente:}

\begin{tabular}{|c|c|c|}
\hline Edital 2008 & Edital 2011 & Edital 2014 \\
\hline $\begin{array}{l}\text { Constituição Federal, Estatuto } \\
\text { da Criança e do Adolescente, } \\
\text { Lei de Diretrizes e Bases da } \\
\text { Educação Nacional, Lei no } \\
\text { 10.639/2003, Diretrizes } \\
\text { Nacionais do Ensino } \\
\text { Fundamental, Resoluções e } \\
\text { Pareceres do Conselho } \\
\text { Nacional de Educação, em } \\
\text { especial, o Parecer CEB } \\
n^{\circ} 15 / 2000 \text {, de } 04 / 07 / 2000 \text {, o } \\
\text { Parecer CNE/CP n } 003 / 2004 \text {, } \\
\text { de } 10 / 03 / 2004 \text { e Resolução n } \\
\text { 1, de } 17 \text { de junho de } 2004 ; \text { (p. } \\
\text { 30) }\end{array}$ & $\begin{array}{l}\text { (i) Constituição da República } \\
\text { Federativa do Brasil. (ii) Lei de } \\
\text { Diretrizes e Bases da Educação } \\
\text { Nacional, com as respectivas } \\
\text { alterações introduzidas pelas } \\
\text { Leis } \mathrm{n}^{\circ} 10.639 / 2003, \mathrm{n}^{\circ} \\
11.274 / 2006, \mathrm{n}^{\circ} 11.525 / 2007 \text { e } \\
\mathrm{n}^{\circ} 11.645 / 2008 \text {. (iii) Estatuto da } \\
\text { Criança e do Adolescente. (iv) } \\
\text { Diretrizes Curriculares } \\
\text { Nacionais para o Ensino } \\
\text { Fundamental. (v) Resoluções e } \\
\text { Pareceres do Conselho Nacional } \\
\text { de Educação, em especial, o } \\
\text { Parecer CEB no } 15 / 2000, \text { de } \\
\text { 04/07/2000, o Parecer CNE/CP } \\
\mathrm{n}^{\circ} 003 / 2004, \text { de } 10 / 03 / 2004 \text { e a } \\
\text { Resolução CNE/CP n } 01 \text { de } \\
\text { 17/06/2004. (p. } 36 \text { e } 37 \text { ) }\end{array}$ & 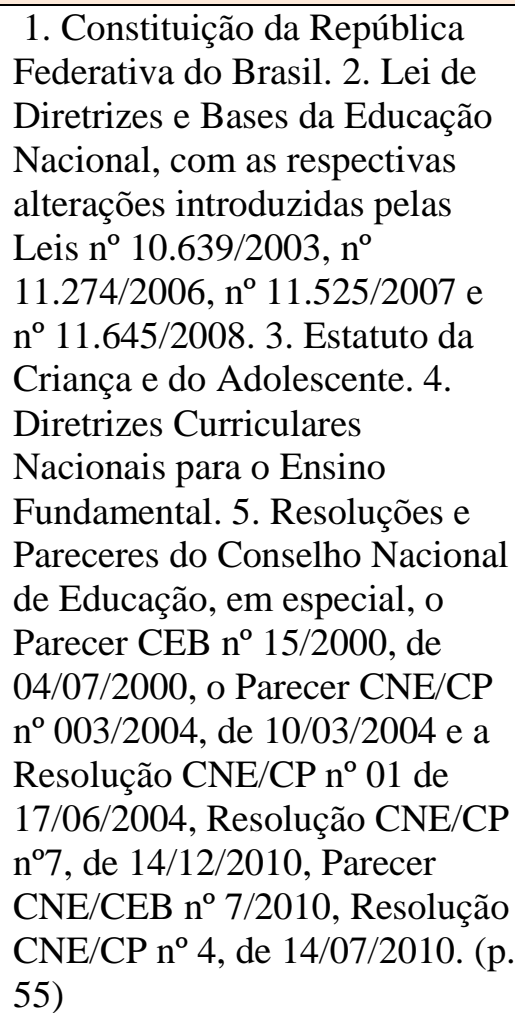 \\
\hline
\end{tabular}

Nota-se do detalhamento em 2008 que a análise dos editais em estudo avança para a parte em que é apresentada a estrutura das leis que regem o processo avaliativo do PNLD. Nesse quesito, não aparecem grandes diferenças no corpo de leis a serem respeitadas.

A Constituição de 1988 é o texto primordial, seguida pela LDB de 1996 e pelas Diretrizes Curriculares Nacionais para o Ensino Fundamental. Nota-se uma tendência mais legalista e menos explicativa à medida que os anos avançam. 


\section{Do objetivo advindo da legislação:}

\begin{tabular}{|c|c|c|}
\hline Edital 2008 & Edital 2011 & Edital 2014 \\
\hline $\begin{array}{l}\text { [...] a avaliação dos livros } \\
\text { didáticos baseia-se, portanto, } \\
\text { na premissa de que o livro } \\
\text { deve auxiliar o professor na } \\
\text { busca por caminhos possíveis } \\
\text { para sua prática pedagógica. } \\
\text { Esses caminhos não são únicos, } \\
\text { posto que o universo de } \\
\text { referências não pode se esgotar } \\
\text { no restrito espaço da sala de } \\
\text { aula ou do livro didático, mas } \\
\text { atuam como uma orientação } \\
\text { importante, até mesmo para que } \\
\text { o professor busque, de forma } \\
\text { autônoma, outras fontes e } \\
\text { experiências para complementar } \\
\text { seu trabalho em sala de aula; }\end{array}$ & $\begin{array}{l}{[\ldots] \text { atende à política de incentivo }} \\
\text { à produção e qualificação de } \\
\text { materiais didáticos no País; que o } \\
\text { livro didático contribua para o } \\
\text { acesso de professores, alunos e } \\
\text { famílias a fatos, conceitos, } \\
\text { saberes, práticas, valores e } \\
\text { possibilidades de compreender, } \\
\text { transformar e ampliar o modo } \\
\text { de ver e fazer a ciência, a } \\
\text { sociedade e a educação; }\end{array}$ & $\begin{array}{l}\text { [...] a formação dos alunos } \\
\text { como cidadãos, de modo } \\
\text { que possam estabelecer } \\
\text { julgamentos, tomar decisões } \\
\text { e atuar criticamente frente às } \\
\text { questões que a sociedade; } \\
\text { construção da cidadania; }\end{array}$ \\
\hline
\end{tabular}

Grifo nosso

É notório que a quantidade de leis vai se ampliando proporcionalmente às explicações conceituais que recuam. Em resumo, pode-se dizer que, considerando os termos do Edital de 2008, o papel do LD deve ser o de auxiliar o professor na busca por caminhos possíveis para sua prática pedagógica autônoma, reconhecendo que esses caminhos não são únicos. A face da autonomia do professor deve prevalecer em sua prática educativa.

Como foco no Edital de 2011, o LD, ao atender à política de incentivo à produção e qualificação de materiais didáticos no País, deveria subsidiar o acesso de professores e alunos ao conhecimento, especialmente ao modo de ver e fazer a ciência, a sociedade e a educação. Já o Edital de 2014 restringe à formação dos alunos como cidadãos. E como visto, as leis tornaramse cada vez mais o norte para atingir a meta pretendida, principalmente o Edital de 2014. 
Objetivo dos critérios de avaliação:

\begin{tabular}{|l|l|l|}
\hline Edital 2008 & Edital 2011 & Edital 2014 \\
\hline $\begin{array}{l}{[\ldots] \text { possibilitando a alunos e }} \\
\text { professores o acesso a } \\
\text { informações corretas e } \\
\text { necessárias ao crescimento } \\
\text { pessoal, intelectual e social } \\
\text { dos atores envolvidos no } \\
\text { processo educativo. }\end{array}$ & $\begin{array}{l}{[\ldots] \text { um padrão consensual }} \\
\text { mínimo de qualidade para o } \\
\text { ensino e, portanto, também, } \\
\text { para as coleções didáticas; }\end{array}$ & $\begin{array}{l}{[\ldots] \text { um padrão consensual }} \\
\text { mínimo de qualidade para o } \\
\text { ensino e, portanto, também, } \\
\text { para as coleções didáticas; } \\
\text { referem-se a requisitos } \\
\text { indispensáveis de qualidade } \\
\text { didático-pedagógica; }\end{array}$ \\
& & \\
\hline
\end{tabular}

Grifo nosso

Ao procurarmos compreender o objetivo dos critérios de avaliação, observamos um foco mais detalhado no texto do Edital de 2008 do que nos demais. No primeiro, busca-se garantir o acesso a informações corretas e necessárias ao crescimento pessoal, intelectual e social dos atores envolvidos no processo educativo. Nos textos de 2011 e 2014, o viés genérico aparece novamente e fala-se em um "padrão consensual mínimo" de qualidade para o ensino, para os LD avaliados e selecionados no âmbito do PNLD. Nota-se que vai se delineando um padrão, que inclusive orienta os objetivos.

Dos critérios comuns de avaliação pedagógica:

\begin{tabular}{|c|c|c|}
\hline Edital 2008 & Edital 2011 & Edital 2014 \\
\hline $\begin{array}{l}\text { (i) correção dos conceitos e } \\
\text { informações básicas; (iii) } \\
\text { observância aos preceitos } \\
\text { legais e jurídicos; (p. } 30 \text { ) }\end{array}$ & $\begin{array}{l}\text { (i) respeito à legislação, às } \\
\text { diretrizes e às normas oficiais } \\
\text { relativas ao ensino } \\
\text { fundamental; (ii) observância } \\
\text { de princípios éticos necessários } \\
\text { à construção da cidadania e ao } \\
\text { convívio social republicano; } \\
\text { (iv) correção e atualização de } \\
\text { conceitos, informações e } \\
\text { procedimentos; }\end{array}$ & $\begin{array}{l}\text { 2.1.1. respeito à legislação, às } \\
\text { diretrizes e às normas oficiais } \\
\text { relativas ao ensino fundamental; } \\
\text { 2.1.2. Observância de princípios } \\
\text { éticos necessários à construção da } \\
\text { cidadania e ao convívio social } \\
\text { republicano; 2.1.4. correção e } \\
\text { atualização de conceitos, } \\
\text { informações e procedimentos; }\end{array}$ \\
\hline
\end{tabular}

Grifo nosso

Nos critérios comuns de avaliação pedagógica, observa-se o viés legalista crescente dando base aos critérios avaliativos contidos no Edital do PNLD, bem como buscando a garantia de LD corretos em seus conteúdos. O grande balizador do Edital nesse contexto são as legislações na área de educação, conforme comentado anteriormente. Daí, notam-se as mudanças subliminares na discussão da avaliação. 


\section{Dos critérios de exclusão:}

\begin{tabular}{|c|c|c|}
\hline Edital 2008 & Edital 2011 & Edital 2014 \\
\hline $\begin{array}{l}\text { [...] uma coleção didática não } \\
\text { poderá, sob pena de descumprir } \\
\text { seus objetivos didático- } \\
\text { pedagógicos: (i) apresentar de } \\
\text { modo errado conceitos, imagens } \\
\text { e informações fundamentais das } \\
\text { disciplinas científicas em que se } \\
\text { baseia; a coleção didática não } \\
\text { poderá: (i) veicular preconceitos } \\
\text { de condição econômico-social, } \\
\text { étnico-racial, gênero, linguagem } \\
\text { e qualquer outra forma de } \\
\text { discriminação; (ii) fazer } \\
\text { doutrinação de qualquer tipo, } \\
\text { desrespeitando o caráter laico e } \\
\text { democrático do ensino público; } \\
\text { (p. } 30 \text { e 31) }\end{array}$ & $\begin{array}{l}\text { • veicularem estereótipos e } \\
\text { preconceitos de condição } \\
\text { social; • fizerem doutrinação } \\
\text { religiosa ou política, } \\
\text { desrespeitando o caráter } \\
\text { laico e autônomo do ensino } \\
\text { público; serão excluídas as } \\
\text { coleções que: I. apresentar } \\
\text { de modo equivocado ou } \\
\text { desatualizado conceitos, } \\
\text { informações e } \\
\text { procedimentos propostos } \\
\text { como objetos de ensino- } \\
\text { aprendizagem; }\end{array}$ & $\begin{array}{l}\text { 1. veicularem estereótipos e } \\
\text { preconceitos; } 2 \text {. fizerem } \\
\text { doutrinação religiosa ou política, } \\
\text { desrespeitando o caráter laico e } \\
\text { autônomo do ensino público; } 1 \text {. } \\
\text { apresentarem, de modo } \\
\text { equivocado ou desatualizado } \\
\text { conceitos, informações e } \\
\text { procedimentos propostos como } \\
\text { objetos de ensino-aprendizagem; }\end{array}$ \\
\hline
\end{tabular}

Quando observamos os critérios de exclusão de LD na avaliação pedagógica, delimitados no Edital de 2008, esses aparecem de maneira mais descritiva em comparação com os de 2011 e 2014, porém a legislação é respeitada.

O texto demonstra, ainda, uma preocupação em detalhar o que seja a qualidade pedagógica do LD e atenta para que a obra não deva conter conceitos, imagens e informações errôneas, além de não poder veicular preconceitos de condição econômico-social, étnico-racial, gênero, linguagem e qualquer outra forma de discriminação, atendendo, assim, à legislação vigente no país consonante a direitos sociais. Também interessante na letra do texto de 2008 é a preocupação em evitar habilitar um LD que faça doutrinação de qualquer tipo, desrespeitando o caráter laico e democrático do ensino público.

Nos editais de 2011 e 2014, o item que mais se evidencia é a proibição do LD de veicular estereótipos e preconceitos de condição social, bem como fazer doutrinação religiosa ou política desrespeitando o caráter laico e autônomo do ensino público. O que fica evidente em ambos os editais é a busca de um material didático que respeita a legislação brasileira vigente, CF de 1988, LDB de 1996 e outras, bem como o interesse de selecionar um material calcado no espírito laico e autônomo do ensino público no País. Entretanto, mais focados na Lei que o de 2008.

Esse critério usado na avaliação dos LD perpassa o foco deste trabalho, e subtende-se que essa orientação estaria evidenciando o que se entende por uma qualidade do material didático, consequentemente, substanciando um ensino de qualidade, que se deve ensinar em 
História em termos didáticos. No conjunto, o Edital 2008 é notoriamente o mais detalhado e comprometido com os pontos da sociedade civil organizada.

\section{Dos critérios de qualificação:}

Da análise comparativa entre os critérios da avaliação pedagógica nos Editais do PNLD 2008, 2011 e 2014 fica notória a grande diferença entre eles - os critérios de qualificação. O item critérios de qualificação só aparece no documento de 2008:

As coleções diferem-se em maior ou menor grau no que diz respeito aos aspectos teórico-metodológicos ou de conteúdo. Para melhor orientar os professores no momento da escolha, são utilizados critérios de qualificação comuns, os quais permitem distinguir, entre si, as coleções selecionadas. São eles: Quanto à construção de uma sociedade cidadã, espera-se que o livro didático: 1) promova positivamente a imagem da mulher, considerando sua participação em diferentes trabalhos e profissões e espaços de poder, reforçando, assim, sua visibilidade; 2) aborde a temática de gênero, da não violência contra a mulher, visando à construção de uma sociedade não sexista, justa e igualitária; 3 ) promova positivamente a imagem de afrodescendentes e descendentes das etnias indígenas brasileiras, considerando sua participação em diferentes trabalhos e profissões e espaços de poder; 4) promova positivamente a cultura afro-brasileira e dos povos indígenas brasileiros, dando visibilidade aos seus valores, tradições, organizações e saberes sociocientíficos; 5) aborde a temática das relações étnico-raciais, do preconceito, da discriminação racial e da violência correlata, visando à construção de uma sociedade antirracista, justa e igualitária.)

(BRASIL, 2008, p. 32)

Nele, estão presentes a preocupação e a necessidade de buscar um LD mais próximo das demandas sociais, principalmente em relação à questão de gênero, ao qualificar um conteúdo que promova positivamente a imagem da mulher, bem como a questão de violência contra a mulher.

Também aborda, de forma mais propositiva, a questão étnico-racial balizada pela Lei 10.639/2003, quando busca, nesse viés, fornecer subsídios para qualificar o livro didático que promova positivamente a imagem de afrodescentes e descendentes das etnias brasileiras.

Essa preocupação em promover positivamente essas demandas sociais em um critério a mais, visível no Edital de 2008 e que nos outros editais deixou de se apresentar, parece-nos uma diferença significativa nos critérios dos editais do PNLD.

Diante do quadro em tela, fica uma questão: poderia essa falta influenciar na qualidade dos LD habilitados pelo programa em suas edições posteriores? 
Também em relação a esse critério de qualificação, é notório que o Edital de 2008 se antecipava a este ou aquele autor, detalhando que o combate ao sexismo e ao racismo deveria estar contemplado nas obras. Nos de 2011 e 2014, apenas mencionam em seus itens as leis a respeito dessas temáticas, o que pressupõe um domínio dos autores sobre os conteúdos da Lei.

O próximo item de análise dos editais delimitados nesta pesquisa são os princípios específicos da área de História.

\section{Dos princípios específicos da área de História:}

\begin{tabular}{|c|c|c|}
\hline Edital 2008 & Edital 2011 & Edital 2014 \\
\hline $\begin{array}{l}\text { O ensino de História para os anos } \\
\text { finais do ensino fundamental pauta- } \\
\text { se primordialmente pelos objetivos } \\
\text { que são, em última análise, os } \\
\text { esforços para propiciar a todos os } \\
\text { alunos a formação básica } \\
\text { necessária para o exercício da } \\
\text { cidadania, auxiliando-os a se } \\
\text { tornarem conscientes de seu papel } \\
\text { na sociedade; Nesse sentido, aos } \\
\text { conteúdos históricos apresentados e } \\
\text { desenvolvidos deverão se somar às } \\
\text { estratégias adequadas que auxiliem } \\
\text { a criar condições de aprendizagem } \\
\text { para o desenvolvimento da } \\
\text { capacidade de compreender a trama } \\
\text { social que caracteriza a sociedade } \\
\text { em que vivemos; O objetivo } \\
\text { central da História escolar é } \\
\text { possibilitar que o aluno aprenda a } \\
\text { pensar historicamente, } \\
\text { compreendendo os diferentes } \\
\text { processos e sujeitos históricos, as } \\
\text { relações que se estabelecem entre } \\
\text { os grupos humanos, nos } \\
\text { diferentes tempos e espaços, } \\
\text { sempre a partir de uma efetiva } \\
\text { dimensão de contemporaneidade. } \\
\text { A História é um processo de } \\
\text { compreensão humana das } \\
\text { diferentes e múltiplas } \\
\text { possibilidades existentes na } \\
\text { sociedade, a partir da experiência } \\
\text { do presente; pressupõe práticas } \\
\text { educativas adequadas às } \\
\text { necessidades sociais e culturais da } \\
\text { sociedade brasileira; garanta } \\
\text { aprendizagens essenciais para a } \\
\text { formação da autonomia, da crítica e } \\
\text { da participação; deve, também, }\end{array}$ & $\begin{array}{l}\text { [...] História como a } \\
\text { representação de fatos } \\
\text { ocorridos, por meio da } \\
\text { interpretação das fontes e } \\
\text { testemunhos; o pensar } \\
\text { historicamente é o objetivo } \\
\text { central do ensino- } \\
\text { aprendizagem de História; } \\
\text { é fundamental a } \\
\text { diferenciação entre a } \\
\text { vivência desses processos e } \\
\text { a forma de produção de } \\
\text { conhecimento sobre eles; } \\
\text { propiciar a diferenciação } \\
\text { entre a vivência desses } \\
\text { processos e a forma de } \\
\text { produção de conhecimento } \\
\text { sobre eles; ensina-se } \\
\text { História como se produz o } \\
\text { conhecimento histórico; Tal } \\
\text { ensino deve ser de } \\
\text { qualidade, ou seja, deve } \\
\text { adequar-se às necessidades } \\
\text { socioculturais da sociedade } \\
\text { brasileira, a legislação } \\
\text { educacional em vigor e com } \\
\text { as tendências científicas } \\
\text { abonadas pela academia; o } \\
\text { livro didático deve } \\
\text { contribuir para o } \\
\text { desenvolvimento dos } \\
\text { conceitos de História; (p. } \\
\text { 46) }\end{array}$ & $\begin{array}{l}\text { [...] História entendida como } \\
\text { representação desses fatos, por } \\
\text { meio da organização, crítica e } \\
\text { interpretação das fontes; } \\
\text { pluralidade teórica que } \\
\text { caracteriza a área; } \\
\text { desconstrução desse senso } \\
\text { comum, que concebe o livro } \\
\text { didático como veiculador de } \\
\text { uma verdade absoluta; } \\
\text { capacidade de compreensão } \\
\text { do processo histórico e da } \\
\text { produção de conhecimento } \\
\text { sobre o mesmo; Viabilizar o } \\
\text { pensar historicamente é o } \\
\text { objetivo central do ensino- } \\
\text { aprendizagem de História; } \\
\text { ensino deve ser de qualidade } \\
\text { (deve adequar-se às } \\
\text { necessidades socioculturais da } \\
\text { sociedade brasileira; respeitar } \\
\text { legislação educacional em } \\
\text { vigor e as tendências } \\
\text { científicas abonadas pela } \\
\text { academia); deve contribuir } \\
\text { para o desenvolvimento dos } \\
\text { conceitos de História; }\end{array}$ \\
\hline
\end{tabular}


colaborar para o despertar de capacidades que auxiliem o aluno a atuar na sociedade em que vive com competência, dignidade e responsabilidade;

Grifo nosso

No edital de 2008, esses critérios aparecem de forma mais abrangente do que nos outros dois, enfatizando-se aí que o ensino de História deve proporcionar aos estudantes a formação básica necessária para o exercício da cidadania, formar o indivíduo consciente de seu papel na sociedade.

Nesse sentido, o material didático habilitado pelo PNLD considera que as obras devem propiciar ao aluno a compreensão da trama social que caracteriza a sociedade em que ele vive e da qual participa. Como entender tal trama social se não houver um posicionamento crítico no conteúdo disponibilizado pelo LD? Um conteúdo "neutro", como apregoa alguns, não respeitaria esse requisito, presente no edital de 2008.

Os princípios e o objetivo estabelecidos no edital de 2008 demonstram a necessidade de que o LD habilitado proporcione ao aluno aprender:

[...] pensar historicamente, compreendendo os diferentes processos e sujeitos históricos, as relações que se estabelecem entre os grupos humanos, nos diferentes tempos e espaços, sempre a partir de uma dimensão de contemporaneidade. (BRASIL, 2005).

O edital de 2008 salienta o papel da história nas práticas educativas que visem à formação da autonomia, da crítica e da participação do educando, do cidadão na sociedade.

No Edital de 2011, os princípios específicos da História observam a intepretação das fontes e o pensar historicamente. O foco são os conceitos da disciplina História, e a qualidade do LD estaria garantida nesse contexto. No Edital de 2014, a qualidade é delimitada por meio do respeito à legislação educacional em vigor e na incorporação das tendências críticas da academia.

O próximo tópico dos editais analisados é nomeado como critérios específicos da área de História. 


\section{Dos critérios específicos da área de História:}

Nesses critérios, sãos trabalhados os elementos avaliativos específicos para o LD de História. No documento de 2008, são apresentados os seguintes critérios de exclusão que o LD deve cumprir: i) correção dos conceitos e das informações básicas não podendo o LD incorrer em anacronismo, voluntarismo e nominalismo; ii) o LD não pode conter erros de informação ou informações desatualizadas; iii) o LD não pode ferir os preceitos éticos, não pode incorrer em nenhum tipo de preconceito.

O anacronismo consiste em atribuir aos agentes históricos do passado razões ou sentimentos gerados no presente. Já o voluntarismo consiste em aplicar a documentos e textos uma teoria, a priori, em função do que se quer demonstrar e, por fim, o nominalismo evidenciase quando a análise proposta abstrai-se de realidades vividas pelos sujeitos históricos, em proveito da mera descrição de quadros jurídicos, regulamentares ou institucionais. Esses três conceitos excludentes aparecem de forma incisiva no edital de 2008.

A grande diferença entre os editais analisados é em relação ao conceito de nominalismo que não aparece nos editais de 2011 e de 2014.

Interessante, que há no Edital de 2008 uma diferenciação do que seja da área, pressupondo como visto uma forma de ensinar e lidar com os fatos e as fontes históricas, com destaque para as relações estabelecidas com os conteúdos históricos e, no último item dos editais analisados, há os critérios de qualificação específicos de História que aparecem somente no documento de 2008.

\section{Dos critérios de qualificação específicos de História:}

Nesses, salienta-se o quesito da atualização, tanto historiográfica quanto pedagógica. Preconiza que o LD de História apresente:

- Atualização historiográfica. Nas últimas décadas, o conhecimento histórico vem ampliando consideravelmente seus horizontes, seja em aspectos teóricometodológicos, seja na descoberta de novos objetos e na proposta de novas interpretações. Assim, torna-se necessário incorporar na elaboração de obras didáticas, de modo efetivo e não apenas na intenção inicial ou na introdução da coleção, pelo menos aquela parte da renovação historiográfica que já se tornou consolidada e que é do consenso de parte significativa dos estudiosos da História, de forma condizente à faixa etária/etapa de desenvolvimento a que se destina.

- Atualização pedagógica. As ideias e práticas pedagógicas têm apresentado inovações no que diz respeito às concepções de educação, escola, processos 
de ensino e aprendizagem, conteúdo, avaliação e, portanto, devem ser incorporadas ao ensino de História por meio do livro didático.

- A problematização do passado e do presente constitui o ponto inicial para a construção de uma História crítica. Toda análise histórica que parte de um problema ou de conjunto de problemas, firma-se nesta convicção. Contudo, não se pode reduzir esta problematização apenas a formulação de perguntas.

(BRASIL, 2008, p. 48 e 49) Grifo nosso

Nos critérios de qualificação do Edital de 2008, também é delimitado o que o LD de História não deve propagar:

- O livro didático não poderá incorporar estereótipos como a identificação exclusiva da História a alguns heróis ou a utilização de caricaturas, de períodos ou de personagens, nem a restrição à memória individual ou de grupos, o que é extremamente nocivo ao ensino de História; É imperioso que evite simplificações explicativas; não é possível a identificação da história narrada a uma verdade absoluta;

(BRASIL, 2008, p. 49)

Os Editais de 2011 e 2014 não trazem mais diretamente referências dessa natureza.

Seguem os principais resultados da comparação entre os editais do PNLD 2008, 2011 e 2014.

\section{Considerações preliminares:}

A observação advinda da sistematização entre as estruturas dos Editais do PNLD nos anos de 2008, 2011 e 2014 para o Ensino Fundamental foi a permanência dos princípios estruturantes tanto na parte geral dos Editais quanto em sua parte particular, os princípios e critérios específicos na área de História, porém os editais de 2011 e 2014 não fazem referência aos critérios específicos de História, e isso chama a atenção.

Uma grande diferença nas categorias analisadas nos Editais foi a supressão dos Critérios de qualificação e Critérios de qualificação específicos de História existentes no Edital de 2008 e não mais presentes nas demais versões de 2011 e 2014. A supressão desses critérios classificatórios pode ter influenciado de maneira diversa a avaliação pedagógica das obras inscritas no PNLD.

Por exemplo, os conceitos tidos como não adequados no Edital de 2008, a saber, os conceitos de "nominalismo" e de "simplificação não explicativa" não puderam mais servir para "classificar" ou "ranquear" uma obra perante outra na avaliação pedagógica. Parece que a 
orientação de 2008 permitiria um maior rigor em se aplicar os critérios. A partir do Edital de 2011, passou-se a ter a perspectiva de selecionar ou não selecionar uma obra sem critérios classificatórios. Uma análise mais aprofundada dos impactos nos LD analisados ficará por ser feita. Por ora, não nos cabe aprofundamentos nesse sentido.

Finda a leitura cuidadosa dos Editais de 2008, 2011 e 2014, passamos a uma leitura crítica do material apresentado. 


\section{CAPÍTULO 3: CONFRONTOS, ENCONTROS E DESENCONTROS NA POLÍTICA DO LIVRO DIDÁTICO}

O Programa Nacional do Livro Didático apresenta em seu discurso oficial o objetivo principal de "avaliar e distribuir obras didáticas de qualidade a alunos e professores das escolas públicas brasileiras de ensino fundamental e de ensino médio". Conforme o Decreto $n^{0} \mathbf{7 . 0 8 4}$, de 27/01/2010, são objetivos gerais do programa:

Art. $2^{\circ}$ São objetivos dos programas de material didático:

I - melhoria do processo de ensino e aprendizagem nas escolas públicas, com a consequente melhoria da qualidade da educação;

II - garantia de padrão de qualidade do material de apoio à prática educativa utilizado nas escolas públicas;

III - democratização do acesso às fontes de informação e cultura;

IV - fomento à leitura e o estímulo à atitude investigativa dos alunos;

$\mathrm{V}$ - apoio à atualização e ao desenvolvimento profissional do professor.

Art. $3^{\circ}$ São diretrizes dos programas de material didático:

I - respeito ao pluralismo de ideias e concepções pedagógicas;

II - respeito às diversidades sociais, culturais e regionais;

III - respeito à autonomia pedagógica dos estabelecimentos de ensino;

IV - respeito à liberdade e o apreço à tolerância; e

$\mathrm{V}$ - garantia de isonomia, transparência e publicidade nos processos de avaliação, seleção e aquisição das obras.

(BRASIL, 2010, p. 1) (Grifo nosso)

Sem a pretensão de avaliar se esse objetivo é ou não materializado no LD, mas como ele se desdobra nos Editais de 2008, 2011 e 2014, o intuito neste capítulo é compreender algumas implicações das acusações feitas ao LD como sendo obras tendenciosas e "partidárias", se há indícios de veracidade em tais acusações e responder à última questão relativa à verificação de como a ideia de qualidade se delineia no PNLD.

\subsection{Análise dos critérios e princípios estabelecidos nos Editais do PNLD que subsidiam a avaliação pedagógica dos Livros Didáticos no programa}

A ideia de qualidade da educação como norteadora do PNLD está presente no Artigo $2^{\circ}$, inciso II do Decreto $\mathrm{n}^{\circ} 7.084$ que estabelece os objetivos dos programas de material didático no sentido de garantir um padrão de qualidade dos livros fornecidos às escolas públicas. Essa qualidade é delineada nas diretrizes estipuladas no Art. $3^{\circ}$, e advoga em favor do respeito ao 
pluralismo de ideias e de concepções pedagógicas. Neste capítulo, interessa-nos observar se a questão do respeito ao pluralismo de ideias está presente nos editais citados e se a equipe avaliadora utiliza os critérios estabelecidos nesses editais.

No capítulo II, já identificamos que há um conjunto de percepções sobre o que existe nos Editais. Isso ficou materializado na "limpeza" que foi feita a partir do Edital de 2011 e culmina em 2014, com termos genéricos e universalistas de cidadão/cidadã, tolerância/diferenças, bem diferente do detalhamento contido no Edital de 2008.

As implicações disso em um país com as dimensões do Brasil e com um quadro de formação de professores tão diverso causa inquietação: saberão como tratar temas invisibilizados como gênero, raça/etnia e relação entre local/global numa perspectiva de temporalidades simultâneas de recuos/avanços e ressignificações? E é esse o interesse?

Vimos que há critérios para a área de História, mas a problematização das correntes historiográficas como critério específico da história, no contraponto com as vivências e conhecimentos prévios dos estudantes, só aparece nitidamente no Edital de 2008.

Assim, por meio de um questionário aberto aplicado aos avaliadores, tentamos ver como eles entendem o conceito de qualidade e se têm a mesma percepção que nós.

Ora, se o principal documento norteador do PNLD, instrumento balizador da avaliação e seleção de LD, o edital, estabelece esse preceito, compreender como o discurso aí se materializa, bem como a forma como a equipe de avaliadores observa e faz cumprir os dispostos dos editais nos ajudará a delinear o que esses sujeitos diretamente envolvidos no processo têm entendido por qualidade. Esse percurso permitirá elucidar se as críticas feitas ao programa são válidas na perspectiva dos avaliadores e se os editais são eficientes em evitar a seleção e distribuição de LD com conteúdos que infrinjam as leis do País.

Segundo ponto: é possível e/ou necessário barrar ou não a seleção de uma obra didática, e em particular, uma obra didática de História que tenha suas próprias ideias e posicionamentos dos autores no campo da História, que também é política, por exemplo? Essas diretrizes são um importante ponto de partida para todas essas discussões.

Avançando nos critérios, princípios e diretrizes norteadores do processo de avaliação e seleção de Livros Didáticos no âmbito do PNLD, tomemos como documento de análise os editais do PNLD 2008, 2011 e 2014 e seus "critérios comuns" em ambos os editais. Esses critérios comuns apresentam os itens com caráter eliminatório. No caso específico do documento de 2008, também trabalhamos com os itens que apresentam o caráter de qualificação. 
Os três documentos citados foram norteadores da avaliação pedagógica das obras didáticas do PNLD no período e no ciclo estudado.

O Edital PNLD 2008 trouxe como "critérios eliminatórios" a obrigatoriedade da:

(i) correção dos conceitos e informações básicas;

(ii) coerência e adequação metodológicas;

(iii) observância aos preceitos legais e jurídicos (Constituição Federal, Estatuto da Criança e do Adolescente, Lei de Diretrizes e Bases da Educação Nacional, Lei $n^{\circ} 10.639 / 2003^{16}$, Diretrizes Nacionais do Ensino Fundamental, Resoluções e Pareceres do Conselho Nacional de Educação, em especial, o Parecer CEB n ${ }^{\circ} 15 / 2000^{17}$, de 04/07/2000, o Parecer CNE/CP n ${ }^{\circ}$ 003/2004 ${ }^{18}$, de 10/03/2004 e Resolução $n^{\circ} 1^{19}$, de 17 de junho de 2004).

(BRASIL, 2005, p. 30)

E prima por "Preceitos éticos":

Em respeito à Constituição do Brasil e para contribuir efetivamente para a construção da ética necessária ao convívio social e à cidadania, a coleção didática não poderá:

(i) veicular preconceitos de condição econômico-social, étnico-racial, gênero, linguagem e qualquer outra forma de discriminação;

(ii) fazer doutrinação de qualquer tipo, desrespeitando o caráter laico e democrático do ensino público;

(iii) utilizar o material escolar como veículo de publicidade e difusão de marcas, produtos ou serviços comerciais.

(BRASIL, 2005, p. 31 e 32)

Com os critérios de qualificação, o Edital de 2008 espera "distinguir, entre si, as coleções selecionadas", visando um LD com maior qualidade, uma obra que possibilite a "construção de uma sociedade cidadã". Nesse sentido, estabelece que o livro didático:

1) promova positivamente a imagem da mulher, considerando sua participação em diferentes trabalhos e profissões e espaços de poder, reforçando, assim, sua visibilidade;

2) aborde a temática de gênero, da não violência contra a mulher, visando à construção de uma sociedade não sexista, justa e igualitária;

\footnotetext{
${ }^{16}$ A Lei n ${ }^{\circ}$ 10.639/2003 trata da obrigatoriedade do ensino sobre História e Cultura Afro-Brasileiras, contemplando o estudo da História da África e dos Africanos, a luta dos negros no Brasil, a cultura negra brasileira e o negro na formação da sociedade nacional, valorizando o negro nas áreas social, econômica e política pertinentes à História do Brasil. Brasil, 2005.

${ }^{17}$ O parecer CEB no 15/2000 trata da pertinência do uso de imagens nos livros didáticos. Imagens comerciais identificadas, voltadas diretamente para finalidades comerciais propriamente ditas, não devem figurar em livros didáticos no âmbito do PNLD do MEC. O mesmo se aplica aos livros cujos conteúdos expressem imagens e textos discriminatórios e preconceituosos. Brasil, 2000.

${ }^{18} \mathrm{O}$ parecer CNE/CP n ${ }^{\circ}$ 003/2004 institui as Diretrizes Curriculares Nacionais para a Educação das Relações Étnico-Raciais e para o Ensino de História e Cultura Afro-Brasileira e Africana, a serem observadas pelas instituições de ensino de Educação Básica, bem como na Educação Superior. Brasil 2004.

${ }_{19}$ A Resolução no 1, de 17 de junho de 2004, institui as Diretrizes Curriculares Nacionais para a Educação das Relações Étnico-Raciais e para o Ensino de História e Cultura Afro-Brasileira e Africana. Brasil, 2004.
} 
3) promova positivamente a imagem de afrodescendentes e descendentes das etnias indígenas brasileiras, considerando sua participação em diferentes trabalhos e profissões e espaços de poder;

4) promova positivamente a cultura afro-brasileira e dos povos indígenas brasileiros, dando visibilidade aos seus valores, tradições, organizações e saberes sociocientíficos;

5) aborde a temática das relações étnico-raciais, do preconceito, da discriminação racial e da violência correlata, visando à construção de uma sociedade antirracista, justa e igualitária.

(BRASIL, 2005, p. 32)

O estudo desses critérios, presentes no documento de 2008, permite observar a ênfase no objetivo de se ter um LD com correção dos conceitos e informações básicas, bem como sua coerência e adequação metodológicas e a observância aos preceitos legais e jurídicos, conforme elencado no texto do edital. Esses preceitos caracterizam a qualidade que o material didático deve ter para poder ser adquirido e distribuído às escolas públicas do País.

Os critérios delimitados no tópico "Preceitos éticos" ajuda-nos a observar a preocupação do texto do edital em garantir um LD que não cometa proselitismo de qualquer natureza; a ênfase é obter uma obra didática que respeite o caráter laico e democrático do ensino público.

No edital de 2008, apresenta-se o item “critérios de qualificação" que, no entendimento do MEC à época, serviria para aprimorar o entendimento técnico-pedagógico das obras, quando da escolha dos professores das opões contidas no Guia do Livro Didático disponibilizado. Diante do exposto, pode-se dizer que os critérios de qualificação visavam um produto que promovesse a construção de uma sociedade cidadã, uma imagem positiva da mulher, que abordasse a temática de gênero e da não violência contra a mulher, bem como promovesse positivamente a imagem de afrodescendentes e descendentes das etnias indígenas brasileiras. Visava-se um LD sem preconceitos de qualquer natureza.

Já no Edital PNLD 2011, como visto, o foco maior era o respeito à legislação, às diretrizes e às normas oficiais relativas ao ensino fundamental, voltado para à construção da cidadania e o convívio social republicano. (BRASIL, 2008, p. 36).

Esses critérios eliminatórios comuns a todas as áreas são detalhados e complementados no desenvolvimento do próprio Edital, posto que no item 2.1.1 é apresentado o corpo legislativo balizador do Edital, mas não com o grande detalhamento do Edital de 2008.

No Edital de 2011, restringe-se a elencar a legislação, as diretrizes e as normas oficiais que regulamentam o ensino fundamental:

(i) Constituição da República Federativa do Brasil. 
(ii) Lei de Diretrizes e Bases da Educação Nacional, com as respectivas alterações introduzidas pelas Lei $\mathrm{n}^{\mathrm{o}} 10.639 / 2003, \mathrm{n}^{\mathrm{o}} 11.274 / 2006^{20}, \mathrm{n}^{\mathrm{o}}$ $11.525 / 2007^{21}$ e n ${ }^{\mathrm{o}} 11.645 / 2008^{22}$.

(iii) Estatuto da Criança e do Adolescente.

(iv) Diretrizes Curriculares Nacionais para o Ensino Fundamental.

(v) Resoluções e Pareceres do Conselho Nacional de Educação, em especial, o Parecer CEB no 15/2000, de 04/07/2000, o Parecer CNE/CP n 003/2004, de 10/03/2004 e a Resolução CNE/CP n 01 de 17/06/2004.

(BRASIL, 2008, p. 37)

Toda a elaboração voltada para uma educação antirracista e antissexista, cuidadosamente trabalhada em 2008, aparece no item 2.1.2 como critérios de exclusão:

- Veicularem estereótipos e preconceitos de condição social, regional, étnicoracial, de gênero, de orientação sexual, de idade ou de linguagem, assim como qualquer outra forma de discriminação ou de violação de direitos;

- Fizerem doutrinação religiosa ou política, desrespeitando o caráter laico e autônomo do ensino público;

Utilizarem o material escolar como veículo de publicidade ou de difusão de marcas, produtos ou serviços comerciais.

(BRASIL, 2008, p. 37)

Nota-se no documento de 2011 uma preocupação em excluir obras didáticas que "fizerem doutrinação religiosa ou política, desrespeitando o caráter laico e autônomo do ensino público.” Importante balizador para nortear a análise do PNLD.

A questão é: nota-se um vetor que comprova a eficiência do Edital do PNLD no sentido de garantir a questionada "qualidade" ou seria mais um formalismo do dispositivo legal?

O item de exclusão 2.1.3 do Edital de 2011 em seu preceito de "favorecer o desenvolvimento de capacidades básicas do pensamento autônomo e crítico, no que diz respeito aos objetos de ensino-aprendizagem propostos" (BRASIL, 2008, p. 37) nos remete às indagações iniciadas nas considerações iniciais e no capítulo 1.

Quando se atenta para o pensamento autônomo e crítico, estamos a projetar um tipo de emancipação do educando? O Livro Didático de História parece ser uma ferramenta nesse intento.

\footnotetext{
${ }^{20}$ Esta lei altera a redação dos artigos 29, 30, 32 e87 da Lei no 9.394, de 20/12/1996, que estabelece as diretrizes e bases da educação nacional (LDB), dispondo sobre a duração de 9 (nove) anos para o ensino fundamental, com matrícula obrigatória a partir dos 6 (seis) anos de idade. Brasil, 2006.

${ }^{21}$ A Lei $n^{\circ} 11.525$, de 25/09/2007 acrescente o $§ 5^{\circ}$ ao artigo 32 da Lei ${ }^{\circ} 9.394$ (LDB) DE 1996, para incluir conteúdo que trate dos direitos das crianças e dos adolescentes no currículo do ensino fundamental. Brasil, 2007.

${ }^{22}$ A Lei $n^{\circ} 11.645$, de 10/03/2008 altera a LDB (1996) modificada pela Lei ${ }^{\circ} 10.639$ (2003), que estabelece as diretrizes e bases da educação nacional para incluir no currículo oficial da rede de ensino a obrigatoriedade da temática "História e Cultura Afro-Brasileira e Indígena”. Brasil, 2008.
} 
Mas como vimos no capítulo 2, há no Edital de 2011 uma ausência de detalhamento articulado às pesquisas mais recentes no campo da história, como vimos no Edital de 2008, porém a Lei 10.639 de 2003, o Parecer CNE/CP nº 003/2004, a Resolução 001/2004 e a Lei 11.645/2008 foram todos destrinchados e com riqueza de orientação em relação à população negra e à cultura afro-brasileira. O Edital do PNLD 2011 prende-se à letra da lei.

Com relação ao salientado por Ferreira e Franco (2008) de que uma "produção de materiais irregulares do ponto de vista historiográfico" ainda continuaria a acontecer, o item 2.1.4 é claro no sentido de que uma obra deve ser excluída quando apresentar de modo equivocado ou desatualizado conceitos, informações e procedimentos propostos como objetos de ensino-aprendizagem, assim como utilizar de modo equivocado ou desatualizado esses mesmos conceitos e informações, em exercícios, atividades, ilustrações ou imagens (BRASIL, 2008, p. 38).

Este item orientador, pela sua dimensão, é passível de interpretações contraditórias. Por exemplo, estudos mostram que a questão racial vem sendo ressignificada, e essas reelaborações oficiais não são objeto de cursos de formação de professores em todo o Brasil (GARCIAFILICE, 2011).

Também demanda atenção a análise de conteúdo no dispositivo usado para avaliar e selecionar o conteúdo do Manual do Professor. Esse volume constituinte do que se chama, no próprio Edital do PNLD, a coleção didática, formada pelo volume destinado ao aluno e pelo volume destinado ao professor. O Manual do professor deve passar pelo mesmo rigor avaliativo pelo qual passa o Livro do Aluno.

Segundo o item de exclusão 2.1.5 do Edital PNLD 2008, o Manual do professor deve induzir os docentes à reflexão sobre sua prática, bem como contribuir com a emancipação crítica do aluno. Como critério de qualidade:

O Manual do Professor deve visar, antes de mais nada, a orientar os docentes para um uso adequado da coleção, constituindo-se, ainda, num instrumento de complementação didático-pedagógica e atualização para o docente. Nesse sentido, o Manual deve organizar-se de modo a propiciar ao docente uma efetiva reflexão sobre sua prática.

Deve, ainda, colaborar para que o processo de ensino-aprendizagem acompanhe avanços recentes, tanto no campo de conhecimento do componente curricular da coleção, quanto no da pedagogia e da didática em geral.

Considerando-se esses princípios, serão excluídas as coleções cujos Manuais não se caracterizarem por: 
1. explicitar os objetivos da proposta didático-pedagógica efetivada pela coleção e os pressupostos teórico-metodológicos por ela assumidos;

2. descrever a organização geral da coleção, tanto no conjunto dos volumes quanto na estruturação interna de cada um deles;

3. relacionar a proposta didático-pedagógica da coleção aos principais documentos públicos nacionais que orientam o ensino fundamental no que diz respeito ao componente curricular em questão;

4. discutir o uso adequado dos livros, inclusive no que se refere às estratégias e recursos de ensino a serem empregados;

(BRASIL, 2008, p. 38 e 39)

Um elemento importante a ser considerado, que vincula qualidade, formação e o fazer em sala de aula, articula-se à interdisciplinaridade:

5. indicar as possibilidades de trabalho interdisciplinar na escola, a partir do componente curricular abordado na coleção;

6. discutir diferentes formas, possibilidades, recursos e instrumentos de avaliação que o professor poderá utilizar ao longo do processo de ensinoaprendizagem;

7. propiciar a reflexão sobre a prática docente, favorecendo sua análise por parte do professor e sua interação com os demais profissionais da escola;

8. apresentar textos de aprofundamento e propostas de atividades complementares às do livro do aluno.

(BRASIL, 2008, p. 39)

O Edital PNLD 2014 segue o mesmo ritmo e destaca o respeito à legislação, às diretrizes e às normas oficiais relativas ao ensino fundamental, necessários à construção da cidadania e ao convívio social republicano. (BRASIL, 2011, p. 55). Também foca na legislação, nas diretrizes e nas normas oficiais sem maior aprofundamento.

Diante do quadro, chegamos a algumas considerações em relação ao Edital de 2014. Há uma preocupação no documento com a qualidade didático-pedagógica dos LD que forem considerados aptos a serem distribuídos às escolas públicas do País.

O texto legal observa que esse material didático deva respeitar a legislação vigente no País, deva observar os princípios éticos necessários à construção da cidadania e ao convívio social republicano, bem como a correção e atualização de conceitos. Nesse edital, serão excluídas do processo do PNLD obras que veicularem estereótipos e preconceitos, bem como fizerem doutrinação religiosa ou política, desrespeitando o caráter laico e autônomo do ensino público. Requisito também presente nos editais anteriores, tanto no de 2008 quanto no de 2011, conforme demonstrado.

A questão é: o que está prescrito é materializado? Como vimos, essa pergunta é capciosa, pois existem vários aspectos estruturais a serem considerados, em particular a base, a formação dos professores para fazer uso das produções mais recentes. Entretanto, aqui optamos 
por questões objetivas, por ouvir os avaliadores. Mas antes disso, precisamos verificar qual o papel delegado ao LD.

\subsection{O Livro Didático segundo o Decreto Lei ${ }^{0} 7.084$ de 2010}

O artigo $2^{\circ}$ do Decreto 7.084 de 2010 anteriormente citado evidencia a preocupação do Estado para com uma política de educação de qualidade. Essa preocupação fica latente no texto legal, tanto no que reporta à ação educativa quanto no que diz respeito ao material didático a ser disponibilizado para a comunidade escolar. Em seu artigo $3^{\circ}$, traz que o material didático deve respeitar os valores do pluralismo, respeito às diversidades, respeito à autonomia pedagógica do ensino, bem como o respeito à liberdade e o apreço à tolerância.

Após a análise comparativa feita, parece-nos que o Edital do PNLD 2008 foi o que mais detalhou o percurso a ser trilhado no próprio Edital.

O capítulo IV desse Decreto trata do procedimento de avaliação, seleção e aquisição dos LD. Consta do artigo 14 que:

[...] a avaliação pedagógica das obras será realizada por instituições de educação superior públicas, de acordo com as orientações e diretrizes estabelecidas pelo Ministério da Educação, a partir das especificações e critérios fixados no edital correspondente.

(BRASIL, 2010)

Como observamos na análise comparativa, princípios de respeito e cumprimento ao que preconiza o arcabouço legal vigente no País estão presentes em todos os editais do programa. Entretanto, dada sua natureza histórica pertinente ao campo do conhecimento, História, as orientações são passíveis de ser lidas de maneiras diversas, em conformidade com a orientação teórico-metodológica do autor.

Em relação à equipe avaliadora, pressupõe-se que seja formada por pesquisadores do campo História, bem como atuantes no campo de ensino da História. Esses avaliadores devem ser os mais qualificados para avaliar se as obras inscritas no PNLD estão alinhadas com a legislação mais recente para a educação básica, no que se refere a critérios democráticos e cidadãos.

Quanto ao processo de escolha do LD, no âmbito da instituição escolar, o referido Decreto estipula que: 
Art. 23 O Ministério da Educação elaborará o Guia de Livros Didáticos para distribuição às escolas beneficiárias do PNLD, contendo a relação de obras aprovadas e suas respectivas resenhas, a fim de auxiliar os professores na escolha dos livros a serem adotados.

Art. 24 Os livros didáticos serão livremente escolhidos pela escola, por meio de seu corpo docente e dirigente, em primeira e segunda opção para cada componente curricular, considerando-se a adequação e a pertinência das obras em relação à proposta pedagógica de cada instituição escolar.

(BRASIL, 2010)

Os critérios de seleção das obras nas escolas não compõem este estudo. Basta dizer que o papel esperado do Livro Didático de História, conforme parâmetros estabelecidos nos Editais do PNLD nos anos de 2008, 2011 e 2014, é que esse material seja "propagador de conceitos e informações necessárias à cidadania e ao convívio democrático" (Brasil, 2005, p. 29), além de possibilitar ao aluno a "compreensão ativa da realidade, que é condição para o desenvolvimento e a formação da cidadania" (Brasil, 2005, p. 44), com o objetivo de "desvendar a experiência dos homens no tempo, em sociedade, empreender a compreensão ativa da realidade social" (Brasil, 2005, p. 44).

Nesse caso, o papel das equipes de avaliação pedagógica é essencial, postas as várias interpretações sobre temas como o negro, a mulher, gênero, ensino especial, aspectos da História contemporânea desconhecidos do grande público e de muitos dos educadores, em virtude ainda da fragilidade no campo da formação para o ensino de História (GARCIAFILICE, 2011).

A partir da interpretação da legislação explicitada pelo próprio Edital, bem como, a partir dos princípios estipulados no Decreto $\mathrm{n}^{\circ} 7.084$ de 2010, que visam uma qualidade do L.D. para uma educação cidadã, a resposta encaminha-se para o oposto de uma suposta neutralidade do conhecimento histórico nos livros didáticos.

Preocupar-se em selecionar um material didático que contenha ferramentas conceituais que possam servir a uma formação crítica da realidade social, e consequentemente política no aluno, parece ser um objetivo que garanta um LD de qualidade para uma educação de qualidade.

Neste mesmo Edital, o de $2008^{23}$, fala-se em sujeito histórico, o aluno como "sujeito que tem consciência de estar, a seu modo, fazendo História” (Brasil, 2005, p. 44). Ou seja, um aluno que compõe a construção do conhecimento, capaz de, a partir do conteúdo da ferramenta LD e da mediação do professor em sala de aula, saber se posicionar diante da sociedade e da

\footnotetext{
${ }^{23}$ O Edital do PNLD 2008 foi confeccionado e publicado em 2005.
} 
história em seu tempo presente. E, de forma crítica, autônoma, articular presente-passado, ratificando, assim, o que se espera dessa ferramenta: a formação do cidadão.

Nos três editais, o papel do Livro Didático como instrumento que visa formar cidadãos está claro. Espera-se um pensamento crítico, uma atuação autônoma no sentido de seu posicionamento no âmbito da sociedade brasileira, com vistas à sua transformação.

Como visto, o PNLD articula-se com a legislação educacional mais recente. Temas recentes exigem formação e posicionamento crítico, daí a avaliação da qualidade ser feita por uma equipe composta por profissionais qualificados de instituições de ensino superior. A partir disso, o próximo e final item: o que pensam os avaliadores do PNLD?

\subsection{O que pensam os avaliadores sobre os Editais do PNLD de 2008, 2011 e 2014}

Esta pesquisa teve como objeto o Programa Nacional do Livro Didático (PNLD) e como o objetivo geral analisar e caracterizar qual conceito de qualidade permeia a legislação em educação, especificamente como esse conceito se materializou nos Editais do PNLD 2008, 2011 e 2014 através da concepção dos avaliadores pedagógicos do programa.

$\mathrm{O}$ intuito foi responder à questão: Em que medida os livros didáticos de História selecionados e ofertados pelo MEC às escolas públicas do País atendem ao conceito de qualidade contido nos Editais?

Realizamos uma pesquisa de caráter qualitativo e optamos por fazer uso da aplicação de questionários abertos a esses avaliadores. Com o intuito de colhermos repostas acerca do tema pesquisado e seguindo as questões norteadoras explicitadas no quadro VI deste trabalho, o questionário aberto foi aplicado junto às equipes de avaliação pedagógica de História participantes do PNLD 2008, 2011 e 2014. O modelo completo do questionário segue em anexo.

Este questionário foi enviado ao polo de avaliação dirigido pela Universidade Federal do Rio Grande do Norte/UFRN, nos meses de maio a junho de 2015, via e-mail, para 50 pessoas. Obtivemos 13 questionários respondidos assim caracterizados: 
Quadro 5 - Perfil dos avaliadores

\begin{tabular}{|c|c|c|c|c|c|c|}
\hline \multicolumn{7}{|c|}{ Questionário enviado aos avaliadores do PNLD 2008, 2011 e 2014 } \\
\hline Avaliador & Instituição & PNLD 2008 & PNLD 2011 & PNLD 2014 & $\begin{array}{c}\text { Liberação } \\
\text { dos dados }\end{array}$ & $\begin{array}{c}\text { Exigiu } \\
\text { Sigilo }\end{array}$ \\
\hline 1 & UNIR & & & $X$ & SIM & SIM \\
\hline 2 & UECE & $X$ & $X$ & $X$ & SIM & NÃO \\
\hline 3 & UFES & $X$ & $X$ & $X$ & SIM & NÃO \\
\hline 4 & UFPR & & $X$ & $X$ & SIM & NÃO \\
\hline 5 & UFRN & & & $X$ & SIM & SIM \\
\hline 6 & UFRN & & & $X$ & SIM & SIM \\
\hline 7 & UFRN & $X$ & & & SIM & SIM \\
\hline 8 & UFSC & $X$ & $X$ & $X$ & SIM & NÃO \\
\hline 9 & UCDB & $X$ & $X$ & & SIM & NÃO \\
\hline 10 & não inf. & & & $X$ & SIM & NÃO \\
\hline 11 & UFF & $X$ & $X$ & $X$ & SIM & NÃO \\
\hline 12 & UFU & $X$ & $X$ & $X$ & SIM & NÃO \\
\hline 13 & UFRGS & & & $X$ & SIM & NÃO \\
\hline
\end{tabular}

Devido à solicitação de sigilo por parte dos entrevistados, doravante, nomearemos os mesmos como avaliador 1, avaliador 2, avaliador 3 e assim até completar os 13 avaliadores que responderam os questionários. A seguir, a análise de dados a partir das respostas fornecidas pelos avaliadores participantes.

\section{Questão I (Como você compreende o conceito de qualidade do LD exposto no Edital do PNLD?)}

A primeira questão tinha como premissa observar se o conceito de Qualidade do Livro Didático exposto nos Editais está de acordo com o arcabouço teórico recente desenvolvido pela área de História. Dos 13 questionários respondidos, 12 respostas indicaram satisfatoriedade com a definição de qualidade que o LD deve ter para ser habilitado dentro do processo de avaliação pedagógica do programa.

Para o avaliador 1, o LD deve apresentar as seguintes características que atestam a qualidade desejada:

Compreendo o conceito de qualidade no Edital a partir de três elementos básicos, quais sejam: um livro didático deve ter qualidade para ser utilizado como recurso didático no processo de ensino-aprendizagem e, com tal, ele precisa dispor de estratégias pedagógicas que possibilitem desenvolver 
habilidades e competências, as quais facilitem a mediação e a interação entre o professor, o estudante e a vivência escolar; a qualidade de uma obra se manifesta também na possibilidade de servir positivamente à ciência ou área de referência, visto que tal obra será utilizada como instrumento problematizador à construção de saberes específicos, do chamado conhecimento escolar em determinado campo; por fim, uma obra didática, independente da área, precisa ser um instrumento que leve à reflexão propositiva e qualificada a respeito de questões que estão postas na sociedade e visem à formação para consolidação dos direitos e da cidadania.

(Avaliador 1, 2015)

Os avaliadores $2,3,5,7,8,9,10,11$ e 12 observam o conceito de qualidade desejado em um LD a partir do respeito à legislação em vigor, bem como aquele LD que atende às exigências do Edital do PNLD, atentando para seus critérios de exclusão:

Compreendo qualidade no âmbito de um livro didático que respeita a legislação do país, sendo, portanto, isento de anacronismos, de simplificações explicativas, de indução ao preconceito e discriminação. Um livro didático que valorize as diversidades sociais, que dê visibilidade positiva às mulheres, crianças, negros, indígenas e idosos.

(Avaliador 2, 2015) Grifo nosso.

No meu entender, livro de qualidade é aquele que atende às exigências do edital, compreendendo que as mesmas não se configuram como mais e novos conteúdos, que devem ser enxertados nos velhos produtos. Trata-se de uma nova proposta de ensino, que tome em consideração a realidade e os conhecimentos prévios dos alunos, que objetive a formação cidadã (o que significa contribuir para o desenvolvimento de pensamento autônomo, crítico e criativo), que supere a compartimentação artificial do conhecimento produzida pelas lutas no âmbito acadêmico, que parta de escolhas teóricometodológicas e didático-pedagógicas, definidas de forma clara e objetiva, evidenciando como elas contribuem para a consecução dos objetivos em jogo.

(Avaliador 5, 2015) Grifo nosso.

Avalio que o conceito de qualidade do livro didático esteja relacionado principalmente ao atendimento das finalidades gerais dispostas na legislação educacional brasileira, o que inclui, principalmente, o apoio dos conteúdos apresentados nos livros didáticos no difícil processo de passagem do indivíduo a cidadão, por meio da aquisição de conhecimentos básicos necessários ao exercício da cidadania. Assim, dado o caráter democrático da sociedade e do Estado brasileiro, é importante que as coleções didáticas veiculem conteúdos que observem os princípios éticos fundamentais para a construção da cidadania e para o convívio social republicano, mas, também, possam conter propostas teórico-metodológicas diversas, ainda que coerentes no interior de cada obra ou coleção. Por fim, há necessidade de os livros didáticos terem boa qualidade editorial e boa durabilidade.

(Avaliador 12, 2015) Grifo nosso

Considero o conceito muito adequado, porque ultrapassou o limite da mera verificação se o livro possui propaganda, estereótipo ou coisas do tipo. A 
avaliação, hoje, estuda profundamente o livro, do ponto de vista teórico e pedagógico.

(Avaliador 13, 2015)

Para o avaliador 4, a qualidade de um LD se refere ao papel que esse material deveria ter para a formação continuada do professor:

Um bom livro didático de História dever auxiliar na formação de professor, por isso deve ter um manual do professor com textos complementares, discutindo metodologias de ensino de História e historiografia, com um componente curricular que contribua para a compreensão que ensinar História é também ensinar a forma com que esse conhecimento é produzido. Para isso, deve trabalhar com noções e conceitos históricos.

(Avaliador 4, 2015) Grifo nosso

O Avaliador 6 considera satisfatório o conceito de qualidade do LD no âmbito do PNLD, porém problematiza seu ethos:

Considero satisfatório. Qualquer contradição apresentada é o preço que se paga na elaboração de políticas públicas feitas coletivamente. Conceitos são ferramentas intelectuais para leitura das realidades, mas estas sempre escapam. Se você vai na literatura educacional, a ideia de "qualidade" comporta muita coisa, desde noções mais burocráticas até outras estruturalmente utópicas. Nas políticas educacionais elas se sobrepõem.

(Avaliador 6, 2015) Grifo nosso

No geral, os avaliadores pedagógicos do programa concordam que os critérios eliminatórios e específicos do Edital do PNLD são satisfatórios, a saber: o respeito à legislação em educação vigente no país, o foco que se espera na formação cidadã do educando, o conceito e as metodologias adequadas a serem aplicadas nos LDs, conforme estipulados no Edital do PNLD.

Questão II (Você acredita que haja ideologias propagadas no LD de História participante do PNLD?)

Passemos à segunda questão que, aplicada, tinha como objetivo obter feedback a respeito do que o grupo entendia como Ideologia no contexto do PNLD. 
No conjunto, 05 desses avaliadores problematizam o conceito de Ideologia, bem como sua presença no LD e no Edital. Diferenciam o conceito de Ideologia como propaganda política e Ideologia enquanto visão de mundo:

Esse é um ponto bastante delicado e a formulação dele precisa ser melhor delimitada. Ideologia é um conceito que envolve muitas definições e operar com ele é bastante escorregadio. A forma como lemos e dizemos o mundo é mediada pelas ideias que temos sobre como devem e/ou como não devem ser determinadas questões ou relações. Essas ideias, por sua vez, fazem parte do próprio edital e norteiam o que se espera de uma obra didática. Tentando ser mais claro: se entendermos ideologia no sentido de propaganda partidária, comercial, religiosa etc., acredito que este tem sido um campo nos quais os últimos editais e, por conseguinte, as obras aprovadas avançaram bastante e tem se evitada a recorrência dela. Mas se entendido no campo dos valores, a questão toma outros rumos. Isso evidencia-se no fato da construção e aplicação dos editais se situarem em determinada sociedade que busca atender também demandas colocadas pelos homens e mulheres de seu tempo. Assim, notam-se no edital pontos que direcionam as obras para determinadas perspectivas/valores, a exemplo da construção de uma sociedade mais igualitária, mais justa e que combata preconceitos e discriminações de toda ordem. Essas questões são geralmente - mas não totalmente - consensuais e carregam consigo demandas históricas de vários movimentos socais e estamentos organizados da sociedade civil. Ao serem incorporadas em editais, esses valores se fazem, positivamente, presentes. Logo, a neutralidade que se contraporia a priori contra determinadas leituras ideológicas da experiência humana, não é matéria totalmente presente nesses editais, os quais devem, entendo, encaminhar e apontar, sim, determinadas posturas, caminhos e valores que não propagandas, mas que são mediados pelas ideias que fazemos, projetamos da sociedade que se esperar construir por meio da prática educativa.

(Avaliador 1, 2015) Grifo nosso

Se com ideologia você está querendo dizer "inculcação" ou "proselitismo" a resposta é negativa. O encontro de formação em que recebemos orientações sobre como trabalhar é bastante claro no sentido de estar bastante atendo a qualquer possibilidade de desrespeito ao caráter republicano e laico da escolar brasileira ou mesmo a desconsideração da história enquanto prática social e não como verdade absoluta. Mas acho que ideologia no sentido de "visão de mundo" permeia a qualquer objeto da cultura, incluindo o livro didático. Acho que a preocupação no PNLD não é com a presença da ideologia em si e sim os usos que o livro faz dela.

(Avaliador 6, 2015) Grifo nosso

Sim. Todo livro, todo artigo, toda produção científica é pautada em alguma ideologia. Não acredito na isenção ideológica. No entanto, o PNLD vem sistematicamente eliminando estas obras do Guia que façam opções ideológicas e professem essa opção.

(Avaliador 8, 2015) Grifo nosso 
Notam-se quatro formas de "agir" ideológico:
i) mediada pelas ideias, no estar e agir no mundo;
ii) no sentido partidário;
iii) como perspectivas e valores presentes nas obras;
iv) neutralidade, como parte de uma "leitura ideológica".

Sendo o sentido partidário o menos aceito historicamente, os avaliadores 6,8 e 13 revelam a complexidade da acusação feita, pois ideologia como visão de mundo incorpora-se à cultura e se alinha no mundo, como dito pelo avaliador 1. Brandão e Dias (2007) ao abordarem o pensamento de Gramsci nos ajudaram a delinear esta opção para o conceito de ideologia. Ao acusarem o conteúdo do LD de História no PNLD de incorrer em ideologização partidária de esquerda, Kamel (2007), estariam eles sim, os acusadores, impetrando uma visão de ideologia que colide a perspectiva gramsciana de ideologia como parte da cultura, como visão de mundo. Não necessariamente, uma tentativa de indução político-partidária como querem fazer Kamel. O LD, conforme legislação aplicada aos Editais, estaria a disponibilizar "visões de mundo".

Dos 13 avaliadores, seis entendem que há uma "eficiência" nos critérios de exclusão dos Editais no intuito de se evitar a presença, no conteúdo do LD de História, de Ideologia como propaganda:

Um dos itens dos Editais do PNLD faz referência à observância a propaganda ideológica salientando que é expressamente proibida. Desta forma é cada vez mais raro este tipo de ideologia, como propaganda religiosa, política partidária ou publicitária. Contudo, ideologia é maior que o âmbito da propaganda e sendo assim é difícil afirmar que não haja ideologias propagadas no livro didático de História, considerando que é um documento produzido por uma série de profissionais que fazem escolhas e estas não estão desvinculadas da forma como se pensa o mundo e seu entorno, o que se revela nas opções teóricas e metodológicas assumidas na elaboração da obra.

(Avaliador 2, 2015) Grifo nosso

O livro didático, como qualquer outra produção cultural, jamais será completamente isento de condicionantes ideológicos. Supor que seja possível eliminar a ideologia no processo de elaboração/aquisição/transmissão do conhecimento científico (ou dito científico) é algo que os filósofos e epistemólogos já descartaram há décadas. Nesse sentido, o livro didático é passível de ter, nele, incorporada a ideologia do seu autor, o que somente uma leitura atenta e contextualizada poderá revelar. Todavia, o que o livro não pode é realizar a apologia ou a detração de qualquer outra modalidade de pensamento, opção política, sexual ou religiosa. Ou seja, não podemos e nem devemos confundir o livro didático com um manifesto, panfleto ou programa político-partidário. Felizmente, parece-me que isso 
tem ocorrido cada vez menos na edição de cada PNLD, pois quanto a isso avaliadores têm prestado atenção redobrada.

(Avaliador 3, 2015) Grifo nosso

Tanto o Avaliador 2 quanto o 3 concordam que existem "tipos" de ideologias que devem ser rechaçadas - a política partidária e a publicitária. Tais falas revelam que essa é a preocupação central no ato de selecionarem as obras.

A fala a seguir, do avaliador 5, é explicita nesse sentido, e mais, questiona a mim, enquanto investigador, sobre o viés ideológico que nos move:

Afinal, qual o referencial teórico de quem pergunta? Isso é importante para eu saber o que essa pessoa entende por "ideologia". Se você identifica ideologia com proselitismo político partidário, ou como máscara do domínio de classe, a resposta é: não pode haver ideologia propagada nos livros didáticos. Não existe sujeito histórico neutro, e sendo o livro didático resultado da ação humana, ele também não pode ser neutro. Mas isso não significa que o livro deva se constituir como instrumento de propaganda política partidária. Proselitismo político é expressamente proibido pelos Editais, e há uma vigilância muito forte com relação a esse quesito, pois todos temos clareza da atenção conferida pela mídia e por grandes grupos econômicos a essa questão. As ideias defendidas nos livros didáticos devem estar, necessariamente, afinadas com o preâmbulo de nossa Constituição, que nos define como um "Estado Democrático, destinado a assegurar o exercício dos direitos sociais e individuais, a liberdade, a segurança, o bem-estar, o desenvolvimento, a igualdade e a justiça como valores supremos de uma sociedade fraterna, pluralista e sem preconceitos, fundada na harmonia social e comprometida, na ordem interna e internacional, com a solução pacífica das controvérsias". Trata-se não apenas de uma opção política, de uma visão de mundo, mas de uma política de Estado, que pauta todos os editais.

(Avaliador 5, 2015) Grifo nosso

Dois avaliadores salientaram que não há disseminação de ideologia nos LD aprovados:

Não. Ao menos as coleções que analisei estavam isentas deste aspecto. Em alguns casos chegamos realmente a identificar estereótipos em algumas coleções, fato que nos fez tomar decisões acerca da não aprovação.

(Avaliador 7, 2015)

Não há propaganda porque as obras são elaboradas com base em um edital que prescreve o que pode e o que não pode. Este é um quesito que poderá excluir a obra e, assim, tal questão deve ser pensada situando o livro didático como um produto da indústria cultural produzido por diferentes atores (editor, autor, ilustrador, diagramador) e comprado pelo governo brasileiro para ser utilizado em escolas públicas.

(Avaliador 10, 2015) 
Um panorama geral revela que os avaliadores lidam bem com a presença da ideologia como parte do processo, longe de uma ideia marxista de "falsa consciência", se aproximando mais da concepção gramsciana de ideologia e cultura.

A partir das respostas dos avaliadores pedagógicos sobre ideologia, nota-se a necessidade de diferenciação entre o conceito de ideologia em um sentido mais amplo, abordando visões de mundo (Brandão e Dias, 2007), na linha do pensamento gramsciano, uma concepção de mundo que se manifesta na ação e a organiza, em contrapartida ao conceito de ideologia política de esquerda, ou seja, o campo do proselitismo político ou propaganda, o que pela legislação e pelo próprio Edital é proibido de se ter no LD.

Nesse caso, o primeiro conceito aparece no conteúdo do LD, bem como na formação do autor de LD, e não haveria problema nisso. O segundo conceito de ideologia como propaganda ou proselitismo político de qualquer natureza, quando aparece no conteúdo dos LD, é excluído pela avaliação pedagógica por infringir os itens do Edital do PNLD, e não estar alinhado com a Constituição.

\section{A Questão 3: Os Editais do PNLD são suficientes para garantir os preceitos avaliativos estabelecidos pelo programa?}

Essa questão nos define como se orientam no ato da leitura e seleção: "não fechar a possibilidade sobre a natureza dos objetos a serem avaliados", pois "mais do que preceitos avaliativos sobre o que deve ser um livro didático, entendo que o edital define o que não deve ser ou conter numa obra didática, ainda que dê indicativos gerais a respeito do que se espera de um bom livro" (Avaliador 1, 2015).

Já o Avaliador 2 pondera mais um elemento que compõe o processo do PNLD:

O Edital, se respeitado e observado, pode garantir uma boa avaliação. Porém, não podemos desconsiderar o(s) olhar(es) do(s) avaliador(es), que por mais que se deseje imparcialidade é difícil conseguir tendo em vista a história de vida de cada um(a).

(Avaliador 2, 2015) Grifo nosso

Ou seja, mais uma vez a ideologia como visão de mundo, convicção, se apresenta. Mas, isso não impede, embora seja difícil, de fazer cumprir as orientações contra perspectiva política partidária e religiosa, com vistas à qualidade:

Sim, creio que esses preceitos avaliativos gerais são suficientes para garantir uma avaliação de qualidade. Além disso, em termos específicos 
há um detalhamento exaustivo de critérios, de maneira que dificilmente haverá algum aspecto do livro que deixe de ser observado, muito embora algumas coleções, pelo fato de se situarem numa zona mediana, sejam por vezes de difícil avaliação. Ou seja, não são ao mesmo tempo ótimas nem são ruins, caminhando para um meio termo que, no limite, não é o ideal, pois nessa posição ainda conseguem se manter no Guia.

(Avaliador 3, 2015) Grifo nosso

Da pouca experiência que tenho, acredito que sim. Os editais me aprecem bem amarrados aos princípios legais que norteiam a educação brasileira, aos princípios éticos, cidadãos e conceituais, além de valorizarem o professor por dedicarem parte de sua avaliação a este. Entretanto, acredito que deveria haver mais espaço para os aspectos gráficos e editoriais. Eles são extremamente importantes para obra e ainda estão reduzidos a itens que focam bastante nas imagens, que já possuem vários outros itens na análise que as contemplam.

(Avaliador 6, 2015)

O processo de avaliação é dinâmico não apenas na sua composição, pois há várias formas de se materializarem conceitos, e mais, obras e autores renovados podem ser aprovados em outro contexto. Trata-se, como é o campo da política, de negações, no caso, teóricas.

Creio que sim, bastando incluir que uma obra aprovada em uma PNLD pode não ser aprovada em outro, caso na nova avaliação sejam encontrados problemas que na avaliação anterior não foram encontrados ${ }^{24}$.

(Avaliador 11, 2015)

Um exemplo do peso desse olhar do avaliador sobre a obra é citado pelo Avaliador 4. Para ele, existe a necessidade de um edital mais específico, atentando para as questões dos movimentos sociais:

Alguns pontos, como o inciso III, IV, V e VI, sim, a forma como aparecem no Edital é fácil de ser observada, quanto aos incisos I, II penso que o edital deveria ser mais específico, pois se considerarmos que faz parte da legislação tratar o idoso, a criança, a mulher como sujeitos históricos, e se aparecem esporadicamente em uma obra deveria ser automaticamente excluída, mas isso não é possível, pois o fato de aparecerem nas obras já cumpre a legislação e é considerado contemplado na obra, essa discussão é ainda mais vivível quando se considera a questão da homoafetividade.

(Avaliador 4, 2015)

\footnotetext{
${ }^{24}$ Esta possibilidade é uma das marcas da diversidade avaliativa presente no PNLD. Existem vários exemplos de obras aprovadas em uma edição do PNLD e reprovada na edição subsequente. Exemplo da obra "Nova História Crítica", de Mario Schmidt, aprovada em 2005 e reprovada no PNLD 2008.
} 
Nesse contexto, observamos anteriormente que o Edital do PNLD 2008 atendia de forma mais contundente a esta necessidade interposta na resposta do Avaliador 4.

Já o Avaliador 6, ao mesmo tempo que afirma serem os critérios do Edital "bem amarrados" argumenta, porém, haver uma necessidade de "mais espaço para os aspectos gráficos e editoriais" em análise nos LD.

Em suma, essas respostas salientam a composição do olhar individual do avaliador sobre os preceitos do Edital do PNLD. A questão da subjetividade na interpretação e aplicação dos critérios avaliativos, os itens de exclusão, em particular, integram o processo.

Diante dessa constatação, merece destaque a opinião de alguns avaliadores em resposta à questão IV - De que forma o aprimoramento dos Editais do PNLD pode contribuir para a melhoria do programa?

Para o Avaliador 12 existe um contínuo aperfeiçoamento dos critérios avaliativos disponibilizados no Edital do PNLD:

De certo modo, os editais correspondem à vontade geral da sociedade brasileira no que se refere aos livros didáticos, resultando também do esforço de agregar um conjunto diverso de dispositivos legais existente. Os textos dos editais expressam sob qual perspectiva serão estabelecidos os contratos entre esta vontade da sociedade e o papel criativo de autores e equipe técnica responsável pela elaboração dos livros didáticos, com apoio de um grupo editorial, com capacidade instalada para a produção de grandes quantidades de livros didáticos. Deste modo, parece evidente que o aprimoramento dos editais do PNLD pode contribuir para a melhoria do próprio Programa, no sentido de dar maior precisão e direcionamento para a ação dos contratantes.

(Avaliador 12, 2015) Grifo nosso

A resposta do Avaliador 7 evidencia a necessidade de aprimoramento nos critérios dos Editais do PNLD no sentido de propiciar temas importantes dos componentes curriculares voltados para a Educação em direitos humanos:

Eles devem atentar para o próprio movimento e dinâmica social, as alterações e anseios da sociedade. Atualmente, entre tantas as demandas e propósitos que procura atender, acho salutar que seja desencadeada uma boa discussão acerca da educação em e para os direitos humanos.

(Avaliador 7, 2015) Grifo nosso

No decorrer das questões, as dificuldades nas escolhas das obras se mostraram presentes na fala de alguns avaliadores, quando trazem à tona uma característica que permeia algumas 
avaliações pedagógicas de LD e revelam que algumas obras, mesmo sendo selecionadas para compor o Guia do Livro Didático do PNLD, não possuem, por exemplo, um parecer e uma resenha tidos como muito bons. Essas obras não descumprem os requisitos avaliativos dos Editais do PNLD, porém não atingem o esperado no que se refere à qualidade de conteúdo necessária do ponto de vista do avaliador.

A referência à fragilidade da abordagem em relação às exigências típicas da área de História:

A realidade muda, o conhecimento muda, o olhar dos avaliadores e as estratégias editoriais também mudam, de maneira que devemos estar sempre atentos para incorporar, nos editais futuros, novos critérios que permitam o aprimoramento da avaliação. Eu, particularmente, penso que uma coleção mediana, que se manteve apenas pelo fato de não cometer equívocos sérios, mas que não inova ou não contribui decisivamente para o aprendizado da disciplina, somente poderia ser reinscrita no PNLD se passasse por uma revisão criteriosa dos pontos falhos assinalados pelos avaliadores. Isso porque acredito que temos condições de oferecer ao aluno um livro de excelente qualidade. Ou seja, os alunos não são obrigados a consultar um livro mediano quanto poderiam consultar um livro bom ou muito bom.

(Avaliador 3, 2015) Grifo nosso

Também é similar a percepção trazida pelo Avaliador 1:

O aprimoramento dos Editais pode deixar mais claro o que se espera de uma obra didática que seja boa, contributiva e efetiva como instrumento auxiliar no processo de ensino-aprendizagem, em detrimento de uma obra que "apenas" não descumpre o edital.

(Avaliador 1, 2015)

Tanto o Avaliador 3 quanto o 1 revelam que as obras aprovadas e que compõem o Guia do LD não são necessariamente obras "boas", e que deixam a desejar, mas como cumprem minimamente o Edital, permanecem no Guia.

Nesses casos, ficam algumas indagações: seria realmente uma falha nos itens do Edital do PNLD? Ou poderia ser uma maior rigidez na avaliação feita por alguns avaliadores, talvez por maior domínio desse ou daquele conteúdo?

Nota-se que a complexidade do campo do ensino de História se apresenta no ato da avaliação e tenciona o entendimento dos professores avaliadores. 
O Avaliador 5 atenta, por exemplo, para as limitações de um ensino compartimentado em disciplinas e na própria limitação de uma tradição escolar que, segundo ele, não valoriza os conhecimentos prévios do aluno:

Embora haja um consenso sobre os prejuízos de um ensino compartimentado, conteudista, que ignore a realidade e conhecimentos prévios dos alunos, incapaz de contribuir para o desenvolvimento de sujeitos autônomos, críticos e criativos, essa mudança não pode ser operada num prazo curto. Afinal, estamos lidando com uma tradição escolar que remonta à primeira metade do século XIX. As mudanças no edital forçam autores e editoras a rever suas perspectivas no sentido de entender, de forma cada vez mais clara, que mais e novos conteúdos não bastam para se realizar a mudança desejada.

(Avaliador 5, 2015)

Há de se saber se essa reflexão não está alinhada à sensação de incapacidade de mudar uma realidade que extrapola o Livro Didático, uma influência com um formato compartimentado e conteudista.

Já os Avaliadores 11, 9 e 8 sugeriram as seguintes mudanças nos Editais do PNLD:

Incluindo-se salvaguardas para que as obras uma vez aprovadas, quando reavaliadas sejam passíveis de exclusão.

(Avaliador 11, 2015)

Acredito que deveria haver uma nota explicativa no final do edital para esclarecer os pontos mais polêmicos da proposta.

(Avaliador 9, 2015)

Poderiam centrar mais nas especificidades de cada área, nem sempre os critérios parecem adequados para a nossa disciplina - História

(Avaliador 8, 2015)

Em resumo, nota-se que a questão IV abriu espaço para revelar o desconforto dos avaliadores em relação às obras que estão aprovando. Provavelmente, por falta de algo mais adequado à dinâmica social.

A sugestão do Avaliador 11 já é uma realidade no processo do PNLD. A nota explicativa para esclarecer os pontos mais polêmicos de um LD avaliado talvez seja abarcada pelo próprio parecer de avaliação do LD, bem como na resenha da obra apresentada no Guia, caso aprovada. Nesses documentos, aparecem ressalvas e recomendações de uso para que se minimizem alguns problemas apresentados pela obra. 
A maior parte das respostas obtidas direciona para a necessidade contínua de aperfeiçoamento dos critérios avaliativos dos Editais do PNLD, em particular no que tange às obras "medianas" que cumprem os critérios de forma mínima ou formal, mas não atingem a qualidade esperada.

A qualidade está estipulada nos próprios itens do Edital do PNLD e na legislação balizadora do programa, mas que, na prática, tem que ser aplicada em obras que evidenciam a fragilidade dos autores em atender aos princípios basilares do campo do ensino de História. Daí, a importância de pensarmos: ser graduado em História deveria ser uma exigência para autores de LD de História? Passemos à leitura da questão V.

\section{Você acha que a formação acadêmica na área de História para o autor de LD participante do PNLD deveria ser uma exigência? Poderia auxiliar na melhoraria de obras inscritas no processo de avaliação?}

A quinta questão do questionário tinha como objetivo obter uma análise da pertinência ou não de se instituir a obrigatoriedade da formação acadêmica específica do autor de LD participante do PNLD; essa questão já fora tema em debate dentro do processo do PNLD no âmbito do MEC e das IES. Trata-se de conhecer também o perfil do autor de Livro Didático que inscreve sua obra no âmbito do PNLD.

Nesse intuito, além da questão $\mathrm{V}$ do questionário aplicado junto aos avaliadores, fizemos um breve levantamento acerca da formação acadêmica dos autores de LD com obras aprovadas no Guia do Livro Didático de História do PNLD 2014.

Os dados coletados estão no Quadro de dados sobre os autores de LD aprovados no PNLD 2014 (anexo). Nele, estão presentes o nome da obra didática, ano e edição, editora responsável e os autores com sua respectiva formação acadêmica. A partir desse conjunto, constatamos que dos 41 autores pesquisados, a maioria, cerca de 70,73\%, possui a formação/ graduação em História. Destes, 63,41 apresentam diplomas de instituições de ensino superior sediadas no Estado de São Paulo. A geografia das instituições de ensino superior dos autores de LD, neste contexto, prevalece na Região Sudeste do País.

Na busca de traçar um perfil mínimo do autor de LD de História, ou pelo menos, procurar apurar uma percepção de qual deveria ser esse perfil, na visão dos avaliadores envolvidos no processo, a referida questão $\mathrm{V}$ foi aplicada. 
Nas respostas dos Avaliadores 1, 3, 5 e 8, percebemos a recomendação de que a formação na área de História se expressa como uma garantia a mais na busca de qualidade na elaboração do LD de História:

Entendo que a formação na área deve ser uma premissa básica a submissão de obras didáticas, posto que tais profissionais têm formação específica e devem dar conta da produção e estratégias de socialização do conhecimento sem seus campos de atuação. Entendo, todavia, que uma proposta que interaja com outros campos - e profissionais - do saber, tende a fortalecer a perspectiva interdisciplinar, mesmo que ela não deva, contudo, perder seu caráter como área específica do saber.

(Avaliador 1, 2015) Grifo nosso

Quanto a isso, não tenho a menor dúvida, pois, como já assinalei, a avaliação possui um aspecto conteudista, informativo. Somente um profissional que tenha domínio acerca dos conteúdos e procedimentos da disciplina poderá assinalar os eventuais equívocos. Seja na condição de graduado, mestre ou doutor em História, a formação na área é importante para o êxito da avaliação.

(Avaliador 3, 2015) Grifo nosso

Sim, pois um dos principais problemas das obras didáticas é a falta de referenciais teóricos, ou incoerência entre os referenciais explicitados no manual do professor e o conjunto de textos e atividades propostos no livro do aluno. Portanto, a formação na área, assim como o diálogo com outros especialistas formados em suas respectivas áreas, contribuiria para uma melhor qualificação desse material.

(Avaliador 5, 2015)

Sempre deve ser uma exigência. Basta de outros se arvorarem no direito de definir o que deve ou não ser ensinado em história é preciso que historiadores façam o seu trabalho.

(Avaliador 8, 2015)

Sim, pois aquele que tem formação acadêmica em história tem base (Historiografia, teoria da História etc.), para melhor analisar as obras do PNLD.

(Avaliador 9, 2015)

Sem dúvida, a formação em história é óbvia e fundamental. Penso que deveria ser critério. Nenhum outro profissional poderá dar conta dos conceitos do campo, senão aqueles indivíduos do próprio campo.

(Avaliador 13, 2015)

O Avaliador 7 concorda com a proposição de que o autor de LD de História com formação na área de História produz uma obra com garantia de qualidade, mas pondera que, para além da formação, o autor licenciado em História deve estar atento à questão do ensino em História, que se conecta ao campo mais amplo da educação: 
Sim. O professor licenciado em história é o profissional que tem as melhores credenciais para escrever livros de história. Repito, o licenciado - que passa por uma formação tanto da área específica como da área de formação de professor incluindo aí toda a discussão da didática, da pedagogia e da educação.

(Avaliador 7, 2015) Grifo nosso

Também o Avaliador 10 alerta para a importância do ensino em História:

Sem dúvida que o autor de livro didático deveria comprovar formação acadêmica que envolvesse conhecimentos de História e de Educação já que estamos falando de material pedagógico para as escolas. Conhecer o ofício do historiador e os conteúdos de História e Educação significa estar mais preparado para escrever um material que define, em parte, como a história será ensinada ou como os conteúdos serão abordados nas escolas.

(Avaliador 10, 2015) Grifo nosso

Coletamos uma visão diferente dos avaliadores anteriores a partir da resposta do Avaliador 6, para quem este não haveria necessidade de tal exigência e que problematiza essa questão, analisando-a como sectária e ingênua:

Considero essa possibilidade sectária e ingênua. Sectária no sentido de circunscrever o uso da história à "corporação" que, historicamente sempre viu na escrita didática uma narrativa de $2^{\mathrm{a}}$ mão e ingenuidade por acreditar que a passagem pelas disciplinas do curso superior ou sua formação específica em história produza alguém mais capacitado do que outros escritores com formações diversas para o trabalho com a escrita didática da história.

(Avaliador 6, 2015) Grifo nosso

A opinião do Avaliador 6 contrasta com grande parte da visão dos outros avaliadores participantes deste questionário. Para a maioria, a formação na área de História seria uma garantia a mais de qualidade na produção do LD, como sendo a formação específica na área de História a "garantia" mínima para a qualidade do LD.

Segundo o Avaliador 11:

A noção de autoria no LD é complexa, pois inclui uma série de agentes. $\mathbf{O}$ que deve ser aferida é a qualidade do material apresentado segundo regras claras de avaliação, da escolha de um corpo de avaliadores e de uma comissão de avaliação qualificados para o processo.

(Avaliador 11, 2015) Grifo nosso

Nesse sentido, ao problematizar a questão da qualidade no LD de História, vimos que muitos aspectos ultrapassam os itens estipulados nos Editais do PNLD. Esses itens são balizados por um conjunto de Leis que atentam para aquilo que se entende como necessário 
para a formação de um cidadão na sociedade brasileira atual e perpassa, também, pela formação dos autores de LD de História.

Nota-se que a maior parte das respostas foram favoráveis à exigência de diplomação/formação acadêmica na área específica da disciplina a qual o autor produz o LD. Parece um indicativo a ser levado em conta em discussões de aprimoramento do Edital do PNLD a formação do autor na área específica do componente curricular em que a obra está inscrita como uma garantia a mais na qualidade do LD de História apresentado para a avaliação no âmbito do PNLD.

\section{Questão VI (Qual seu nível de satisfação com os instrumentos oferecidos para o processo de avaliação e seleção dos LD no âmbito do PNLD?)}

A sexta questão visava obter feedback dos instrumentos disponibilizados para a avaliação pedagógica dos Livros Didáticos participantes do PNLD, como o Edital, o Decreto do Livro Didático e as resoluções do MEC, FNDE e CNE.

Nesse sentido, 8 avaliadores $(1,2,5,7,8,9,11,12)$ responderam com satisfatoriedade, apontando não haver necessidade de mudança na legislação aplicada ao processo avaliativo do PNLD, nem nos próprios critérios do Edital. Nesse contexto, destacamos a fala dos Avaliadores 2 e 12:

Como convidada para ser avaliadora do PNLD desde 2005, percebo que a cada edição este Programa se aprimora e se torna mais transparente para a sociedade. Diante do exposto me sinto contemplada com os instrumentos oferecidos que são de domínio público, que dão subsídios suficientes para qualificar a avaliação.

(Avaliador 2, 2015) Grifo nosso

Penso que a vontade da sociedade brasileira na atualidade esteja suficientemente contemplada nos dispositivos legais existentes, que ao serem complementados por instrumentos de avaliação particulares, tais como as fichas de avaliação específicas das diferentes áreas do PNLD, asseguram à aquisição e distribuição pelo Estado brasileiro de livros didáticos comprometidos com a formação de um cidadão republicano, com espírito democrático, tolerante e participativo da vida social nacional.

(Avaliador 12, 2015) Grifo nosso

Porém, 5 avaliadores $(3,4,6,10,13)$ responderam ser necessários ajustes ou aprimoramento nos itens dos Editais do PNLD, bem como aprimoramento na ficha de avaliação utilizada por eles. Nesse sentido, alertam para a necessidade de mais exatidão e menos 
redundância dos critérios avaliativos e principalmente na ficha de avaliação apresentada pelas IES aos avaliadores durante a avaliação pedagógica.

Essas considerações são exemplificadas nas falas dos avaliadores 6 e 10:

Em grande parte, satisfeito, mas, partindo do princípio de que nesse "etc." da pergunta cabem outros materiais, meu único comentário é sobre a ficha de avaliação que nos é disponibilizada. Acredito que poderia ser mais enxuta e em alguns itens menos vaga, genérica. Alguns itens são bastante parecidos, o que gera uma certa circularidade na avaliação. Acabamos por nos repetir bastante nos exemplos. Acho que isso compromete a qualidade da avaliação.

(Avaliador 6, 2015)

De forma geral os Editais se constituem em parâmetros razoáveis para sustentar uma avaliação coerente com a legislação e os pressupostos teóricos e metodológicos para o ensino de História. Talvez pudesse incluir de forma mais incisiva critérios que indicassem a incorporação de novas abordagens em relação aos conteúdos, considerando que ainda predominam temas tradicionais do currículo com abordagens políticas e econômicas.

(Avaliador 10, 2015) Grifo nosso

A questão VII tratou do prazo disponibilizado pelo MEC, perguntou-se aos avaliadores se esse prazo seria suficiente para um processo de avaliação e seleção de LD com qualidade. A complexidade da avaliação ${ }^{25}$ no processo do PNLD tem sido foco de constantes pedidos de ajustes por parte das instituições de ensino superior. A fala do Avaliador 1, corroborada pela do Avaliador 10, mostra que os avaliadores não estão satisfeitos com as obras que aprovam.

O Avaliador 1 relata que:

Não, a luta para cumprir prazos sempre exíguos e entregar uma avaliação que se sustente é um dos grandes desafios enfrentados pelo avaliador. Cabe reiterar que não se trata de ler, reler, avaliar e dar conta do preenchimento dos instrumentos de avaliação que são dispostos. O avaliador precisa ler e dominar também uma ampla legislação que trata da questão, conforme explicitado no próprio edital e curto tempo dispensado a avaliação é sem dúvida uma das questões mais difíceis de enfrentar no processo.

(Avaliador 1, 2015) Grifo nosso

O avaliador 3 reforça a necessidade de disponibilização de mais tempo para a realização deste trabalho:

Infelizmente, não. A impressão que tenho é que a cada edição do PNLD trabalhamos com um cronograma mais apertado, o que não é bom. Creio

\footnotetext{
${ }^{25}$ Por tradição e estudos internos realizados na SEB, o prazo médio disponibilizado para a avaliação pedagógica no âmbito das IES foi de 120 dias, nos últimos PNLD (2016, 2015 e 2014) este prazo chegou a ser de 90 dias.
} 
ser necessário rever o mais rápido possível o andamento do processo, pois, como diz o provérbio, "a pressa é inimiga da perfeição". Muitas vezes nos familiarizamos de fato com a obra quando já estamos finalizando a avaliação, pois não tivemos tempo suficiente para amadurecer nosso olhar sobre o livro. Não que isso comprometa o trabalho de modo irremediável, pois um livro ruim dificilmente será recomendado. Todavia, penso na avaliação dos que são recomendados, pois com um pouco mais de tempo é sempre possível produzirse uma resenha de melhor qualidade, que traduza os pontos forte da coleção.

(Avaliador 3, 2015) Grifo nosso

Por fim, as falas também importantes advieram dos avaliadores 5 e 12 que observam uma das causas possíveis para o pouco tempo disponibilizado para a avaliação pedagógica:

A demora na descentralização dos recursos, que torna o processo viável, prejudica o trabalho de todos. Os avaliadores não interrompem suas atividades para participar no PNLD, até porque essa participação é sigilosa. Portanto, a avaliação dos livros didáticos deve ser conciliada com nossas múltiplas tarefas. Trata-se de um trabalho minucioso, da mais alta responsabilidade e sempre flui melhor quando dispomos do tempo necessário.

(Avaliador 5, 2015) Grifo nosso

Em tese os prazos seriam suficientes, mas, por vezes, os atrasos nos cronogramas, motivados, quase sempre, por razões de natureza orçamentária ou burocrática, prejudicam o andamento das atividades, o que, em muitas oportunidades, é compensado por um esforço dos agentes envolvidos, na avaliação, na impressão dos guias, na seleção pelos professores e na distribuição nas escolas.

(Avaliador 12, 2015) Grifo nosso

A descentralização a que se refere o Avaliador 5 diz respeito ao processo interno MECFNDE-IES para o repasse de recursos financeiros destinados a subsidiar o processo de avaliação no âmbito do PNLD. Ocorre que nos últimos anos, por problemas internos afetos ao MEC e também às IES, ocorreram diversos atrasos nesses procedimentos de descentralização de recursos.

Somente os avaliadores 3,7 e 13 concordaram ser suficiente o tempo disponibilizado para a realização da avaliação pedagógica no PNLD.

Em resumo, a maioria dos avaliadores salienta que os prazos para a avaliação pedagógica dos LD inscritos no programa estão muito curtos, que os atrasos decorridos nos processos do PNLD e do próprio cronograma estabelecido atrapalham a execução da avaliação pedagógica. Isso porque há um tempo para leitura e amadurecimento da análise.

Nesse contexto, também, caberia indagar se suas próprias atividades nas IES prejudicariam a entrega da avaliação pedagógica. Quase todos os avaliadores exercem 
atividades acadêmicas em suas respectivas universidades, bem como os avaliadores oriundos dos outros níveis de ensino.

O tempo é considerado exíguo para a complexidade, responsabilidade e tamanho dos trabalhos, desde a leitura das coleções didáticas, preenchimento da ficha de avaliação disponibilizada e elaboração dos pareceres avaliativos. Essa sobrecarga é um ponto importante a ser considerado.

A oitava e última pergunta aplicada aos avaliadores pedagógicos do PNLD, "Descreva livremente sugestões para aprimoramento dos instrumentos avaliativos do Edital do PNLD”, teve o objetivo de captar a percepção desses no sentido do que pode ser melhorado no processo avaliativo. As sugestões foram apresentadas visando o aprimoramento dos instrumentos do Edital do programa, que sistematizam grande parte do que já foi apresentado.

Diante do quadro traçado e da análise de todas as etapas contidas nos Editais do PNLD, os documentos de 2008, 2011 e 2014, destacamos uma das sugestões feitas pelo Avaliador 5:

\begin{abstract}
A inserção de uma nova etapa no processo, que se responsabilize por uma pré-avaliação pedagógica. Exemplo disso: ainda há editoras que inscrevem livros sem bibliografia, número excessivo de páginas e com imagens de armas e bebidas, situações expressamente proibidas e que podem ser detectadas muito prontamente. Livros com esse tipo de problema não precisariam passar por uma avaliação minuciosa para serem excluídos.
\end{abstract}

(Avaliador 5, 2015) Grifo nosso

Esse alerta, "sugestão de se instituir uma nova etapa de pré-avaliação pedagógica", corrobora com as denúncias da existência de obras "medianas", mas mais do que isso, equivocadas, e menos com questões partidárias, e mais com uma convivência pacífica e respeitosa, como por exemplo, determinam as Leis 10.639/2003 e 11.645/2008 e outras já citadas. Entretanto, parece que o rol de determinadas leis ainda não é do conhecimento e domínio de autores e editores.

Assim, essa "nova etapa no processo", na prática, já existe. A mesma está prevista como pré-análise dos LD realizada antes da avaliação pedagógica, conforme estipulado no item 6.2.1. “Da Pré-analise”, no Edital do PNLD 2008 (BRASIL, 2005), no item 6.2.1. "Da pré-análise", no Edital do PNLD 2011 (BRASIL, 2008), bem como no item 7.3. "Da Pré-análise" no Edital do PNLD 2014 (BRASIL, 2011). Em todos os Editais, esses itens possuem o caráter eliminatório. Ou seja, a obra pode não ser habilitada para a avaliação pedagógica.

Porém, quando o avaliador salienta que a pré-análise dos LD precisa ser mais criteriosa, é evidente que a Secretaria de Educação deva analisar, reavaliar e aprimorar esse procedimento 
na elaboração dos futuros editais do programa. Porque, como dito, muitos LD com erros estão passando. A SEB deve atentar para a necessidade de uma maior eficiência e competência na elaboração dos instrumentos avaliativos e maior foco nos direitos humanos.

Outra sugestão, a de eliminar as falhas pontuais ${ }^{26}$ da avaliação pedagógica, feita pelo Avaliador 8, é complexa e pode ser temerária para a SEB, pois esse dispositivo consta do Decreto $n^{\circ} 7.084 / 2010$, ou seja, já existe precedente jurídico nas avaliações do programa nos anos de 2015 e 2016, onde tal item foi aplicado. Retroagir nesse procedimento, além da necessidade de um novo decreto, demandaria um debate maior junto aos atores do PNLD, sejam eles autores e editoras, as equipes das universidades participantes e da própria política do MEC para com o PNLD.

Os avaliadores indicam, também, como sugestões para melhoria do processo de avaliação, um Edital mais específico e com maior tempo para a avaliação pedagógica do LD, um Edital com melhor redação e revisão para evitar as redundâncias que ocorrem e que atrapalham o processo de análise das obras.

As sugestões indicadas apresentam-se como pertinentes para a melhoria do Edital e do programa. Caberá à SEB analisar a viabilidade de cada uma delas dentro dos processos do PNLD.

\footnotetext{
${ }^{26}$ Este dispositivo legal instituído pelo Decreto $n^{\circ} 7.084 / 2010$ estabelece que as obras aprovadas na avaliação pedagógico do PNLD podem ser indicadas à correção de falhas pontuais. Nesse sentido, a obra que estiver nessa condição terá um prazo de 15 dias para que a Editora/Autor corrija o indicado no parecer disponibilizado. Se cumprida as indicações de correções, a obra fica habilitada a compor o Guia do Livro Didático; se não cumpridas as correções, a obra tem sua avaliação revertida para exclusão no PNLD em que ela foi avaliada. Esse procedimento foi aplicado a partir do PNLD 2014.
} 


\section{CONCLUSÃO COM RECOMENDAÇÃO: PERSPECTIVAS PARA O PNLD}

Ao concluir este estudo, com base nos dados, propomos melhorias nos mecanismos de elaboração dos editais do PNLD, no sentido de aprimorar a avaliação pedagógica dos Livros Didáticos participantes do programa.

O foco evidenciado a partir da leitura, análise e interpretação da legislação aplicada ao contexto do PNLD e especificamente dos Editais trabalhados neste estudo, os documentos de 2008, 2011 e 2014, atenta para o objetivo de formar o educando com senso crítico e autônomo para exercer seu papel de cidadão, uma formação para a cidadania, conforme expresso na Constituição Federal de 1988, reiterado na LDB de 1996 e como princípio que baliza os editais do PNLD aqui analisados. A busca por uma educação emancipatória do indivíduo é possível a partir da formação crítica e autônoma do educando? A partir dessa formação, o cidadão estaria apto ao exercício de seus direitos e deveres na sociedade brasileira? Pensamos que sim.

Concluímos, na análise feita, que o PNLD entende qualidade na perspectiva da educação não como mercadoria, balizada pelos valores mercadológicos, mas como direito que deve ser para todos e que objetive a emancipação, minimamente crítica, do indivíduo.

Como sugestões, observamos a necessidade de se retomarem critérios e princípios do Edital do PNLD 2008 suprimidos nos de 2011 e 2014. Retomar e aprofundar o princípio que visa garantir e estimular a autonomia na prática pedagógica do professor em sala de aula, como forma de garantir e estimular os princípios da diversidade, liberdade, respeito e compreensão da realidade que o material didático deve ter em seu conteúdo e metodologias apresentadas. Nesse sentido, reforçamos o entendimento de que a prática pedagógica não é um caminho único, ela é plural.

Diante dos relatos e denúncias feitas pelos avaliadores, salientamos a necessidade de se reforçarem os itens avaliativos nos próximos editais do PNLD referentes à qualidade pedagógica das obras a serem selecionadas. Qualidade definida e defendida na linha de pensamento de Pedro Demo (1994) com ênfase no "sentido humano" e dentro de "valores e fins historicamente considerados desejáveis e necessários, eticamente sustentáveis” (p. 12, 1994). Uma qualidade alicerçada em um sentido progressista de valorização do sujeito no exercício da cidadania, democrática e progressista, conforme Gentili (2007).

Reforçamos o item do edital que estabelece que os LD não podem veicular preconceitos de condição econômico-social, étnico-racial, gênero, linguagem e qualquer outra forma de discriminação, conforme definido pela legislação usual do campo da educação em vigor. 
O PNLD deve continuar a evitar habilitar um LD que faça doutrinação de qualquer tipo, desrespeitando o caráter laico e democrático do ensino público, mas sem, ao mesmo tempo, censurar conteúdos históricos e necessários para compreender a contemporaneidade da sociedade. Por exemplo, a ação política dos personagens na história, individuais e coletivos, movimentos sociais e movimentos sindicais.

Para isso, observamos a necessidade de reforçar a preocupação e a necessidade de buscar um LD mais próximo das demandas sociais, tais como a questão do papel e do lugar do negro na sociedade brasileira, bem como da mulher. Também deveras importante, o papel e o lugar do indígena nessa mesma sociedade, que adjetivamos deva ser plural. Assim, os critérios avaliativos que convergem para essas temáticas devem ser mais bem detalhados, ou como salientaram os avaliadores, mais direcionados para a diversidade e para os direitos humanos.

No edital de 2008, fica exposto que o ensino de História deve proporcionar aos estudantes a formação básica necessária para o exercício da cidadania, formar o indivíduo consciente de seu papel na sociedade. Um material didático habilitado pelo PNLD apto a propiciar ao aluno a compreensão da trama social que caracteriza a sociedade em que o mesmo vive. Esse entendimento e princípio devem voltar aos futuros editais do PNLD.

Observamos que o princípio e os objetivos para o ensino de História contidos no Edital de 2008 perderam-se nos outros dois editais estudados, no de 2011 e 2014. Objetivos esses alinhados às demandas da contemporaneidade, emanados da sociedade civil organizada e pelos movimentos sociais, muitas deles estipulados em leis, como a Lei 10.639/2003. Mais do que listar, é preciso detalhar, recuperar o princípio de luta antirracista e antissexista.

Consideramos pertinente para os próximos editais a serem elaborados pela SEB/MEC o aperfeiçoamento dos critérios específicos da área de História. No documento de 2008, foram apresentados como critérios de exclusão que o LD deveria cumprir: i) correção dos conceitos e das informações básicas não podendo o LD incorrer em anacronismo, voluntarismo e nominalismo; ii) o LD não pode conter erros de informação ou informações desatualizadas; iii) o LD não pode ferir os preceitos éticos, não pode incorrer em nenhum tipo de preconceito.

A volta do uso do conceito de nominalismo poderia ser um reforço para os critérios de exclusão das obras de História. Um reforço que dá visibilidade "às relações sociais, dos agentes históricos, que efetivamente são os autores de História" (Berrutti e Marques, 2009, p. 102) em contraponto à atribuição de "vida e vontade" às instituições ou categorias de análise.

As sugestões colhidas a partir das respostas ao questionário aplicado junto aos avaliadores pedagógicos do PNLD podem ser objeto de estudo e posterior implementação pela SEB/MEC. Evitar a duplicidade na ficha de avaliação e aprimorar esse documento 
desenvolvido pelas universidades responsáveis pela avaliação pedagógica são estratégias que podem contribuir com a qualidade da avaliação desenvolvida pelo PNLD.

A necessidade de maior prazo para desenvolver a avaliação pedagógica é pertinente e desejável. Para isso, sugerimos que no tópico sobre a avaliação pedagógica seja estipulado um prazo fixo para a realização da avaliação, sendo os 120 dias usuais insuficientes, conforme relato dos avaliadores. Um avanço significativo seria estipular o prazo de para 150 dias. Essa ampliação do prazo e sua validação no próprio Edital, o que não é feito, obrigaria os responsáveis pelo PNLD a cumprir tal item no Edital, além é claro, de atender à demanda explicitada pelos avaliadores em suas recomendações.

A sugestão de maior eficiência e competência na elaboração dos instrumentos avaliativos e maior foco nos direitos humanos é uma demanda cada vez maior no contexto do PNLD. Acrescentar critérios avaliativos nesse sentido é uma demanda apropriada, principalmente nas componentes curriculares da área de Humanas. A crítica feita a respeito de uma melhor redação/revisão do Edital para evitar as redundâncias é outra demanda para que a SEB/MEC organize melhor a elaboração do Edital do PNLD, tendo um cuidado redobrado na confecção desse instrumento.

Outra sugestão relevante feita pelos avaliadores pedagógicos do programa foi a de melhorar os instrumentos para o quesito interdisciplinar. Nessa direção, um aprofundamento teórico e metodológico nas Diretrizes Curriculares Nacionais Gerais da Educação Básica deve ser considerado e levado a sério, ou seja, sua implementação de forma mais aprofundada nos itens avaliativos é uma recomendação.

A observância feita a respeito do Guia do LD, que esse deveria chegar com tempo adequado e hábil às escolas para a escolha dos LD é um problema sério que o MEC precisa resolver, no sentido de disponibilizar mais tempo para que os professores possam fazer uma escolha adequada e bem fundamentada. Nas últimas edições do PNLD, esse prazo variou de 15 a 20 dias, o que evidentemente não é adequado. Indicamos a necessidade de se estabelecer um prazo maior, ao menos 30 dias para que os professores possam ter contato com o Guia e, a partir de seu uso, qualificar a escolha do livro a ser utilizado pela escola.

Outra sugestão pertinente elencada a partir das respostas obtidas pelo questionário aplicado junto aos avaliadores pedagógicos é a de rever a composição das resenhas, que deveriam ser mais objetivas. Essa sugestão pode ser estudada no âmbito da SEB/MEC com as equipes envolvidas nos processos de avaliação do PNLD, equipe técnica da Coordenação-Geral de Materiais Didáticos/Cogeam e Comissão Técnica do PNLD, bem como, rediscutida no âmbito da equipe de avaliação constituída pelas IES. Tornar a resenha um instrumento mais 
objetivo, com menos detalhamentos e redundâncias pode ser a chave para seu efetivo aprimoramento.

Por fim, concluímos que os Editais do PNLD 2008, 2011 e 2014 juntamente com o questionário aplicado aos avaliadores pedagógicos do PNLD revelam um rol de necessidades e sugestões para a melhoria e o aprimoramento do processo de avaliação e seleção das obras didáticas inscritas no PNLD.

A importância e a qualidade do Livro Didático ofertado no âmbito desse programa podem e devem ser aperfeiçoadas, refinadas e atualizadas. Entendemos ser esse o ponto de partida para que a SEB/MEC aperfeiçoe o desenvolvimento dessa política educacional que diz respeito e evidencia os interesses da comunidade escolar do país. 


\section{ANEXO I}

A seguir, o modelo de questionário aplicado aos avaliadores participantes das avaliações pedagógicas das etapas do PNLD relativas aos anos 2008, 2011 e 2014:

Tema da Pesquisa: Qualidade e/ou Ideologia: Conexões PNLD e Livro Didático de História.

Este estudo atende à exigência parcial para obtenção do título de mestre do Programa de Pós-Graduação em Educação (UnB), Mestrado Profissional, Área de Gestão de Políticas e Sistemas Educacionais, sob a orientação da Profa. Dra. Renísia Cristina Garcia Filice. Tem como objeto o Programa Nacional do Livro Didático (PNLD) e, como objetivo geral, analisar qual o conceito de qualidade permeia a legislação e como ele se materializa nos Editais (2008, 2011, 2014) e na concepção dos avaliadores. O intuito é responder à seguinte questão: Em que medida os livros didáticos de História selecionados e ofertados pelo MEC às escolas públicas do país atende ao conceito de qualidade contido nos Editais?

Trata-se de uma pesquisa qualitativa e optamos por fazer uso da aplicação de questionários e entrevistas.

Por sua importante participação na avaliação das obras inscritas no PNLD, viemos, respeitosamente, solicitar suas respostas ao nosso questionário.

Considerando as normas estabelecidas, CASO O/A DECLARANTE NÃO AUTORIZE A REFERÊNCIA À SUA INSTITUIÇÃO DE ORIGEM, POR GENTILEZA, BASTA MARCAR NO ESPAÇO DEFINIDO A SEGUIR.

\section{Antecipamos agradecimentos e solicitamos que RETORNE NESTE MESMO}

EMAIL até o dia 25 de abril de 2015.

Nome (opcional):

Instituição:

de contato:

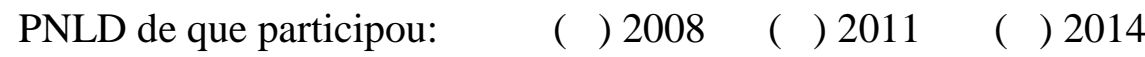

Aceito a utilização dos dados mencionados em relação ao PNLD ( )

$\underline{\text { Solicito sigilo em relação à minha instituição de origem ( ) }}$

Qualquer dúvida contatar pelo e-mail kaiseralbernaz@gmail.com, e telefones: (61)

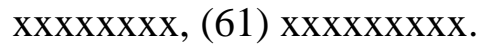

Muitíssimo obrigado!

Ricardo 
1. Questionário aplicado

Questão I - À luz dos conhecimentos acadêmicos na área de História, como você interpreta o conceito de Qualidade do Livro Didático exposto no Edital do Programa Nacional do Livro Didático (PNLD)?

(Informe o Edital do PNLD a que se refere: ( ) 2008 （ ）2011 （）2014))

Questão II - Você acredita que haja ideologias propagadas no Livro Didático de História participante do PNLD? Em caso positivo, justifique.

(Informe o Edital do PNLD a que se refere: ( 2008 ( ) 2011 ( ) 2014))

Questão III - Os Editais do PNLD são suficientes para garantir os preceitos avaliativos estabelecidos pelo programa? A saber:

Art. $19^{\circ} \mathrm{A}$ avaliação pedagógica dos livros didáticos no âmbito do PNLD será realizada com base em critérios comuns e critérios específicos para os diversos componentes curriculares, considerando-se, necessariamente, sem prejuízo de outros:

I - o respeito à legislação, às diretrizes e normas gerais da educação;

II - a observância de princípios éticos necessários à construção da cidadania e ao convívio social republicano;

III - a coerência e adequação da abordagem teórico-metodológica;

IV - a correção e atualização de conceitos, informações e procedimentos; $\mathrm{V}$ - a adequação e a pertinência das orientações prestadas ao professor; $\mathrm{e}$ VI - a adequação da estrutura editorial e do projeto gráfico.

(BRASIL, Presidência da República. Casa Civil. Decreto nº 7.084/2010)

Questão IV - De que forma o aprimoramento dos Editais do PNLD pode contribuir para a melhoria do programa?

Questão V - Você acha que a formação acadêmica na área de História para o autor de Livro Didático participante do PNLD deveria ser uma exigência? Poderia auxiliar na melhoria de obras inscritas no processo de avaliação?

(Informe o Edital do PNLD a que se refere: ( 2008 ( ) 2011 ( ） 2014))

Questão VI - Qual seu nível de satisfação com relação aos instrumentos oferecidos (Decreto $n^{\circ} 7.084 / 2010$, Editais do PNLD, etc) para o processo de avaliação e seleção dos livros didáticos no âmbito do PNLD? 
(Informe o Edital do PNLD a que se refere: $(\quad$ ) 2008 （）2011 ( ） 2014))

Questão VII - O prazo disponibilizado pelo MEC é suficiente para um processo de avaliação e seleção de Livros Didáticos com qualidade?

Questão VIII - Descreva livremente sugestões para aprimoramento dos instrumentos avaliativos do Edital do PNLD. 


\section{ANEXO II}

Em um levantamento a respeito do perfil dos autores de livros didático de História que tiveram obras selecionadas incluídas no Guia do Livro Didático de História, obtivemos os dados referentes ao PNLD 2014, conforme quadro abaixo:

1. Quadro de dados sobre os autores de livros didáticos aprovados no PNLD 2014:

\begin{tabular}{|c|c|c|c|}
\hline \multicolumn{4}{|c|}{ AUTORES DE LIVROS DIDÁTICOS DE HISTÓRIA APROVADOS NO PNLD 2014} \\
\hline Livro/Obra Didática & Editora & Autor(es) & Formação Acadêmica* \\
\hline \multirow[t]{2}{*}{$\begin{array}{l}\text { Encontros com a História, } 3^{\text {a }} \\
\text { edição, } 2012 .\end{array}$} & \multirow[t]{2}{*}{ Positivo } & $\begin{array}{l}\text { Carla Maria J. } \\
\text { Anastasia }\end{array}$ & $\begin{array}{l}\text { Licenciada em Ciências } \\
\text { História (UFMG); Mestre } \\
\text { em Ciência Política } \\
\text { (UFMG); Doutora em } \\
\text { Ciências Humanas - } \\
\text { Ciência Política } \\
\text { (IUPERJ); }\end{array}$ \\
\hline & & Vanise Maria Ribeiro & $\begin{array}{l}\text { Licenciada em História } \\
\text { (FAC. De Filosofia } \\
\text { Ciências e Letras de } \\
\text { BH/MG); Especialização } \\
\text { em História do Brasil } \\
\text { (PUC-MG); }\end{array}$ \\
\hline $\begin{array}{l}\text { Estudar História: das origens do } \\
\text { homem à era digital, } 1^{\text {a }} \text { edição, } \\
2011 \text {. }\end{array}$ & Moderna & Patrícia Ramos Braick & $\begin{array}{l}\text { Mestre em História } \\
\text { (PUC-RS) }\end{array}$ \\
\hline \multirow[t]{2}{*}{$\begin{array}{l}\text { Coleção Link: História, } 4^{\mathrm{a}} \text { edição, } \\
\text { 2014. }\end{array}$} & \multirow[t]{2}{*}{ IBEP } & Denise Mattos Marino & $\begin{array}{l}\text { Licenciado em História } \\
\text { (FAC. De Filosofia, } \\
\text { Ciências e Letras de } \\
\text { Santos/SP); Mestre em } \\
\text { Educação (Universidade } \\
\text { Católica de Santos); }\end{array}$ \\
\hline & & Léo Stampacchio & $\begin{array}{l}\text { Bacharel em História } \\
\text { (PUC-SP); Mestre em } \\
\text { História do Brasil (PUC- } \\
\text { SP); }\end{array}$ \\
\hline \multirow[t]{3}{*}{$\begin{array}{l}\text { História e Vida Integrada, } 5^{\text {a }} \\
\text { edição, } 2012 .\end{array}$} & \multirow[t]{3}{*}{ Ática } & Nelson Piletti & $\begin{array}{l}\text { Licenciado em Pedagogia } \\
\text { (FAC. De Filosofia e } \\
\text { Letras de Guarulhos); } \\
\text { Livre-Docente FE USP; }\end{array}$ \\
\hline & & Claudino Piletti & $\begin{array}{l}\text { Licenciado em Pedagogia } \\
\text { (FAC.de Filosofia NSIC/ } \\
\text { RS); }\end{array}$ \\
\hline & & $\begin{array}{l}\text { Thiago Tremonte de } \\
\text { Lemos }\end{array}$ & $\begin{array}{l}\text { Licenciado em História } \\
\text { (PUC-SP); Mestre } \\
\text { História (PUC-SP); }\end{array}$ \\
\hline $\begin{array}{l}\text { História em documento, imagem } \\
\text { e texto, edição reformulada, } 2^{\mathrm{a}} \\
\text { edição, 2012. }\end{array}$ & FTD & \begin{tabular}{|l} 
Joelza Esther \\
Domingues
\end{tabular} & $\begin{array}{l}\text { Mestre em História Social } \\
\text { (PUC-SP); }\end{array}$ \\
\hline
\end{tabular}




\begin{tabular}{|c|c|c|c|}
\hline \multirow[t]{3}{*}{$\begin{array}{l}\text { História nos dias de hoje, } 1^{\mathrm{a}} \\
\text { edição, } 2012 .\end{array}$} & \multirow[t]{3}{*}{ Texto (Leya) } & Flávio de Campos & $\begin{array}{l}\text { Licenciado e Bacharel em } \\
\text { História (PUC-SP); }\end{array}$ \\
\hline & & \begin{tabular}{|l|} 
Regina Claro \\
\end{tabular} & $\begin{array}{l}\text { Bacharel em História } \\
\text { (USP); Mestre em } \\
\text { História Social (USP); }\end{array}$ \\
\hline & & Miriam Dolhnikoff & $\begin{array}{l}\text { Mestre em História } \\
\text { Econômica (USP); } \\
\text { Doutora em História } \\
\text { Econômica (USP); }\end{array}$ \\
\hline $\begin{array}{l}\text { História Sociedade \& Cidadania, } \\
\text { edição reformulada, 2a edição, } \\
2012 .\end{array}$ & FTD & Alfredo Boulos Júnior & $\begin{array}{l}\text { Mestre em História Social } \\
\text { (USP); Doutor em } \\
\text { História da Educação; }\end{array}$ \\
\hline \multirow[t]{2}{*}{$\begin{array}{l}\text { Jornadas. Hist - História, } 2^{\mathrm{a}} \\
\text { edição, } 2012 .\end{array}$} & \multirow[t]{2}{*}{$\begin{array}{l}\text { Saraiva Livreiros } \\
\text { Editores }\end{array}$} & Silvia Panazzo & $\begin{array}{l}\text { Bacharel em História } \\
\text { (PUC-SP); }\end{array}$ \\
\hline & & $\begin{array}{l}\text { Maria Luísa Albiero } \\
\text { Vaz }\end{array}$ & $\begin{array}{l}\text { Bacharel e Licenciada em } \\
\text { História (USP); Mestre } \\
\text { em História Social (USP); }\end{array}$ \\
\hline $\begin{array}{l}\text { Leituras da História, } 1^{a} \text { edição, } \\
2012 .\end{array}$ & \begin{tabular}{|l|} 
Edições Escala \\
Educacional \\
\end{tabular} & Oldimar Cardoso & $\begin{array}{l}\text { Mestre em Educação } \\
\text { (USP) }\end{array}$ \\
\hline \multirow[t]{2}{*}{$\begin{array}{l}\text { Novo História, Conceitos e } \\
\text { Procedimentos, } 3^{\text {a }} \text { edição, } 2012 .\end{array}$} & \multirow[t]{2}{*}{$\begin{array}{l}\text { Saraiva Livreiros } \\
\text { Editores }\end{array}$} & Ricardo Dreguer & $\begin{array}{l}\text { Bacharel e Licenciado em } \\
\text { História (USP); }\end{array}$ \\
\hline & & Eliete Toledo & $\begin{array}{l}\text { Bacharel e Licenciada em } \\
\text { História (USP); }\end{array}$ \\
\hline \multirow[t]{2}{*}{$\begin{array}{l}\text { Para entender a História, } 4^{\text {a }} \\
\text { edição, } 2012 .\end{array}$} & \multirow[t]{2}{*}{$\begin{array}{l}\text { Saraiva Livreiros } \\
\text { Editores }\end{array}$} & João Tristan Vargas & \begin{tabular}{|l|}
$\begin{array}{l}\text { Doutor em História } \\
\text { Social do Trabalho } \\
\text { (UNICAMP); }\end{array}$ \\
\end{tabular} \\
\hline & & $\begin{array}{l}\text { Divalte Garcia } \\
\text { Fiqueira }\end{array}$ & $\begin{array}{l}\text { Bacharel e Licenciado em } \\
\text { História (USP); }\end{array}$ \\
\hline \multirow[t]{4}{*}{$\begin{array}{l}\text { Para viver juntos História, } 3^{\mathrm{a}} \\
\text { edição, } 2012 \text {. }\end{array}$} & \multirow[t]{4}{*}{ Edições SM } & $\begin{array}{l}\text { Muryatan Santana } \\
\text { Barbosa }\end{array}$ & $\begin{array}{l}\text { Bacharel em História } \\
\text { (USP); Mestre em } \\
\text { Ciências (USP); }\end{array}$ \\
\hline & & \begin{tabular}{|l|} 
Débora Yumi \\
Motooka
\end{tabular} & $\begin{array}{l}\text { Bacharel em História } \\
\text { (USP); }\end{array}$ \\
\hline & & $\begin{array}{l}\text { Anderson Roberti dos } \\
\text { Reis }\end{array}$ & $\begin{array}{l}\text { Bacharel e Licenciado em } \\
\text { História (FMU); Mestre } \\
\text { em História } \\
\text { (UNICAMP); }\end{array}$ \\
\hline & & Ana Lúcia Lana Nemi & $\begin{array}{l}\text { Bacharel e Licenciada em } \\
\text { História (USP); Mestre } \\
\text { em História Social (USP); } \\
\text { Doutora em Ciências } \\
\text { Sociais (UNICAMP); }\end{array}$ \\
\hline \multirow[t]{2}{*}{$\begin{array}{l}\text { Perspectiva História, } 2^{\mathrm{a}} \text { edição, } \\
2012 .\end{array}$} & \multirow[t]{2}{*}{ Editora do Brasil } & Renato Mocellin & $\begin{array}{l}\text { Licenciado em Estudos } \\
\text { Sociais (UFPR); História } \\
\text { (UFPR); Especialização } \\
\text { História da Arte (PUC- } \\
\text { PR); Bacharel em Direito } \\
\text { (UFPR). }\end{array}$ \\
\hline & & Rosiane de Camargo & $\begin{array}{l}\text { Licenciada em História } \\
\text { (UFPR); Especialização } \\
\text { em Hist. Brasil (FAC. } \\
\text { Bagozi); }\end{array}$ \\
\hline $\begin{array}{l}\text { Por dentro da História, } 3^{\text {a }} \text { edição, } \\
2012 .\end{array}$ & $\begin{array}{l}\text { Edições Escala } \\
\text { Educacional }\end{array}$ & $\begin{array}{l}\text { Maria Aparecida } \\
\text { Pontes }\end{array}$ & $\begin{array}{l}\text { Licenciada em Pedagogia } \\
\text { (FMU) }\end{array}$ \\
\hline
\end{tabular}




\begin{tabular}{|c|c|c|c|}
\hline & & Célia Cerqueira & $\begin{array}{l}\text { Bacharel Biblioteconomia } \\
\text { (Unb) }\end{array}$ \\
\hline & & Pedro Santiago & $\begin{array}{l}\text { Bacharel em História } \\
\text { (USP) }\end{array}$ \\
\hline $\begin{array}{l}\text { Projeto Araribá História, } 3^{a} \\
\text { edição, } 2010 .\end{array}$ & Moderna & $\begin{array}{l}\text { Obra Coletiva, Editor } \\
\text { Responsável - Maria } \\
\text { Raquel Apolinário }\end{array}$ & $\begin{array}{l}\text { Bacharel e Licenciada em } \\
\text { História (USP); }\end{array}$ \\
\hline $\begin{array}{l}\text { Projeto Radix História, } 2^{\mathrm{a}} \text { edição, } \\
2012 .\end{array}$ & Scipione & Cláudio Vicentino & $\begin{array}{l}\text { Bacharel em Ciências } \\
\text { Sociais (USP); }\end{array}$ \\
\hline $\begin{array}{l}\text { Projeto Teláris História, } 1^{a} \\
\text { edição, } 2012 .\end{array}$ & Ática & Reinaldo Seriacopi & \begin{tabular}{|l|} 
Bacharel em Letras \\
(USP); Bacharel em \\
Comunicação Social \\
(Instituto Metodista de \\
Ensino Superior/ ABC) \\
\end{tabular} \\
\hline & & $\begin{array}{l}\text { Gislane Campos A. } \\
\text { Seriacopi }\end{array}$ & $\begin{array}{l} \\
\text { Licenciada em História } \\
\text { (PUC-SP); Mestre em } \\
\text { História (PUC-SP); }\end{array}$ \\
\hline $\begin{array}{l}\text { Projeto Velear História, } 1^{a} \\
\text { edição, } 2012 .\end{array}$ & Scipione & Roberto Catelli Junior & $\begin{array}{l}\text { Licenciado e Bacharel em } \\
\text { História (PUC-SP); } \\
\text { Mestre História } \\
\text { Econômica (USP); } \\
\end{array}$ \\
\hline & & Conceição Cabrini & $\begin{array}{l}\text { Licenciada em História } \\
\text { (PUC-SP); Bacharel em } \\
\text { Ciências Sociais (PUC- } \\
\text { SP); Mestre em } \\
\text { Jornalismo e Editoração } \\
\text { (USP); Doutora em } \\
\text { Comunicação e Semiótica } \\
\text { (USP); }\end{array}$ \\
\hline & & Andrea Montellato & $\begin{array}{l}\text { Bacharel em História } \\
\text { (PUC-SP); }\end{array}$ \\
\hline $\begin{array}{l}\text { Saber e fazer História, } 7^{\mathrm{a}} \text { edição } \\
2012 .\end{array}$ & $\begin{array}{l}\text { Saraiva Livreiros } \\
\text { Editores }\end{array}$ & Gilberto Cotrim & $\begin{array}{l}\text { Bacharel e Licenciado em } \\
\text { História (USP); Mestre } \\
\text { em Educação, Arte e } \\
\text { História da Cultura } \\
\text { (Universidade } \\
\text { Presbiteriana); } \\
\end{array}$ \\
\hline & & Jaime Rodrigues & $\begin{array}{l}\text { Bacharel em História } \\
\text { (USP); Doutor em } \\
\text { História (UNICAMP); }\end{array}$ \\
\hline $\begin{array}{l}\text { Vontade de saber História, } 2^{\mathrm{a}} \\
\text { edição, } 2012 .\end{array}$ & FTD & Adriana Dias & \begin{tabular}{|l|} 
Bacharel e Licenciada em \\
História (Universidade \\
Estadual de Londrina); \\
\end{tabular} \\
\hline & & Marco Pellegrini & $\begin{array}{l}\text { Bacharel em História } \\
\text { (Universidade Estadual } \\
\text { de Londrina); }\end{array}$ \\
\hline & & Keila Grinber & $\begin{array}{l}\text { Licenciada em História } \\
\text { (UFF); Doutra em } \\
\text { História (UFF); }\end{array}$ \\
\hline
\end{tabular}

Fonte: BRASIL, MEC. Guia dos Livros Didáticos - História - PNLD 2014, * Fonte: lattes.cnpq.br

A partir do quadro 1, começamos a realizar uma tipologia a respeito da origem curricular em nível de graduação e pós-graduação dos autores de livros didáticos de História que tiveram 
obras selecionadas incluídas no Guia do Livro Didático de História do PNLD 2014. Compusemos a tabela abaixo.

2. Tabela com a tipologia sobre os autores de livros didáticos aprovados no PNLD 2014:

Neste levantamento a respeito do perfil dos autores de livros didáticos de História que tiveram obras selecionadas e incluídas no Guia do Livro Didático de História, obtivemos os dados referentes ao PNLD 2014, conforme tabela abaixo.

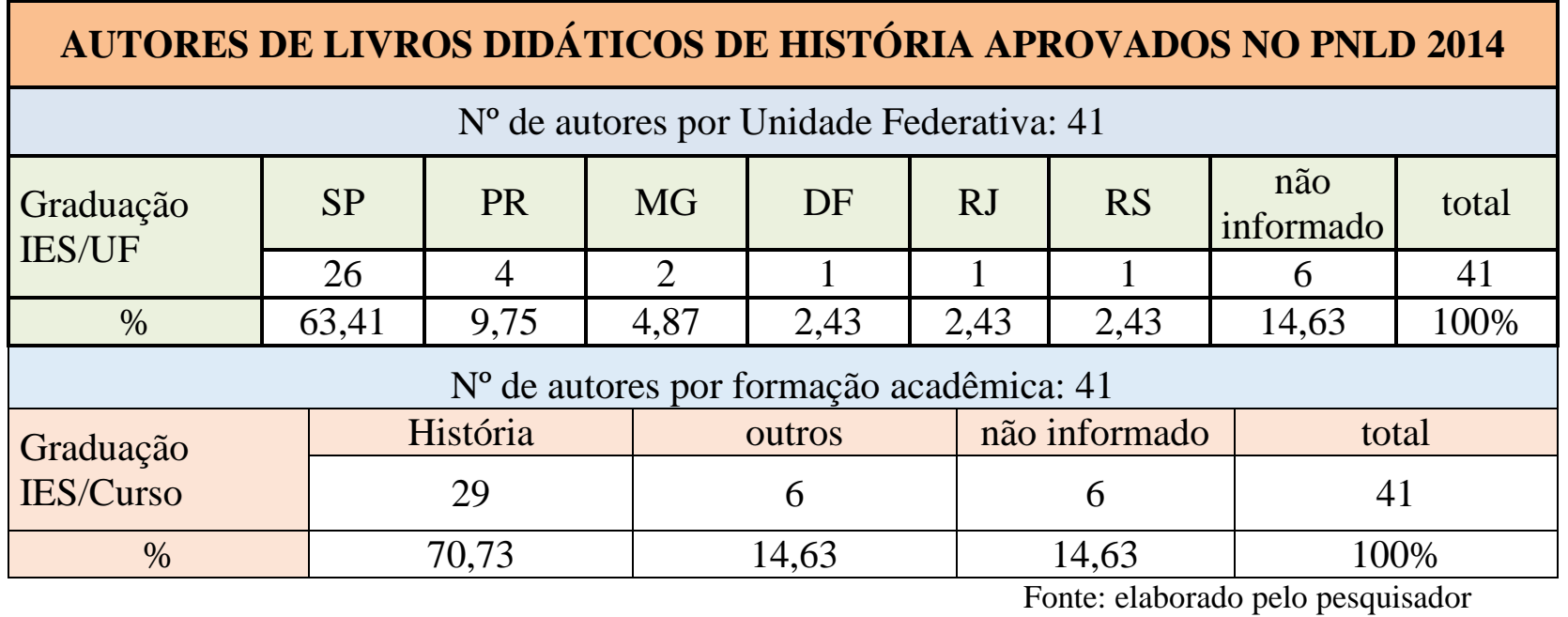

Observamos uma predominância de autores formados na Região Sudeste, com especial quantitativo de autores concentrados no Estado de São Paulo. 


\section{REFERENCIAL TEÓRICO}

BANDEIRA, Luiza, VIZEU, Rodrigo. Livros aprovados pelo MEC criticam FHC e elogiam Lula. Folha de São Paulo, Caderno: Poder. 01 de maio de 2011.

BATISTA, Antônio A. G. Recomendações para uma política pública de livros didáticos. Ministério da Educação. Secretaria de Educação Fundamental. Brasília: 2001.

BERUTTI, FLÁVIO; MARQUES, ADHEMAR. Ensinar e aprender história. Belo Horizonte: RHJ, 2009.

BRANDÃO, Nágela A; DIAS, Edmundo F. A questão da ideologia em Antonio Gramsci. In: Trabalho \& Educação, vol. 16, n 2, jul/dez. p. 82 - 98. 2007.

BRITO, Luiz Percival L. A sombra do caos: ensino de língua $x$ tradição gramatical. Campinas, SP: Mercado de letras: Associação de Leitura do Brasil, 1997.

CHAUI, Marilena. O que é ideologia. Coleção Primeiros Passos. 2.ed. Ed. Brasiliense. 1980. In: www.nhu.ufms.br. Digitalizado em 2004.

DEMO, Pedro. Educação e Qualidade. In: Coleção Magistério: formação e trabalho pedagógico. São Paulo: Papirus Editora. 1994.

FERREIRA, Marieta de M; FRANCO, Renato. Desafios do ensino de história. Estudos Históricos, Rio de Janeiro, vol. 21, n 41, janeiro-junho 2008. p. 79-93.

FILICE, Renísia Cristina Garcia. Raça e classe na gestão da educação da educação básica brasileira: a cultura na implementação de políticas públicas. Campinas: Autores Associados, 2011.

GALLO, Sílvio. Subjetividade, ideologia e educação. In: Perspectiva. Florianópolis, v. 16, n.29, p. $133-152$, jan/jun. 1998. 
GENTILI, Pablo A. Capítulo 4: O discurso da "qualidade" como nova retórica conservadora no campo educacional. In: Neoliberalismo, qualidade total e educação: visões críticas. Rio de Janeiro: Ed. Vozes, 1995.

GENTILI, Pablo A. A. Neoliberalismo e educação: manual do usuário. In: Escola S.A. Quem ganha e quem perde no mercado educacional do Neoliberalismo. CNTE, 1999.

GENTILI, Pablo A. A. (org.) e SILVA, Tomaz T. S. (org.) Capítulo 4: O discurso da "qualidade" como nova retórica conservadora no campo educacional in: Neoliberalismo, Qualidade Total e Educação: visões crítica. 12ª Edição, Editora Vozes Petrópolis, RJ. 2007. p. 111-177.

HOFLING, Eloisa de M. Notas para discussão quanto à implementação de programas de governo: Em foco o Programa Nacional do Livro Didático. Educação \& Sociedade, ano XXI, nº 70, p. 159-170, Abril/00.

KAMEL, Ali. O que ensinam às nossas crianças. O Globo, Arquivo de Artigos ETC. 18 de setembro de 2007.

MARX, Karl; ENGELS, Friedrich. A Ideologia Alemã. Editora Martin Claret. São Paulo, 1846.

MARX, Karl. A Questão Judaica. LusoSofia: press. 1989.

MUNAKATA, Kazumi. Dois manuais de história para professores: histórias de sua produção. Educação e Pesquisa, São Paulo, v. 30, n. 3, p. 51-529, set/ dez 2004.

NASSIF, Luiz. O Caso do livro no índex. Blog do Luiz Nassif. 20 de setembro de 2007.

NETTO, José Paulo. Introdução ao estudo do método de Marx. $1^{\text {a }}$ Edição. São Paulo: Expressão Popular, 2011.

OLIVEIRA, Margarida Dias de; STAMATTO, Maria I. S. (Org.) O livro didático: políticas educacionais, pesquisas e ensino. $1^{\text {a }}$ Edição. Natal: EDUFRN, 2007. 
PEREIRA, M. H.F; PEREIRA, A. C. I. Os sentidos do Golpe de 1964 nos livros didáticos de história (1970-2000): entre continuidades e descontinuidades. Setembro de 2009.

SAMPAIO, Francisco A. de Arruda; CARVALHO, Aloma Fernandes de. Com a palavra, o autor: em nossa defesa, um elogio à importância e uma crítica às limitações do Programa Nacional do Livro Didático. $1^{\text {a }}$ Edição. São Paulo: Editora Sarandi, 2010.

SILVA, Marco A. A Fetichização do Livro Didático no Brasil. Educação \& Realidade. Porto Alegre, v. 37, n. 3, p. 803-821, set/dez. 2012.

TERRAZZAN, Eduardo A; ZAMBON, Luciana B. Políticas de material didático no Brasil: organização dos processos de escolha de livros didáticos em escolas públicas de educação básica. Rev. Bras. Estud. Pedagog. (online), Brasília, v. 94, n 237, p; 585-602, maio/ago. 2013.

TRIVIÑOS, Augusto N. S. Introdução à pesquisa em Ciências Sociais: A pesquisa qualitativa em educação. $1^{\text {a }}$ edição, $18^{\text {a }}$ reimpressão. São Paulo, Atlas, 2009.

\section{PUBLICAÇÕES OFICIAIS}

BRASIL. Ministério da Educação. Secretaria de Educação Básica. Guia de livros didáticos PNLD 2014: História: ensino fundamental anos finais. Brasília: 2013. 152 p.

BRASIL. Ministério da Educação. Secretaria de Educação Básica. Guia de livros didáticos: PNLD 2011: História. Brasília: 2010. 120 p.

BRASIL. Ministério da Educação. Guia de livros didáticos PNLD 2008: História. Brasília: MEC, 2007. 154 p.

BRASIL, Ministério da Educação. Fundo Nacional de Desenvolvimento da Educação. Secretaria de Educação Básica. Edital de convocação para o processo de inscrição e avaliação de coleções didáticas para o Programa Nacional do Livro Didático/ PNLD 2014. Brasília: 2011. 
BRASIL. Ministério da Educação. Fundo Nacional de Desenvolvimento da Educação. Secretaria de Educação Básica. Edital de convocação para inscrição no processo de avaliação e seleção de coleções didáticas para o Programa Nacional do Livro Didático/ PNLD 2011. Brasília: 2008.

BRASIL. Ministério da Educação. Fundo Nacional de Desenvolvimento da Educação. Secretaria de Educação Básica. Edital de convocação para inscrição no processo de avaliação e seleção de obras didáticas a serem incluídas no Guia de Livros Didáticos para os Anos Finais do Ensino Fundamental/ PNLD 2008. Brasília: 2005.

BRASIL. Ministério da Educação. Secretaria de Educação Básica. Secretaria de Educação Continuada, Alfabetização, Diversidade e Inclusão. Secretaria de Educação Profissional e Tecnológica. Conselho Nacional de Educação. Câmara Nacional de Educação Básica. Diretrizes Curriculares Nacionais Gerais da Educação Básica. Brasília. 2013. 562 p.

\section{BIBLIOGRAFIA}

ARANHA, Maria L. A; MARTINS, Maria H. P. Filosofando: Introdução à Filosofia. 2. Ed. São Paulo: Moderna, 1993.

CHARTIER, Roger. Capítulo 5: Livros falantes e manuscritos clandestinos. As viagens de Dyrcona. In: Inscrever \& apagar. Cultura escrita e literatura. São Paulo. Editora Unesp, 2006. p. 163-203.

EVANS, Peter. O Estado como problema e solução. p. 107-156.

GALZERANI, M. C. B. e PINSKY, Jaime (org.) Belas Mentiras? A Ideologia nos Estudos sobre o Livro Didático In: O Ensino de História e A criação do fato. Coleção Repensando o Ensino. Editora Contexto, São Paulo, 1988. p. 105-109.

IASI, Mauro Luis. Capítulo III: Ideologia... Quero uma para viver? In: Ensaios sobre consciência e emancipação. $1^{a}$ Edição, Editora Expressão Popular. São Paulo, 207. p. 77-100. 
MICELI, Paulo e PINSKY, Jaime (org.) Por outras Histórias do Brasil in: O Ensino de História e A criação do fato. Coleção Repensando o Ensino. Editora Contexto, São Paulo, 1988. p. 31-42.

MOREIRA, Elizeu V. e CIAVATTA, Maria (org.) e REIS, Ronaldo R. (org.) A Teoria da qualidade total como Política educacional do Capital in: A pesquisa histórica em trabalho e educação. Liber Livro Editora, Brasília, 2010. p. 129-153.

NETTO, José P. Introdução ao estudo do método de Marx. Expressão Popular. São Paulo, 2011. 64 páginas.

MELO, Adriana A. S. Qualidade da educação no Brasil de hoje: projetos na mesa. In: Políticas de Gestão e Práticas Educativas - a qualidade do ensino. Brasília: Líber Livro, 2011.

NUNES, Edson. Cap. 2: Tipos de Capitalismo, Instituições e Ação Social. In: A Gramática Política do Brasil. Clientelismo e Insulamento Burocrático. Brasília. ENAP/Jorge Zahar Editor, 1997.

PINSKY, Jaime (org.) Nação e ensino de História no Brasil in: O Ensino de História e A criação do fato. Coleção Repensando o Ensino. Editora Contexto, São Paulo, 1988. p. 11-22.

SANTOS, Guilherme S. Capítulo I: O futuro da Era Vargas: o nascimento de um EstadoNação in: O ex-Leviatã brasileiro: do voto disperso ao clientelismo concentrado. Civilização Brasileira, Rio de Janeiro, 2006. P. 13-49.

SANTOS, Clóvis R. Capítulo 1: O curso de pedagogia e a formação dos profissionais da educação básica In: A gestão educacional e escolar para a modernidade. Cengage Learning, São Paulo, 2008. p. 1-19.

SCHMIDT, Maria A; e CAINELLI, Mariene. Ensinar História. In: Pensamento e ação no magistério. São Paulo: Scipione, 2004.

VALDEMARIN, Vera T. Capítulo 3; A produção de um repertório pedagógico: a Escola Nova e seus modos de uso in: História dos métodos e materiais de ensino: a escola nova e seus 
modos de uso. Biblioteca Básica da História da Educação Brasileira. Cortez Editora, São Paulo, 2010. p. 129-202.

VALDEMARIN, Vera T. Capítulo 4: O mesmo rumo, diferentes sentidos in: História dos métodos e materiais de ensino: a escola nova e seus modos de uso. Biblioteca Básica da História da Educação Brasileira. Cortez Editora, São Paulo, 2010. p. 203 -219. 